NBER WORKING PAPER SERIES

\title{
THE LENDING CHANNEL IN EMERGING ECONOMIES: ARE FOREIGN BANKS DIFFERENT?
}

\author{
Marco Arena \\ Carment Reinhart \\ Francisco Vázquez \\ Working Paper 12340 \\ http://www.nber.org/papers/w12340
NATIONAL BUREAU OF ECONOMIC RESEARCH 1050 Massachusetts Avenue
Cambridge, MA 02138
June 2006

The authors thank, without implicating, Gastón Gelos, Meral Karasulu, Liliana Rojas-Suárez, John Shea, Roland Straub, and participants at the Second Meeting of the Latin American Financial Network. The views expressed in this paper are those of the authors and do not necessarily reflect the views of the National Bureau of Economic Research, the International Monetary Fund, or the World Bank. The views expressed herein are those of the author(s) and do not necessarily reflect the views of the National Bureau of Economic Research.

(C2006 by Marco Arena, Carmen Reinhart and Francisco Vázquez. All rights reserved. Short sections of text, not to exceed two paragraphs, may be quoted without explicit permission provided that full credit, including (C) notice, is given to the source. 
The Lending Channel in Emerging Economics: Are Foreign Banks Different?

Marco Arena, Carmen Reinhart and Francisco Vázquez

NBER Working Paper No. 12340

June 2006

JEL No. E51, G21

\begin{abstract}
This paper assembles a dataset comprising 1,565 banks in 20 Asian and Latin American countries during 1989-2001 and compares the response of the volume of loans, deposits, and bank-specific interest rates on loans and deposits, to various measures of monetary conditions, across domestic and foreign banks. It also looks for systematic differences in the behavior of domestic and foreign banks during periods of financial distress and tranquil times. Using differences in bank ownership as a proxy for financial constraints on banks, the paper finds weak evidence that foreign banks have a lower sensitivity of credit to monetary conditions relative to their domestic competitors, with the differences driven by banks with lower asset liquidity and/or capitalization. At the same time, the lending and deposit rates of foreign banks tend to be smoother during periods of financial distress, albeit the differences with domestic banks do not appear to be strong. These results provide weak support to the existence of supply-side effects in credit markets and suggest that foreign bank entry in emerging economies may have contributed somewhat to stability in credit markets.
\end{abstract}

Carmen M. Reinhart

University of Maryland

School of Public Policy

Department of Economic

4105 Van Munching Hall

College Park, MD 20742

and NBER

creinhar@umd.edu 


\section{INTRODUCTION}

Foreign bank entry into emerging market economies has become an important component of financial globalization since the mid-nineties. Facilitated by financial liberalization and the need to recapitalize banking systems in the aftermath of financial crises, the volume of cross-border mergers and acquisitions (M\&As) targeting banks in emerging markets surged from about US\$6 billion between 1990-1996, to almost US $\$ 50$ billion—roughly one-third of the global amountbetween 1997-2000 (BIS 2004). The increase in foreign bank presence in emerging markets has been uneven, entailing significant changes in the structure of bank ownership in many recipient countries such as Mexico, where the share of banking system assets controlled by foreign institutions increased from 2 percent in 1990 to 82 percent in 2004.

The speed and depth of foreign bank entry has potentially important implications for financial and macroeconomic stability in recipient countries, and arguments have been made in both directions. On the one hand, it has been argued that foreign banks could play a stabilizing role on the supply of credit and deposits through upstream financing from their mother companies and reputation effects, particularly during periods of financial distress. On the other, foreign banks might be quick to pull out from emerging markets and could transmit external shocks into host countries. Empirical evidence on the implications of foreign bank entry for financial and macroeconomic stability in emerging markets, however, is limited to a paper by Dages, Goldberg, and Kinney (2000) analyzing the behavior of domestic and foreign banks in Mexico and Argentina during the Tequila crisis, and a paper by Detragiache and Gupta (2004), using data for Malaysia during the Asian crisis. Overall, these two papers find mild support to the first view. On the other hand, evidence from the 2002 crisis in Argentina seems to be more mixed, 
with some foreign banks opting to exit in the context of a broader international asset relocation, and others reducing their lending activities in line with the behavior of domestic banks.

At a more general level, the view that banks may play a non-trivial role in the transmission of shocks into credit markets, via supply-side effects, has received considerable attention in the literature of monetary policy transmission. Early work includes Bernanke and Blinder (1988), Kashyap, et al. (1993), Bernanke and Gertler (1995), Kashyap and Stein (1995). The basic idea is that financial constraints on banks impair their ability to offset negative shocks to deposits with alternative financing sources, generating supply-side effects in credit markets, and amplifying economic fluctuations. While the evidence seems to be broadly consistent with this proposal, identifying suitable proxies for unobserved financial constraints on banks has been a key challenge.

This paper builds on the idea that differences in bank ownership can serve as a proxy for unobserved financial constraints on banks, and combined with other observable bank characteristics (such as asset liquidity and capitalization) to identify changes in credit supply. To implement this, it uses a panel dataset of 1,565 banks in 20 Asian and Latin American countries during 1989-2001 and tests for systematic differences in the sensitivity of loans, deposits, and bank-specific lending and deposit rates, to various measures of monetary conditions, across domestic and foreign banks. It also looks for systematic differences in the behavior of domestic and foreign banks during tranquil times and periods of financial distress, exploiting various definitions of banking and currency crises available in the literature. The regions studied here are relevant to the issues at hand, as they endured several financial crisis during the 1990s. In 
addition, Latin America concentrated 48 percent of all cross-border M\&A targeting banks in emerging markets between 1991-2005, followed by Asia, with an additional 36 percent.

The results indicate that domestic and foreign banks behave roughly similarly along the dimensions considered, providing only weak support to the existence of supply-side effects in credit markets. In particular, loan and deposit growth are highly sensitive to economic activity, in a manner that does not differ significantly across domestic and foreign banks. At the same time, periods of tighter monetary conditions are associated with lower loan and deposit growth, with foreign banks displaying a somewhat lower sensitivity. This finding is driven by banks with relatively less liquid assets and/or lower capitalization, suggesting that it is not entirely attributable to potential differences in the characteristics of the borrowers and depositors of foreign banks. The results also show slight differences in the cross-sectional behavior of interest rates. Lending and deposit rates of foreign banks tend to react less during periods of financial distress. Taken together, these results indicate that foreign bank participation in emerging economies has not lead to increased instability in credit markets, and may have even played a beneficial effect.

The main contributions of the paper are as follows. First, it adds to the literature on the effects of foreign bank entry on financial stability, exploiting a comprehensive bank-level panel dataset that covers the main Latin American and emerging Asian countries during the nineties. The paper tracks the evolution of bank ownership by crossing the sample of banks with a complete list of mergers and acquisitions during the sample period. Second, it adds to the literature on the 
lending channel outside the United States, particularly in emerging markets $^{1}$ by exploiting differences in bank ownership to identify supply-side effects in credit markets. As a by-product, the paper provides a novel dataset on reserve requirements for the countries in the sample using information from central bank reports.

The rest of the paper is organized as follows. Section II places the paper in the context of the literature. Section III discusses the methodology and the hypotheses tested, as well as potential endogeneity problems and sources of bias. Section IV describes the data. Section V compares the response of selected financial variables (including loan growth, deposit growth, and bank-level lending and deposit rates) to various measures of monetary conditions, across domestic and foreign banks. Section VI focuses more closely on the response of loan growth to monetary conditions across domestic and foreign banks after splitting the sample by capitalization and liquidity levels. Section VII explores for systematic differences in the behavior of domestic and foreign banks during tranquil and crises periods. Section VIII concludes.

\section{RElATED Literature}

Most studies comparing the behavior of domestic and foreign banks in emerging economies focus on the efficiency effects of foreign bank entry. ${ }^{2}$ An incipient strand of the literature, to

\footnotetext{
${ }^{1}$ Studies in this area include: Edwards and Vegh (1997), who address the role of banks in the transmission of nominal shocks in Mexico and Chile, Agung (1998) who examines Indonesia, a volume edited by the BIS (1998) that looks at the lending channel in a sample of developing countries, and a cross-country study by Vázquez (2001).

2 The evidence seems to indicate that competitive pressures caused by foreign entry have led to improvements in banking system efficiency; for example, Barajas, Steiner, and Salazar (2000), Claessens and Glaessner (1999), Claessens, Demirgüç-Kunt, and H. Huizinga (2001), and Crystal, Dages, and Goldberg (2001).
} 
which this paper belongs, looks at the effects of foreign bank entry on financial stability and the response of credit markets to domestic and external shocks. Dages, Goldberg, and Kinney (2000) compared the behavior of bank lending across domestic and foreign banks in Mexico and Argentina during the Tequila crisis and concluded that foreign banks exhibited stronger and less volatile loans growth than domestic banks, but differences in asset quality, rather than ownership, appeared to be decisive in explaining the behavior of bank credit. Using data for Malaysia, Detragiache and Gupta (2004), found evidence that foreign banks with sufficient international diversification played a stabilizing role during the Asian crisis, while the behavior of foreign banks with operations concentrated in Asia was roughly similar to the behavior of domestic banks.

This paper is also related to the literature on the lending channel of monetary transmission, which focuses on the potential role of banks propagating shocks via loan-supply effects. The basic hypothesis is that capital market imperfections may prevent (at least some) banks from freely substituting away a negative shock to deposits with other sources of funding. In consequence, financially-constrained banks may optimally choose to cut lending in response to a shock to deposits, thereby affecting the availability of funds to bank-dependent firms. The chief obstacle in testing the lending channel is disentangling whether the response of credit to monetary shocks originates from loan demand - as implied by interest rate channels — or from changes in loan supply.

To get around the identification problem, empirical studies now generally resort to bank-level data, testing for cross-sectional differences in the response of bank lending to monetary shocks across banks with different degrees of financial constraints. Since financial constraints are not 
directly observable, they have been usually proxied by bank characteristics such as liquidity, size, and capitalization (for example, Jayaratne and Morgan (2000), Kishan and Opiela (2000), Kashyap and Stein (2000)). Financial constraints have been also proxied by bank ownership. Houston et al. (1997) explored the role of internal markets in banking in the U.S. and found that the loan growth of bank subsidiaries is sensitive to the financial position of their holding companies. A similar approach was implemented by Ashcraft (2000), who exploited a panel database of U.S. banks and used bank affiliation with multi-bank holding companies to proxy for financial constraints. In the international context, Peek and Rosengren (1997) looked at data on Japanese banks operating in the United States and found that binding risk-based capital requirements associated with the Japanese stock market decline of end-1980s translated into a decline in lending by their U.S. branches.

This paper follows a similar approach, exploiting the presence of internal capital markets as a source of cross-sectional variation between domestic and foreign banks. To the extent that foreign banks are less financially-constrained than domestic banks, comparing the sensitivity of loan growth to monetary conditions across domestic and foreign banks may identify supply-side effects in credit markets. This test, however, hinges on the validity of two assumptions. First, all else equal (i.e., capitalization, asset liquidity, and other bank characteristics), foreign banks have to be less financially-constrained than domestic, either because they can resort to funding from their parent institutions, or because they enjoy a more stable deposit base. Second, the loan demand facing domestic banks cannot be systematically different than the loan demand of foreign banks. 
This identification strategy is implemented with the use of bank-level fixed effects regressions, splitting the sample of banks between domestic and foreign with the use of a dummy variable. A baseline exercise compares the response of selected balance sheet components to monetary conditions across domestic and foreign banks, after controlling for changes in loan demand, proxied by GDP growth, and observable bank characteristics such as size, liquidity and capitalization. A second, more restrictive set of tests further explores systematic differences in the response of loan growth to monetary conditions across domestic and foreign banks, in the subsets of banks with lower liquidity and capitalization with respect to other banks in the same country. Lastly, a third test uses various definitions of currency, banking and debt crises and compares the behavior of domestic and foreign banks throughout crises and tranquil periods.

A few comments are convenient to place this paper in context. While the literature on the lending channel focuses on the role of banks in the transmission of monetary policy to the credit market, this paper takes a broader approach. It studies the effects of changes in monetary conditions on the credit market, regardless of whether changes are induced, or not, by monetary policy. This difference in emphasis is necessary since the paper focuses on emerging markets, where monetary conditions are typically affected by an open capital account. Consequently, monetary conditions here not only include money market rates, as usual in the lending channel literature, but also international interest rates and the change of the foreign exchange rate, exploiting the uncovered interest parity condition. The justification for the latter is straightforward, since currency depreciation increases the opportunity cost of holding bank deposits denominated in local currency, affecting their stability. Monetary conditions in this paper also include reserve requirements which are safely ignored in the lending channel literature as they are not longer 
used as a monetary policy tool in the United States. In contrast, reserve requirements as still are a commonly used policy instrument in many emerging markets. ${ }^{3}$

\section{Methodology}

A series of tests were implemented to explore the response of selected balance sheet and income statement components to changes in monetary conditions, across domestic and foreign banks, after controlling for some observable bank characteristics. More specifically, the tests comprised six separate specifications sharing the general form:

$$
y_{i, c, t}=\alpha_{i}+\sum_{s=1}^{r} \beta_{s} x_{c, t-s}+\rho z_{i, c, t-1}+\sum_{s=1}^{q} \delta_{s} m_{c, t-s}+u_{i t}
$$

where $i=1, \ldots, N$ refers to individual banks (panels), $c=1, \ldots, C$ to countries, and $t=1, \ldots, T_{i}$ to the time dimension (the sample is unbalanced, so $T_{i}$ varies across banks). The constants, $\alpha_{i}$, are the banklevel fixed effects.

Each specification used a different (bank-level) dependent variable, $y_{i c t}$. A first set of regressions employed quantity-related dependent variables: LOAN GROWTH, DEPOSIT GROWTH, the ratio of net LOANS TO DEPOSITS. A second set of regressions employed price-related dependent variables: LENDING RATES, DEPOSIT RATES, and LENDING MINUS DEPOSIT SPREADS. Loan and deposit growth were computed by first differencing the logarithm of the corresponding series, measured in constant (1995) local currency units. Bank-specific lending and deposit rates were estimated by combining information from income statements and balance sheets. Specifically, lending rates

\footnotetext{
${ }^{3}$ Reinhart and Reinhart (1999) provide a discussion of the use and effects of reserve requirements in a small open economy.
} 
were obtained by dividing interest revenues over average loan volume, and deposit rates were obtained by dividing interest expenses over average deposit volume. The spreads between lending and deposit rates were computed as the difference between these two. Admittedly, these variables are noisy indicators of the target series, as interest revenues include interests received from investments, while interest expenses are affected by interests paid on liabilities other than deposits. These, however, seem to be the best available indicators of bank-specific interest rates.

The vector $x$ contains country-level variables, aimed to control for changes in loan demand. Here the specification includes GDP GROWTH, also measured in 1995 local currency. The vector $z$ contains bank-level characteristics to control for financial constraints. Following a standard practice in the monetary transmission literature, three indicators were used: a measure of bank size, an indicator of asset liquidity, and an indicator of bank capitalization. Regarding bank size, the presumption is that bigger banks face lower external finance premiums and are thus better equipped to substitute away a negative shock to deposits with other sources of financing. To eliminate possible trends in bank SIZE, the estimation uses a relative measure, computed as the difference between the log of assets of a bank in a given year (in 1995 local currency) and the average computed over all banks in the same country and year:

$$
\text { Size }_{i, c, t}=\ln \left(\text { Assets }_{i, c, t}\right)-\frac{\sum_{i \in c} \ln \left(\text { Assets }_{i, c, t}\right)}{N_{c, t}}, \text { for } c=1, \ldots, C
$$

Where $N_{c t}$ stands for the number of banks in country $c$ in year $t$. Therefore, the resulting measure is a normalized variable with zero mean for each country and year. The second variable, asset 
LIQUIDITY, was computed as the proportion of liquid assets to total assets. ${ }^{4}$ The inclusion of this variable follows the presumption that banks with more liquid assets are better positioned to meet loan demand in the face of unexpected shocks to deposits. The third variable, CAPITALIZATION, was defined as equity capital over total assets. The presumption is that better-capitalized banks tend to pay lower risk premiums on non-insured debt and, therefore, face lower financing restrictions. These two variables were normalized with respect to the sample averages of each country. For example, the transformation applied to liquidity was:

$$
\text { Liquidity }_{i, c, t}=\text { Liquidity }_{i, c, t}-\frac{\sum_{t} \sum_{i} \text { Liquidity }_{i, c, t}}{N_{c}}
$$

Where $N_{c}$ is the number of observations in country $c$ over the whole period. Capitalization was treated similarly. Potential endogeneity problems and sources of bias associated with these variables are discussed below.

Going back to the specification, the vector $m$ contains two measures of monetary conditions. First, the evolution of liquidity in the banking system was captured by the interest rates on shortterm lending between financial institutions, MONEY MARKET RATES. Second, the evolution of required reserves was tracked with RESERVE REQUIREMENTS, an indicator variable constructed on the basis of central bank reports (see Appendix 1 to 3 for details). This indicator was allowed to vary on a scale from 1 to 5 , with a larger number indicating higher reserve requirements. ${ }^{5} \mathrm{~A}$

\footnotetext{
${ }^{4}$ Liquid assets include cash and reserves, government bonds, and other marketable securities.

${ }^{5}$ The indicator relied on judgment, as the structure of reserve requirements can be quite complicated (i.e., they can be defined on marginal vs. average deposits, and differentiated by deposit types).
} 
comparison between these two variables on a country-by-country basis suggests that they convey complementary information on monetary conditions (Figures 1 and 2).

As a robustness check, an alternative set of monetary conditions were used exploiting the uncovered interest parity. In particular, MONEY MARKET RATES were replaced by two variables: the yearly percent change of the average market exchange rate, DEPRECIATION, and the threemonth U.S. Treasury bill rate, T-BILL. The inclusion of these two variables follows from the fact that all countries studied here are small open economies, and the stability of bank deposits may be influenced by developments in the foreign exchange market.

In all the regressions, the target parameters are the coefficients of the monetary conditions (i.e., the $\delta$ 's). Differences across domestic and foreign banks were tested by interacting each explanatory variable with a dummy FOREIGN, which equals one for foreign banks and zero for domestic. An additional, more restrictive test was also implemented by further splitting the sample by bank characteristics. In particular, dummy variables were created to separate banks with lagged capitalization above the $75^{\text {th }}$ percentile with respect to the sample of banks operating in the same country. Similarly, another set of dummy variables was created to separate banks with lagged liquidity above the $75^{\text {th }}$ percentile with respect to the rest of banks in the same country. As a by-product, the coefficients associated with GDP growth (the $\beta$ 's) also allow to explore for systematic differences in the cyclical behavior of the selected endogenous variables, across domestic and foreign banks.

Separate regressions were estimated for Asia and Latin America on the notion that differences in macroeconomic performance and banking practices between these two regions render the population parameters different. It is well recognized, for example, that foreign bank entry into 
emerging markets has led to the emergence of "regional evolvers", that is, banks that use their relative advantages in a region (i.e., historic and cultural links with host countries) to focus their international expansion, as in the case of Spanish banks in Latin America and Japanese banks in East Asia.

\section{A. Expected Results}

Consider the set of regressions dealing with quantity-related endogenous variables (i.e., loans and deposits). The first specification provides a test for the sensitivity of LOAN GROWTH to changes in monetary conditions. Under the lending channel hypothesis, financially-constrained banks are expected to be more sensitive to monetary conditions, implying that the coefficients associated with domestic banks are higher in absolute value (i.e., more negative) than those for foreign banks. The second specification further explores for differences in the sensitivity of DEPOSIT GROWTH to monetary conditions across domestic and foreign banks. If banks have the capacity to adjust their deposit rates to partially offset a negative shock to deposits, the lending channel hypothesis would imply a lower sensitivity of deposits to monetary conditions for more financially-constrained banks - as they are less capable to substitute them with other sources of funds. The third specification is a combination of the previous two. It checks for the sensitivity of LOAN TO DEPOSIT ratios to changes in monetary conditions. The lending channel hypothesis implies that the associated coefficient has to be non-significant for more financially-constrained banks, and positive for less financially-constrained banks, since the later would tend to finance a lower proportion of loans with customer deposits in response to tighter monetary conditions. 
Consider now the models with price-related endogenous variables (i.e., deposit rates, lending rates, and lending minus deposit spreads). The lending channel hypothesis implies that financially-constrained banks display a larger response of lending and deposit rates to monetary conditions. Moreover, the lending minus deposit spread is expected to increase under tighter monetary conditions for financially-constrained banks. This is because, in response to a negative shock to deposits, banks would try to resort to alternative forms of financing, increasing their premium on non-insured debt and, by cost minimization, their equilibrium deposit rates. This increase would tend to be translated more than proportionally into lending rates due to the taxlike effect of reserve requirements on insured deposits and the cost of maintaining precautionary liquid assets.

\section{B. Sources of Bias and Endogeneity Problems}

As with any reduced-form estimations, there are potential endogeneity problems and bias associated with the use of bank characteristics (i.e., size, liquidity, and capitalization). Regarding size, there is possible joint determination since a bank may actually become larger precisely because of large deposit (and loan) growth. Regarding capitalization, a financially-constrained bank may choose to be more capitalized, eroding the usefulness of this indicator as a measure of financial constraints. In fact, as shown below, balance sheet data indicates that capitalization decreases systematically with bank size, suggesting that it may be a poor indicator of financial constraints on banks. A similar problem arises with the use of liquidity ratios. A bank may optimally choose to have a more liquid asset structure to compensate for higher financial constraints. Again, it is unclear whether a less liquid asset structure is a clear-cut indicator of 
higher financial constraints. To reduce these endogeneity problems, the regressions use lagged values of bank-level characteristics.

A related problem, spurious correlation induced by mean-reversion may arise from the use of liquidity ratios as defined. To see why, suppose that bank assets are composed only of liquid instruments and loans. In this simplified balance sheet, a bank with higher-than-average liquid assets in period $t-1$ will tend to display a higher-than-average loan growth in year $t$. Thus interacting monetary conditions with a liquidity indicator will tend to erode the power of the test, biasing the results in favor of the lending channel hypothesis (i.e., banks with more liquid balance sheets having a lower sensitivity of loan growth to monetary disturbances). This problem can be avoided by choosing a different scaling variable. For example, liquid assets could be scaled by total deposits, which in fact seems to be the relevant measure if deposits are the main source of shocks to bank's liabilities. For comparative purposes, this paper computes liquidity in the usual way (scaling liquid assets by total assets), but an additional exercise was implemented using deposits as the scaling variable with similar qualitative results.

\section{DATA}

Macro data come from the International Financial Statistics. The series include MONEY MARKET RATES (series 60b), the yearly percent change of the average market exchange rate, DEPRECIATION (series rf), the three-month U.S. Treasury bill rate, T-BILL (series 11160c), and 
GDP GROWTH (series 99b), expressed in constant (1995) local currency units using consumer price indexes (series 64). ${ }^{6}$

Bank-level data (i.e., financial statements) come from the Bankscope database. Series are yearly, covering a sample of 1,565 banks in 20 countries during 1989-2001. The sample of countries includes all major Latin American and Southeast Asian countries. ${ }^{7}$ Comparing the behavior of domestic and foreign banks in this sample offers a rich experiment, since it covers pre- and postentry years, as well as several banking and balance of payment crisis. In total, the sample has 8,574 observations, distributed across time and countries as shown in Table 1 . The decrease in the number of banks in Asia after 1997 reflects the consolidation process following the Asian crisis.

Using the Bankscope database has two major advantages. First, the coverage is fairly comprehensive, with sampled banks accounting for about 90 percent of total assets in each country, according to the source. Second, the accounting information at the bank level is presented in standardized form, after making adjustments for differences in accounting and reporting standards across countries. On the other hand, the data has some limitations. First, there is a sample-selection bias in favor of large banks which weakens somewhat its usefulness, as small banks may tend to be more financially constrained than large banks. Second, the data do

\footnotetext{
${ }^{6}$ For countries with incomplete or unavailable information on money market rates, an alternative indicator was used. Deposit rates (series 60L) were used for Bolivia, Chile, Colombia, Panamá, Paraguay, and Venezuela; the call money rate (series 60) was used for India; the one-month average interbank offer rate for Hong Kong; and the interbank rate for Taiwan.

${ }^{7}$ For Latin America, the list of countries includes: Argentina, Bolivia, Brazil, Chile, Colombia, Mexico, Panama, Paraguay, Peru, Uruguay, and Venezuela. For East Asia: Hong Kong, India, Indonesia, South Korea, Malaysia, Philippines, Singapore, Thailand, and Taiwan.
} 
not provide a breakdown of loan portfolios by sectors or by borrower types, precluding the use of controls for bank-specific changes in loan demand. Third, the data do not provide information on the currency composition of loans and deposits, which could be a potentially useful source of cross-sectional variation in the open economy context.

While in many cases Bankscope reports both consolidated and unconsolidated financial statements, this paper uses unconsolidated figures to the extent possible, to reduce variations arising from changes in subsidiaries' ownership and to work with comparable accounting data. From the original source, unconsolidated figures were available in all but 73 cases. For the purposes of the exercises below, balance sheet figures were converted into constant 1995 local currency using consumer price indexes (series 64 of the IMF: International Financial Statistics). Series in constant 1995 US\$ were also computed using the average market exchange rate for each country (series rf of the IMF: International Financial Statistics).

Outliers were identified through the application of several filters, including limits on the yearly change in total assets, on the yearly growth rate of loans and deposits, and on the ratio of net loans to deposits. Few cases with other data deficiencies and with negative equity were also removed. ${ }^{8}$

\footnotetext{
${ }^{8}$ Specifically, the following filters were used. First, 31 observations where yearly asset growth in constant US\$ exceeded 200 percent in absolute terms were removed. Second, 57 cases where the yearly loan growth exceeded 300 percent in absolute terms, and 77 cases where the yearly deposit growth exceeded 300 percent in absolute terms were also removed. Third, 27 cases where loans represented more than 100 times the value of deposits were removed. Finally, 66 cases with negative deposits and 94 cases with negative equity capital were also removed. In total, 316 observations were eliminated, as some of the filters affected the same observations.
} 
The identification of foreign banks in each country was achieved through several complementary steps aimed to minimize misclassifications. A bank was classified as "foreign" in a given year if it had at least 51 percent of its capital in the hands of residents of industrial OECD countries (i.e., excluding Mexico and Korea). The ownership structure at the end of 2001, for each bank in the sample, was obtained from Bankscope and from central banks. To reconstruct backwards the chronological evolution of ownership throughout the period, the list of banks was intersected with a comprehensive list of mergers and acquisitions targeting financial institutions in the sampled countries (a detailed description is given in Appendix 4). Due to data limitations, no distinction was made between subsidiaries and branches of foreign banks - an otherwise relevant separation, to the extent that subsidiaries' access to capital from their parent institutions may not be automatic, as in the case of branches.

Descriptive evidence on the structure of balance sheets across regions and bank sizes is presented in Table 2. No clear patterns arise in the balance sheets of banks operating in Latin America. On the other hand, banks operating in Asia display some regularities similar to those reported in Kayshap and Stein (1994). In particular, larger banks tend to have a higher proportion of loans to assets, and they rely more on non-deposit financing, and less on equity. These patterns have been interpreted as consistent with the presence of imperfect substitution between deposits and other sources of financing, especially for smaller banks. If small banks cannot completely offset shocks to deposits with other financing sources, they will optimally hold a buffer stock of liquid assets to reduce the costs of early loan liquidation. In equilibrium, they will also tend to rely less in non-deposit financing and more on internal capital. 
This presumption can be further checked by splitting the sample across domestic and foreign banks. Foreign banks could be more aggressive in lending if they have access to internal financial resources from their mother institutions. Also, they could have systematic differences in the liability structure of their balance sheets with respect to domestic banks. Table 3 presents summary statistics on loan growth, deposit growth, and several indicators of the structure of balance sheets for domestic and foreign banks, and by regions. On average, foreign banks in Latin America have higher rates of deposit and loan growth than domestic banks, but the opposite holds true for Asia. In general, there are not strong differences in the structure of balance sheets structure across domestic and foreign banks, so the data does not seem to fit into the hypothesized pattern.

\section{BASELINE RESUlts}

The results of baseline regressions for the Asian and Latin American sub-samples are presented in Tables 4 and 5. Given the nature of the data, which combines a cross-section and a time-series dimension, the equations were estimated with Generalized Least Squares (GLS) to accommodate possible autocorrelation within panels and heteroscedasticity across panels. The estimation allowed for panel-specific AR(1) processes. Cross-sectional correlations between panels were not considered since the number of panels is much larger than the time series dimension.

For each sub-sample, six regressions were computed, using identical specifications except for the dependent variables. Those presented in the first three columns are quantity-related (LOAN GROWTH, DEPOSIT GROWTH, and LOAN TO DEPOSIT ratios), and those in columns four to six are price-related (LENDING RATES, DEPOSIT RATES, and LENDING MINUS DEPOSIT spreads). To facilitate reading, the explanatory variables are divided in two panels. The upper panel includes 
GDP GROWTH and the bank-level controls, while the lower panel groups the monetary conditions. To compare the responses across domestic and foreign banks, all the explanatory variables were interacted with a dummy variable, FOREIGN, which equals one for foreign banks and zero otherwise. Robust standard errors are reported in square brackets.

In the first two columns, the results show that loan and deposit growth tend to be highly procyclical (especially the former), with no statistically significant differences across domestic and foreign banks. A similar result was obtained in Dages, Goldberg and Kinney (2000) for Mexico and Argentina. In addition, banks with higher asset liquidity or capitalization at the end of the previous year tend to display stronger loan growth, with some indication that the response is larger among the subset of foreign banks. Going to the lower panel, loan growth decelerates in response to tighter monetary conditions, with some support for the view that loan growth of foreign banks tends to be less sensitive to changes in money market rates. Interestingly, the results in the third column indicate that loans and deposits move one-for-one at the one year frequency, independently of the economic cycle, monetary conditions, and bank characteristics, including ownership.

Going to columns four to six, the upper panel shows that deposit rates tend to be countercyclical, with some evidence suggesting that this is less intense in the case of foreign banks in the Asian sub-sample. Banks with higher liquidity tend to pay lower deposit rates and also charge lower interest spreads, a result that appears to be mainly attributable to changes in lending rates. However, no significant differences arise between domestic and foreign banks. In the lower panel, periods of tight monetary conditions are associated with higher lending and deposit rates, with inconclusive results in terms of spreads (for example, spreads go up for the Latin American 
sub-sample, and decrease for the Asian sub-sample). In the Asian sub-sample, foreign banks tend to display a lower sensitivity of lending and deposit rates to changes in monetary conditions.

Overall, the results tend to provide only weak support to the lending channel hypothesis. In particular, loan growth of foreign banks is less sensitive to money market rates in both Asia and Latin America, and some evidence suggests that deposits on foreign banks are also less sensitive to monetary conditions (in the Latin America sub-sample). On the other hand, the results show no statistically significant differences in the response of loan growth to changes in reserve requirements across domestic and foreign banks. All these results were qualitatively robust to the removal of 58 banks changing ownership during the period.

\section{A Closer Look to LoAn Growth}

This section focuses more closely on the response of loan growth to monetary conditions given its importance in the monetary transmission mechanism. The regressions parallel those presented before, but adding interacting terms between bank ownership and other bank characteristics. In particular, besides partitioning the sample across domestic and foreign banks, the sample was first split by capitalization, separating banks with capitalization above (and below) the $75^{\text {th }}$ percentile with respect other banks operating in the same country. ${ }^{9}$ Second, the sample was split by asset liquidity, separating banks above (and below) the $75^{\text {th }}$ liquidity percentile with respect to other banks operating in the same country. Subject to the caveats discussed above, banks with stronger capitalization and more liquid assets could be considered to be less financially-

\footnotetext{
${ }^{9}$ In other words, the percentiles of capitalization were computed on a country-by-country basis, and the sample was partitioned between banks above (and below) the $75^{\text {th }}$ percentile.
} 
constrained, and therefore better equipped to isolate loan growth from changes in monetary conditions. Therefore, the differences between domestic and foreign banks reported before are expected to be larger in the sub-samples of banks with lower liquidity and/or capitalization.

Summary results of three sets of regressions, using LOAN GROWTH as dependent variable, are presented in Tables 6 and 7. To facilitate the reading, the only coefficients reported are those associated with the monetary conditions (i.e., MONEY MARKET RATE and RESERVE REQUIREMENTS). The upper panel displays the results of the regressions covering the whole sample (and are therefore identical to those presented before). The regression in the middle panel splits the sample by bank ownership and capitalization, and the regression in the lower panel splits the sample by bank ownership and liquidity. Each panel displays the coefficients of domestic banks alongside the matching coefficients for foreign banks, and the p-values for the null(s) of coefficient equality between square brackets.

Going to the upper panel, the coefficients associated with the money market rate are statistically significant and have the expected (negative) sign for domestic banks, but are not different from zero in the case of foreign banks. As discussed before, the null of coefficient equality across domestic and foreign banks can be rejected in both the Latin American and the Asian subsamples. The results in the two lower panels indicate that loan growth of banks with lower capitalization and/or liquidity tend to be more sensitive to changes in money market rates in the two sub-samples. While this applies to both domestic and foreign banks, the coefficients of the latter are not significantly different from zero in most cases. A stricter comparison indicates that the null of coefficient equality across domestic and foreign banks can be rejected only when the sample is partitioned by liquidity, but not by capitalization, with the evidence providing some 
support to the lending channel hypothesis. On the other hand, a look at the coefficients associated with reserve requirements indicates that, while they have the expected negative sign, their standard errors are too large and the null of coefficient equality between domestic and foreign banks cannot be rejected in most cases.

As a complementary exercise, parallel regressions were computed using an alternative set of indicators of monetary conditions. The new set also included reserve requirements, but replaced money market rates with the nominal exchange rate depreciation and international interest rates (proxied by the federal funds rate). The results, presented in Tables 8 and 9 are roughly comparable to those reported above, providing some evidence in support of the lending channel hypothesis. In both sub-samples, loan growth decelerates with exchange rate depreciation, with foreign banks generally displaying a lower sensitivity. Moreover, the differences appear to be driven by less liquid and/or less capitalized banks.

The coefficients associated with reserve requirements and the federal funds rate are less conclusive. For the Latin American sub-sample both coefficients have the expected (negative) sign but the standard errors are too high to be conclusive, and there are no significant differences across domestic or foreign banks. For the Asian sub-sample, foreign banks display a larger sensitivity to reserve requirements than domestic, which runs contrary to expectations, while the coefficients of the federal funds rate are either not significant or have the wrong sign. Similar results were obtained using the money market rates of Japan and Australia as alternative measures of international interest rates, possibly reflecting the fact that Asian countries were mostly non-reliant on foreign capital inflows. 
Summing up, the results indicate that loan growth of well capitalized and/or more liquid banks is less sensitive to changes in monetary conditions. While in most cases the differences between domestic and foreign banks are not statistically significant, a few exceptions tend to support the lending channel hypothesis.

The results obtained so far implicitly assume that the behavior of domestic and foreign banks is regular during tranquil times and during periods of financial distress. Differences in the behavior of domestic and foreign banks (and their depositors), however, could be magnified during periods of financial distress. The next section provides a closer look into this.

\section{Are Foreign Banks Different During Crisis Periods?}

A related comparison between domestic and foreign banks can be performed by separating tranquil periods and episodes of financial distress. Arguably, the latter entail larger financial constraints on banks, as well as changes in depositors' behavior that may induce relocations of deposits toward larger or sounder banks. Therefore, potential asymmetries in financial constraints across domestic and foreign banks would tend to increase during crises periods, especially if foreign banks are perceived as safer than domestic. The sample of countries included in this study offers a rich information set to address this issue, since half of them undergo some type of financial crisis during the nineties.

To implement this exercise, three types of (related) crises are considered: currency, banking, and debt crises. The definitions of each type of crises, and the series, are borrowed from previous studies. A first exercise exploits the currency and banking crises defined in Kamisnsky and 
Reinhart (1999), ${ }^{10}$ and the debt crises provided in Detragiache and Spilimbergo (2001). ${ }^{11}$ As in the original series, each crisis variable is a dummy that takes the value of one at the crisis year and zero elsewhere.

A first pass at the evidence is provided with the help of a set of crisis windows spanning three years and centered around banking, currency, or debt crisis. The close relationship between these three types of crises — both within and between countries — tends to produce clustering, and therefore the size of the window exceeds the three-year period in many countries. For example, the Mexican currency crisis of 1994 was preceded by a banking crisis in 1992, and therefore the associated crisis window spans over five years (1991-1995). Similarly, the Venezuelan currency crisis of 1994-1995 was preceded by a banking crisis that started in 1993, and thus the crisis window also spans over five years (1992-1996). In other cases, such as Malaysia and Philippines during the 1997 Asian Crisis, the currency and banking crises occurred simultaneously, and the crisis window covers three years (1996-1998).

\footnotetext{
${ }^{10}$ In Kaminsky and Reinhart (1999), the dating of currency crises is based on an index of currency market turbulence, computed as a weighted average of exchange rate changes and reserve changes. A currency crisis occurs when the index reaches (or surpasses) three standard deviations above the mean. In turn, (the beginning of) a banking crisis is defined by two types of events: (i) bank runs that lead to the closure, merging, or takeover by the public sector of one or more financial institutions; or (ii) if there are no runs, the closure, merging, takeover, or largescale government assistance of an important financial institution (or group of institutions) that marks the start of a string of similar outcomes for other financial institutions.

${ }^{11}$ In Detragiache and Spilimbergo (2001), a debt crisis occurs when either (or both) of the following conditions occur: (i) there are arrears of principal or interest on external obligations towards commercial creditors (banks or bondholders) of more than 5 percent of total commercial debt outstanding; (2) there is a rescheduling or debt restructuring agreement with commercial creditors as listed in the Global Development Finance (World Bank Debt Tables).
} 
Figure 3 presents the behavior of loan growth across domestic and foreign banks for each country, both during crises and tranquil periods. ${ }^{12}$ The graphs illustrate two results. First, not surprisingly, loan growth decreases sharply at the beginning of the crisis window and tend to recover toward the end. Second, the behavior of loan growth across domestic and foreign banks is remarkable similar, even during periods of financial distress .

A more systematic test comparing the behavior of domestic and foreign banks across crises and tranquil periods was performed by running panel regressions with bank-level fixed effects, and splitting the sample of banks between domestic and foreign with the use of a dummy variable. The results, presented in Tables 10 and 11 are qualitatively similar for the Asian and Latin American sub-samples. The first two columns indicate that both loan and deposit growth decrease during crises periods, with mild or not significant differences between domestic and foreign banks, with the exception of deposit growth in Asia, which shows a larger contraction for the subset of foreign banks. The third column, which uses the ratio of loans to deposits as dependent variable, indicates that the proportion of loans financed though deposits remains roughly constant during crises periods. In other words, changes in loans are matched one-for-one by changes in deposits both during crises and tranquil periods, and this tends to apply equally to domestic and foreign banks.

Interestingly, differences across domestic and foreign banks during crises periods appear to be related to the behavior of interest rates. The regressions presented in the fifth and sixth columns indicate that bank-specific deposit and lending rates increase during crises periods, with a

\footnotetext{
${ }^{12}$ Loan growth was computed as the median taken over all banks operating in the same country in a given year.
} 
smoother patterns for foreign banks. The behavior of bank spreads during crises periods, however, is less conclusive, and the results in all cases show no differences between domestic and foreign banks.

A potential drawback of these results is that they are obtained from a crisis window that may be too large, as differences in the behavior of domestic and foreign banks may tend to disappear as the size of the crisis window increases. To take this into account, the same regressions were computed again using a slightly richer set of crisis variables. Specifically, three yearly dummy variables were created to isolate potential differences in bank behavior around crisis episodes. The first variable, CRISIS T-1, equals one for the year preceding the crisis and zero elsewhere, the second, CRISIS T, equals one in the year of the crisis and zero elsewhere, and the third, CRISIS $\mathrm{T}+1$, equals one for the year immediately after the crisis and zero elsewhere. The behavior of domestic and foreign banks around, and during crisis periods, was then compared.

The results displayed in the first two columns of Tables 12 and 13 indicate both loan growth and deposit growth tend to be slightly above average in the year preceding the onset of the crises, and sharply collapse immediately after, with mild evidence indicating a less pronounced decline of credit in the case of foreign banks operating in Latin America, but the opposite in Asia. Looking at the third column, the ratio of loans to deposits tends to decrease during and after crises episodes, but the differences with tranquil periods tend to be insignificant. In other words, the data strongly indicates that loans and deposits of both domestic and foreign banks move one-toone during tranquil and crises periods.

Going to the last three columns, lending rates increase above average one year before the crises, and remain high thereafter (within the crises window considered). Deposit rates, on the other 
hand, appear to react more sluggishly, since they do not increase significantly during the year preceding the crises.

To check the sensitivity of the results, the regressions were computed again using two alternative definitions of banking crises: Frankel and Rose (1996), and Caprio and Kinglebiel (1996). Summary results of these regressions, provided in Tables 14 and 15, support the previous conclusions, in the sense that no systematic differences in loan and deposit growth arise between domestic and foreign banks, regardless of the operational definition of crises employed. On the other hand, the behavior of deposit and lending rates across domestic and foreign banks tends to differ during crises periods, with foreign banks displaying, in general, a somewhat lower sensitivity to market conditions.

\section{CONCLUdING REMARKS}

The increase of foreign bank presence in emerging markets has generated debate on its potential effects on financial stability and the transmission of domestic and external shocks into credit markets. The results reported in this paper tend to fall on neutral grounds. There is some evidence that loan growth of foreign banks is less sensitive to changes in monetary conditions in host countries, a result driven by banks with lower asset liquidity and/or capitalization. Among the group of banks with stronger balance sheets, however, there is a strong similarity in the response of loans and deposits to monetary conditions across domestic and foreign banks. These findings offer some evidence supporting the existence of supply-side effects in credit markets, provided that differences in bank ownership are a good proxy for financial constraints on banks, and that no systematic differences arise in loan demand across domestic and foreign 
banks. While the latter may be unlikely, the fact that the differences are driven by less liquid and/or less capitalized banks offers an additional support.

At a more general level, the results indicate that foreign bank participation in emerging markets has not led to increased instability in credit markets. The response of credit to economic activity and monetary conditions seems to be roughly similar across domestic and foreign banks. Differences, if any, appear to be more closely related to the behavior of interest rates. In particular, deposit and lending rates of foreign banks tend to be less sensitive to changes in monetary conditions, and smoother during periods of financial turmoil in host countries, which suggest that foreign banks may have an advantage over their domestic peers in attracting deposits. 


\section{REFERENCES}

Agung, J. (1998), "Financial Deregulation and the Bank Lending Channel in Developing Countries: the Case of Indonesia," Asian Economic Journal, Vol. 12, No. 3, pp. 273-294.

Ashcraft, A. (2000). "New Evidence on the Lending Channel." mimeo, Department of Economics, MIT.

Barajas, A., R. Steiner, and N. Salazar (2000). "Foreign Investment in Colombia's Financial Sector." Journal of Development Economics, Vol 63, pp. 157-196.

Bernanke, B. and A. Blinder (1988), "Credit, Money and Aggregate Demand," The American Economic Review, Vol. 78, 2, pp. 435-439.

Bernanke B. and M. Gertler (1995), "Inside the Black Box: The Credit Channel of Monetary Policy Transmission," The Journal of Economic Perspectives, Vol. 9, 4, pp. 27-48.

Bank of International Settlements (1998), "The Transmission of Monetary Policy in Emerging Market Economies”, BIS Policy Papers 3, January.

Bank of International Settlements (2004), "Foreign Direct Investment in the Financial Sector of Emerging Market Economies", report submitted by a working group established by the Committee on the Global Financial System, March,

Caprio, G., and D. Klingebiel, (1996), "Bank Insolvencies, Cross-Country Experiences.” World Bank Policy Research Paper 1620.

Claessens, S., and T. Glaessner (1999). "Internationalization of Financial services in Asia." World Bank WP 1911.

Claessens, S., A. Demirgüç-Kunt, and H. Huizinga (2001). "How Does Foreign Presence Affect Domestic Banking Markets?” Journal of Banking and Finance, Vol. 25, 5, pp. 891-911.

Crystal, J., G. Dages, and L. Goldberg (2001). "Does Foreign Ownership contribute to Sounder Banks in Emerging Markets? The Latin American Experience.” Federal Reserve Bank of New York.

Dages, B., L. Goldberg, and D. Kinney (2000). "Foreign and Domestic Bank Participation in Emerging Markets: Lessons from Mexico and Argentina.” Economic Policy Review, Federal Reserve Bank of New York, Vol. 6, 3, pp. 17-36.

Detragiache, E., and P. Gupta (2004), "Foreign Banks in Emerging Market Crises: Evidence from Malaysia.” IMF Staff Working Papers WP/04/129.

Detriagache, E., and A. Spilimbergo, (2001), "Crises and Liquidity: Evidence and Interpretation.” IMF Staff Working Papers WP/01/2.

Edwards, S. and C. Végh (1997), "Banks and Macroeconomic Disturbances Under Predetermined Exchange Rates," Journal of Monetary Economics, Vol. 40, pp. 239-278.

Frankel, J., and A. Rose, (1996), "Exchange Rate Crises in Emerging Markets.” Journal of International Economics, Vol. 41, 3-4, pp. 351-368. 
Goldberg, L. (2001). “When I U.S. Bank Lending to Emerging Markets Volatile?” National Bureau of Economic Research WP 8209, April.

Houston, J., C. James, and D. Marcus (1997). "Capital Market Frictions and the Role of Internal Capital Markets in Banking." Journal of Financial Economics, Vol. 46, pp. 135-164, November.

Jayaratne, J. and D. Morgan (2000), "Capital Market Frictions and Deposit Constraints at Banks," Journal of Money, Credit, and Banking, Vol. 32, 1, pp. 74-92.

Kaminsky, G., and C. Reinhart, (1999), "The Twin Crises: The Causes of Banking and Balanceof-Payments Problems." The American Economic Review, Vol. 89, 3, pp. 473-500.

Kashyap A., J. Stein, and D. Wilcox, (1993), "Monetary Policy and Credit Conditions: Evidence from the Composition of External Finance," American Economic Review, Vol. 83, pp. 78-98.

Kashyap A. and J. Stein (1994), "Monetary Policy and Bank Lending," in: Monetary Policy, Mankiw, G. (Ed.), NBER Studies in Business Cycles, Vol. 29, University of Chicago Press.

Kashyap A. and J. Stein (1995), "The Impact of Monetary Policy on Bank Balance Sheets," Carnegie-Rochester Conference Series in Public Policy, Vol. 42, pp. 151-195.

Kashyap, A. and J. Stein (2000).”What Do One Million Observations on Banks have to say about Monetary Policy?” American Economic Review, Vol. 90, 3, pp. 407-428.

Kishan, R. and T. Opiela (2000). "Bank Size, Bank Capital and the Bank Lending Channel." Journal of Money, Credit and Banking, Vol. 32, 1, pp. 121-141.

Peek, J. and E. Rosengren (1997). "The International Transmission of Financial Shocks: The Case of Japan.” American Economic Review, Vol. 87, 4, pp. 495-505.

Reinhart, C. and V. Reinhart (1999). "On the Use of Reserve Requirements in Dealing with Capital Flow Problems." International Journal of Finance and Economics, Vol. 4, 1, pp. 27-54.

Vázquez, F. (2001), "Bank Lending and Monetary Conditions in Developing Countries:

International Evidence on the Lending Channel." mimeo, University of Maryland, College Park. 
Figure 1. Money Market Rates and Reserve Requirements, Asian Countries, 1990-2000

- Money market rates (left scale) _ _ Req. reserves (right scale)
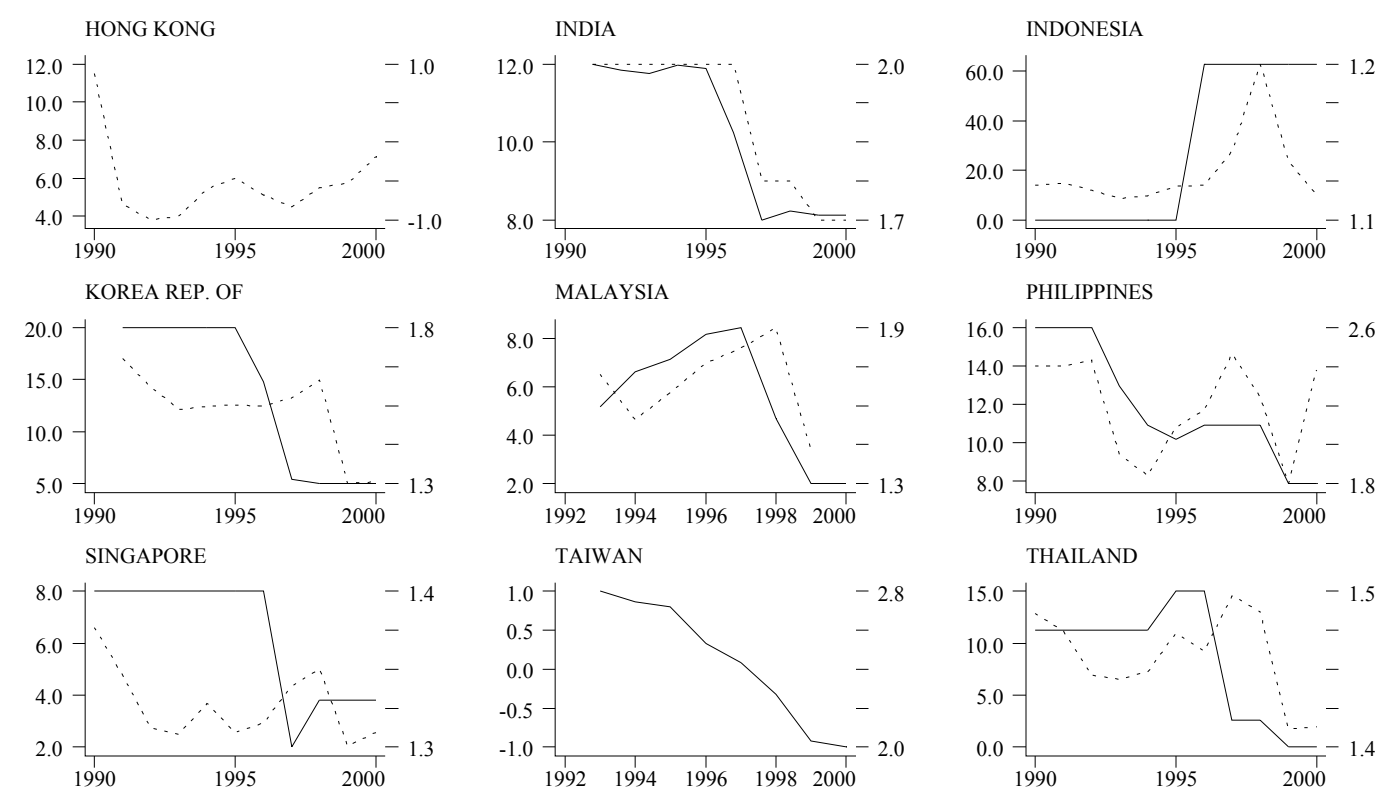

Source: Central Bank reports and International Financial Statistics.

For countries with incomplete or not available information on money market rates, an alternative indicator was used. The call money rate (series 60 ) was used for India, the 1-month average interbank offer rate for Hong Kong, and the interbank rate for Taiwan. 
Figure 2. Money Market Rates and Reserve Requirements, Latin America, 1990-2000 Money market rates (left scale) Req. reserves (right scale)
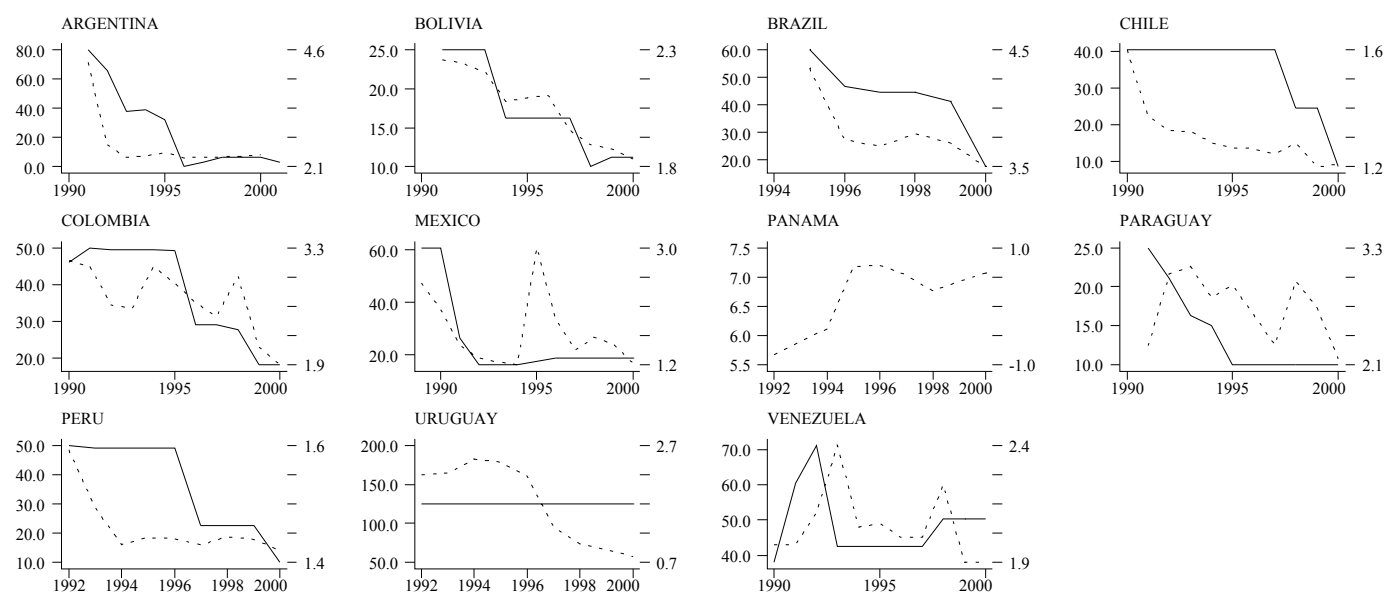

Source: Central Bank reports and International Financial Statistics.

For countries with incomplete or not available information on money market rates, an alternative indicator was used. Deposit rates (series 60L) were used for Bolivia, Chile, Colombia, Panamá, Paraguay, and Venezuela. 

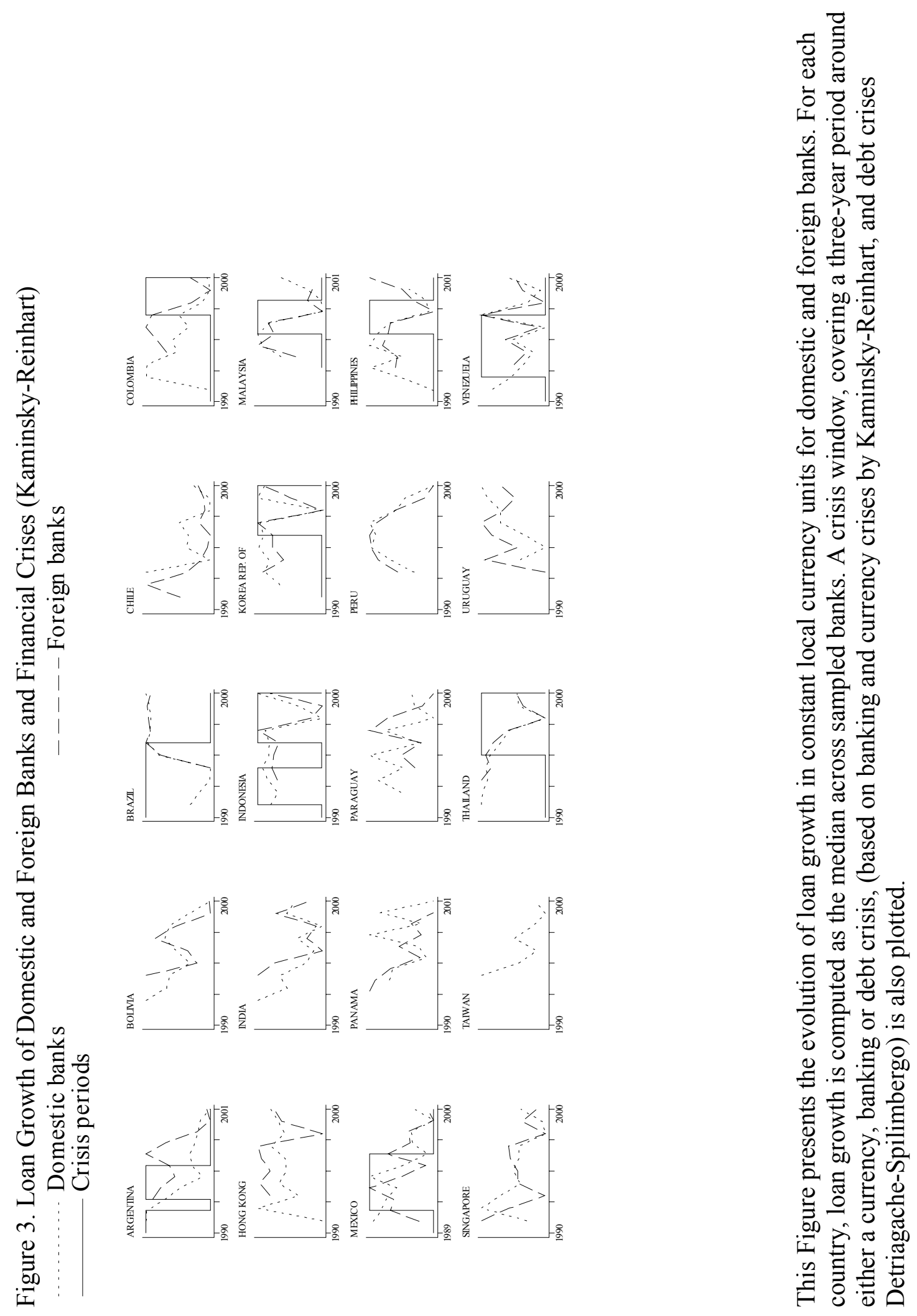

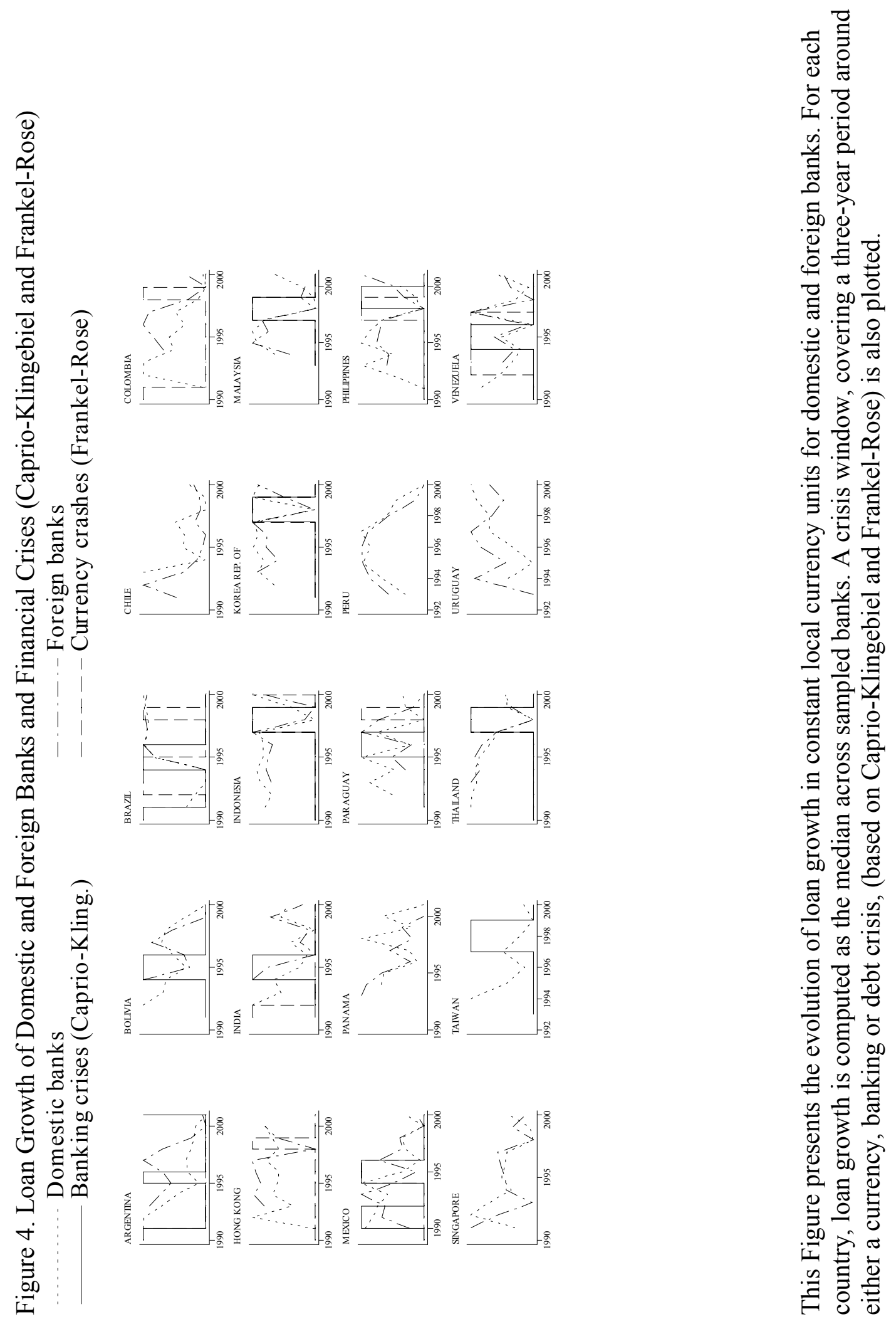
Table 1. Sample Coverage by Regions and Bank Ownership

\begin{tabular}{|c|c|c|c|c|c|c|c|c|c|}
\hline \multirow[b]{3}{*}{1989} & \multicolumn{3}{|c|}{ Asia } & \multicolumn{3}{|c|}{ Latin America } & \multicolumn{3}{|c|}{ Total Observations } \\
\hline & Domestic & Foreign & Total & Domestic & Foreign & Total & Freq. & Percent & Cum. \\
\hline & - & & $\overline{0}$ & 2 & 1 & $\overline{3}$ & 3 & 0.03 & 0.03 \\
\hline 1990 & 9 & 2 & 11 & 9 & 3 & 12 & 23 & 0.27 & 0.30 \\
\hline 1991 & 28 & 5 & 33 & 20 & 3 & 23 & 56 & 0.65 & 0.96 \\
\hline 1992 & 84 & 31 & 115 & 42 & 13 & 55 & 170 & 1.98 & 2.94 \\
\hline 1993 & 280 & 101 & 381 & 159 & 96 & 255 & 636 & 7.42 & 10.36 \\
\hline 1994 & 366 & 132 & 498 & 294 & 157 & 451 & 949 & 11.07 & 21.43 \\
\hline 1995 & 424 & 164 & 588 & 321 & 195 & 516 & 1104 & 12.88 & 34.30 \\
\hline 1996 & 452 & 182 & 634 & 346 & 212 & 558 & 1192 & 13.90 & 48.20 \\
\hline 1997 & 411 & 189 & 600 & 329 & 220 & 549 & 1149 & 13.40 & 61.60 \\
\hline 1998 & 399 & 190 & 589 & 336 & 241 & 577 & 1166 & 13.60 & 75.20 \\
\hline 1999 & 365 & 172 & 537 & 335 & 235 & 570 & 1107 & 12.91 & 88.12 \\
\hline 2000 & 281 & 142 & 423 & 319 & 250 & 569 & 992 & 11.57 & 99.69 \\
\hline 2001 & 5 & 1 & 6 & 14 & 7 & 21 & 27 & 0.31 & 100.00 \\
\hline Total & 3104 & 1311 & 4415 & 2526 & 1633 & 4159 & 8574 & 100 & \\
\hline
\end{tabular}

This Table shows the temporal distribution of the bank-level data. The sample comes from the BankScope database, and covers 20 emerging economies in Asia and Latin America. 
Table 2. Balance Sheet Structure by Regions and Quintiles of Bank Size

\begin{tabular}{|c|c|c|c|c|c|c|c|c|c|c|}
\hline \multirow[b]{2}{*}{ Quintiles of bank size } & \multicolumn{5}{|c|}{ Asian } & \multicolumn{5}{|c|}{ Latin America } \\
\hline & $0-20$ & $20-40$ & $40-60$ & $60-80$ & $80-100$ & $0-20$ & $20-40$ & $40-60$ & $60-80$ & $80-100$ \\
\hline Total loans & 50.8 & 51.5 & 52.2 & 57.8 & 60.4 & 51.5 & 54.7 & 53.2 & 47.9 & 50.0 \\
\hline Problem loans & 3.0 & 3.8 & 2.0 & 2.7 & 3.8 & 3.1 & 2.4 & 2.1 & 2.4 & 4.7 \\
\hline Loan loss reserves & 4.9 & 2.6 & 1.6 & 1.7 & 1.6 & 4.5 & 3.1 & 2.6 & 2.2 & 3.0 \\
\hline Net Loans & 45.9 & 49.1 & 50.7 & 56.4 & 59.2 & 48.1 & 52.9 & $\underline{51.7}$ & 47.1 & 49.8 \\
\hline Deposits with banks & $\overline{16.6}$ & $\overline{13.2}$ & $\overline{11.9}$ & $\overline{9.2}$ & $\overline{11.4}$ & $\overline{10.4}$ & $\overline{9.0}$ & $\overline{8.6}$ & $\overline{7.0}$ & 4.8 \\
\hline Securities & 14.8 & 12.4 & 14.5 & 13.8 & 10.4 & 15.9 & 15.2 & 18.0 & 21.6 & 18.7 \\
\hline Equity investment & 5.0 & 7.4 & 6.1 & 2.6 & 1.9 & 2.8 & 2.4 & 1.8 & 2.5 & 3.4 \\
\hline Total other earning assets & $\underline{44.2}$ & 43.0 & $\underline{41.5}$ & 34.8 & 30.7 & 33.1 & $\underline{31.4}$ & 33.6 & $\underline{36.9}$ & $\underline{34.6}$ \\
\hline Total non-earning assets & 7.2 & 6.2 & 5.8 & $\overline{6.6}$ & 7.9 & $\overline{13.9}$ & $\overline{12.2}$ & $\overline{11.5}$ & $\overline{13.3}$ & $\overline{12.9}$ \\
\hline Fixed assets & $\overline{2.7}$ & $\overline{1.7}$ & $\underline{2.0}$ & 2.2 & 2.2 & 4.9 & 3.5 & 3.2 & 2.7 & 2.6 \\
\hline Total assets & $1 \overline{00.0}$ & 100.0 & 100.0 & $\overline{100.0}$ & 100.0 & $\underline{100.0}$ & 100.0 & $\overline{100.0}$ & $\overline{100.0}$ & $\overline{100.0}$ \\
\hline Total deposits & 53.8 & 59.1 & 61.2 & 72.6 & 76.8 & 58.9 & 66.7 & 65.8 & 59.3 & 56.1 \\
\hline Money Market Funding & 9.6 & 8.2 & 8.4 & 4.7 & 3.6 & 8.0 & 9.3 & 12.0 & 14.8 & 16.4 \\
\hline Other Funding & 3.5 & 4.9 & 8.5 & 4.7 & 6.1 & 2.0 & 2.8 & 4.0 & 6.5 & 9.7 \\
\hline Other liabilities & 5.5 & 5.4 & 5.3 & 6.5 & 6.8 & 6.0 & 5.9 & 6.5 & 8.6 & 9.0 \\
\hline Total liabilities & 72.4 & 77.6 & 83.4 & 88.6 & 93.2 & 75.0 & 84.8 & 88.2 & 89.2 & 91.2 \\
\hline Equity & $\overline{27.6}$ & $\overline{22.5}$ & $\overline{16.6}$ & $\overline{11.4}$ & 6.7 & $\overline{25.0}$ & $\overline{15.2}$ & $\overline{11.8}$ & $\overline{10.8}$ & 8.8 \\
\hline Total liabilities and equity & 100.0 & 100.0 & 100.0 & 100.0 & 100.0 & $\underline{100.0}$ & 100.0 & 100.0 & 100.0 & 100.0 \\
\hline No. Observations & 578 & 761 & 888 & 972 & 1204 & 1131 & 948 & 821 & 737 & 504 \\
\hline Median Assets (million 1995 US\$) & 58 & 210 & 489 & 1,591 & 6,351 & 50 & 199 & 486 & 1,443 & 6,392 \\
\hline Mean Assets (million 1995 US\$) & 58 & 212 & 517 & 1,685 & 12,615 & 54 & 203 & 512 & 1,561 & 11,498 \\
\hline
\end{tabular}

Other earning assets include due from Central Banks, deposits with banks, bonds, securities, and equity investments. Total deposits include demand

deposits, saving deposits, certificates of deposits, and banks deposits. Equity includes equity reserves and share capital. 
Table 3. Summary Statistics by Regions and Bank Ownership

\begin{tabular}{|c|c|c|c|c|c|c|c|c|}
\hline & \multicolumn{4}{|c|}{ Domestic Banks } & \multicolumn{4}{|c|}{ Foreign Banks } \\
\hline & Mean & Median & Max. & Min. & Mean & Median & Max. & Min. \\
\hline \multicolumn{9}{|l|}{ A) Asia } \\
\hline Loan Growth & 11.2 & 10.5 & 240.4 & -128.6 & 5.1 & 8.3 & 218.2 & -206.9 \\
\hline Deposit Growth & 11.0 & 9.3 & 215.7 & -183.8 & 8.3 & 8.4 & 216.2 & -108.1 \\
\hline Net Loans/Total Deposits & 81.8 & 75.9 & 484.0 & 21.1 & 88.8 & 80.7 & 465.0 & 22.0 \\
\hline Net Loans/Total Assets & 56.1 & 57.4 & 87.1 & 11.8 & 54.5 & 58.0 & 87.0 & 10.0 \\
\hline Other Earning Assets/Total Assets & 31.4 & 28.5 & 78.4 & 5.2 & 32.7 & 30.0 & 75.9 & 6.1 \\
\hline Non Earning Assets/Total Assets & 9.9 & 8.0 & 74.4 & 5.0 & 11.2 & 8.3 & 71.2 & 5.0 \\
\hline Total Deposits/Total Assets & 75.2 & 79.5 & 94.9 & 5.2 & 68.9 & 74.8 & 94.9 & 7.2 \\
\hline Money Market Funding/Total Assets & 4.1 & 0.9 & 77.2 & 0.0 & 4.4 & 0.0 & 73.3 & 0.0 \\
\hline Total Liabilities/Total Assets & 90.1 & 92.3 & 99.7 & 40.9 & 86.1 & 89.9 & 99.8 & 40.3 \\
\hline Net Worth/Total Assets & 9.9 & 7.7 & 59.1 & 0.3 & 13.9 & 10.1 & 59.7 & 0.2 \\
\hline Efective Bank Spread & 3.8 & 3.8 & 19.0 & -14.9 & 5.1 & 3.7 & 135.3 & -4.4 \\
\hline \multicolumn{9}{|l|}{ B) Latin America } \\
\hline Loan Growth & 3.4 & 5.0 & 202.4 & -237.0 & 8.0 & 7.0 & 247.9 & -209.2 \\
\hline Deposit Growth & 3.6 & 5.3 & 229.8 & -236.6 & 5.4 & 5.8 & 196.2 & -181.8 \\
\hline Net Loans/Total Deposits & 89.0 & 80.4 & 494.1 & 20.1 & 89.1 & 81.2 & 478.3 & 20.6 \\
\hline Net Loans/Total Assets & 52.5 & 54.6 & 86.3 & 10.2 & 50.4 & 53.0 & 87.8 & 10.1 \\
\hline Other Earning Assets/Total Assets & 28.4 & 25.7 & 79.5 & 5.0 & 31.1 & 26.8 & 78.8 & 5.0 \\
\hline Non Earning Assets/Total Assets & 14.7 & 12.4 & 75.0 & 5.0 & 16.0 & 13.1 & 77.4 & 5.0 \\
\hline Total Deposits/Total Assets & 65.2 & 69.7 & 93.7 & 5.4 & 62.7 & 69.8 & 94.9 & 5.5 \\
\hline Money Market Funding/Total Assets & 9.0 & 2.2 & 64.3 & 0.0 & 12.5 & 3.3 & 74.1 & 0.0 \\
\hline Total Liabilities/Total Assets & 85.1 & 87.8 & 99.9 & 40.0 & 86.5 & 89.4 & 99.9 & 40.2 \\
\hline Net Worth/Total Assets & 14.9 & 12.2 & 60.0 & 0.1 & 13.5 & 10.6 & 59.8 & 0.1 \\
\hline Efective Bank Spread & 8.9 & 7.0 & 82.2 & -19.6 & 7.8 & 6.0 & 101.4 & -31.0 \\
\hline \multicolumn{9}{|l|}{ B) Whole Sample } \\
\hline Loan Growth & 6.9 & 8.0 & 240.4 & -237.0 & 7.2 & 7.5 & 247.9 & -209.2 \\
\hline Deposit Growth & 6.9 & 7.7 & 229.8 & -236.6 & 6.1 & 6.3 & 216.2 & -181.8 \\
\hline Net Loans/Total Deposits & 85.8 & 78.7 & 494.1 & 20.1 & 89.0 & 81.1 & 478.3 & 20.6 \\
\hline Net Loans/Total Assets & 54.1 & 55.6 & 87.1 & 10.2 & 51.5 & 54.4 & 87.8 & 10.0 \\
\hline Other Earning Assets/Total Assets & 29.7 & 26.7 & 79.5 & 5.0 & 31.5 & 27.7 & 78.8 & 5.0 \\
\hline Non Earning Assets/Total Assets & 12.6 & 9.7 & 75.0 & 5.0 & 14.8 & 11.5 & 77.4 & 5.0 \\
\hline Total Deposits/Total Assets & 69.6 & 74.6 & 94.9 & 5.2 & 64.3 & 71.0 & 94.9 & 5.5 \\
\hline Money Market Funding/Total Assets & 6.7 & 1.1 & 77.2 & 0.0 & 10.3 & 1.2 & 74.1 & 0.0 \\
\hline Total Liabilities/Total Assets & 87.3 & 89.6 & 99.9 & 40.0 & 86.4 & 89.5 & 99.9 & 40.2 \\
\hline Net Worth/Total Assets & 12.7 & 10.4 & 60.0 & 0.1 & 13.6 & 10.5 & 59.8 & 0.1 \\
\hline Efective Bank Spread & 6.6 & 4.7 & 82.2 & -19.6 & 7.1 & 5.2 & 135.3 & -31.0 \\
\hline
\end{tabular}


Table 4. GLS Estimates of Selected Variables on Monetary Conditions Latin-American subsample

\begin{tabular}{|c|c|c|c|c|c|c|}
\hline & $\begin{array}{c}{[1]} \\
\text { Loan Growth }\end{array}$ & $\begin{array}{c}{[2]} \\
\text { Deposit Growth }\end{array}$ & $\begin{array}{c}{[3]} \\
\text { Loans/Deposits }\end{array}$ & $\begin{array}{c}4] \\
\text { Bank Spread } \\
\end{array}$ & $\begin{array}{c}5] \\
\text { Deposit Rate }\end{array}$ & $\begin{array}{c}{[6]} \\
\text { Lending Rate }\end{array}$ \\
\hline \multicolumn{7}{|l|}{ Controls } \\
\hline GDP Growth & $\begin{array}{l}2.016 \\
{[0.369]^{* * *}}\end{array}$ & $\begin{array}{l}1.695 \\
{[0.391]^{* * *}}\end{array}$ & $\begin{array}{l}0.938 \\
{[1.838]}\end{array}$ & $\begin{array}{l}0.011 \\
{[0.047]}\end{array}$ & $\begin{array}{l}-0.129 \\
{[0.065]^{* *}}\end{array}$ & $\begin{array}{l}-0.107 \\
{[0.075]}\end{array}$ \\
\hline Foreign*GDP Growth & $\begin{array}{l}-0.329 \\
{[0.582]}\end{array}$ & $\begin{array}{l}-0.063 \\
{[0.614]}\end{array}$ & $\begin{array}{l}-2.619 \\
{[2.906]}\end{array}$ & $\begin{array}{l}-0.039 \\
{[0.072]}\end{array}$ & $\begin{array}{l}-0.111 \\
{[0.100]}\end{array}$ & $\begin{array}{l}-0.108 \\
{[0.115]}\end{array}$ \\
\hline Size & $\begin{array}{l}0.316 \\
{[0.032]^{* * *}}\end{array}$ & $\begin{array}{l}0.377 \\
{[0.032]^{* * *}}\end{array}$ & $\begin{array}{l}-0.242 \\
{[0.185]}\end{array}$ & $\begin{array}{l}-0.005 \\
{[0.004]}\end{array}$ & $\begin{array}{l}0.002 \\
{[0.005]}\end{array}$ & $\begin{array}{l}-0.008 \\
{[0.007]}\end{array}$ \\
\hline Foreign*Size & $\begin{array}{l}0.008 \\
{[0.040]}\end{array}$ & $\begin{array}{l}0.011 \\
{[0.040]}\end{array}$ & $\begin{array}{l}0.068 \\
{[0.239]}\end{array}$ & $\begin{array}{l}0.000 \\
{[0.006]}\end{array}$ & $\begin{array}{l}-0.007 \\
{[0.007]}\end{array}$ & $\begin{array}{l}-0.006 \\
{[0.009]}\end{array}$ \\
\hline Liquidity (t-1) & $\begin{array}{l}0.837 \\
{[0.127]^{* * *}}\end{array}$ & $\begin{array}{l}-0.043 \\
{[0.129]}\end{array}$ & $\begin{array}{l}-1.052 \\
{[0.686]}\end{array}$ & $\begin{array}{l}-0.036 \\
{[0.016]^{* *}}\end{array}$ & $\begin{array}{l}-0.048 \\
{[0.022]^{* *}}\end{array}$ & $\begin{array}{l}-0.068 \\
{[0.025]^{* * *}}\end{array}$ \\
\hline Foreign*Liquidity $(\mathrm{t}-1)$ & $\begin{array}{l}0.046 \\
{[0.188]}\end{array}$ & $\begin{array}{l}-0.210 \\
{[0.190]}\end{array}$ & $\begin{array}{l}1.796 \\
{[1.022]^{*}}\end{array}$ & $\begin{array}{l}0.005 \\
{[0.025]}\end{array}$ & $\begin{array}{l}-0.002 \\
{[0.032]}\end{array}$ & $\begin{array}{l}-0.010 \\
{[0.039]}\end{array}$ \\
\hline Capitalization (t-1) & $\begin{array}{l}1.109 \\
{[0.212]^{* * *}}\end{array}$ & $\begin{array}{l}2.178 \\
{[0.215]^{* * *}}\end{array}$ & $\begin{array}{l}-1.351 \\
{[1.058]}\end{array}$ & $\begin{array}{l}-0.065 \\
{[0.025]^{* *}}\end{array}$ & $\begin{array}{l}0.050 \\
{[0.035]}\end{array}$ & $\begin{array}{l}0.026 \\
{[0.040]}\end{array}$ \\
\hline Foreign*Capitalization (t-1) & $\begin{array}{l}0.704 \\
{[0.376]^{*}}\end{array}$ & $\begin{array}{l}1.337 \\
{[0.378]^{* * *}}\end{array}$ & $\begin{array}{l}0.386 \\
{[1.950]}\end{array}$ & $\begin{array}{l}0.039 \\
{[0.047]}\end{array}$ & $\begin{array}{l}-0.017 \\
{[0.063]}\end{array}$ & $\begin{array}{l}-0.015 \\
{[0.075]}\end{array}$ \\
\hline Monetary Conditions & & & & & & \\
\hline Reserve Requirements & $\begin{array}{l}-0.088 \\
{[0.043]^{* *}}\end{array}$ & $\begin{array}{l}-0.028 \\
{[0.047]}\end{array}$ & $\begin{array}{l}0.048 \\
{[0.204]}\end{array}$ & $\begin{array}{l}-0.001 \\
{[0.005]}\end{array}$ & $\begin{array}{l}-0.002 \\
{[0.007]}\end{array}$ & $\begin{array}{l}-0.004 \\
{[0.008]}\end{array}$ \\
\hline Foreign*Reserve Requirements & $\begin{array}{l}0.007 \\
{[0.082]}\end{array}$ & $\begin{array}{l}-0.046 \\
{[0.088]}\end{array}$ & $\begin{array}{l}0.227 \\
{[0.394]}\end{array}$ & $\begin{array}{l}-0.017 \\
{[0.010]^{*}}\end{array}$ & $\begin{array}{l}0.029 \\
{[0.014]^{* *}}\end{array}$ & $\begin{array}{l}0.014 \\
{[0.015]}\end{array}$ \\
\hline Money Market Rate & $\begin{array}{l}-0.042 \\
{[0.006]^{* * *}}\end{array}$ & $\begin{array}{l}-0.055 \\
{[0.007]^{* * *}}\end{array}$ & $\begin{array}{l}0.000 \\
{[0.029]}\end{array}$ & $\begin{array}{l}0.106 \\
{[0.028]^{* * *}}\end{array}$ & $\begin{array}{l}0.233 \\
{[0.039]^{* * *}}\end{array}$ & $\begin{array}{l}0.388 \\
{[0.045]^{* * *}}\end{array}$ \\
\hline Foreign*Money Market Rate & $\begin{array}{l}0.056 \\
{[0.034]^{*}}\end{array}$ & $\begin{array}{l}0.399 \\
{[0.102]^{* * *}}\end{array}$ & $\begin{array}{l}-0.013 \\
{[0.065]}\end{array}$ & $\begin{array}{l}0.070 \\
{[0.039]^{*}}\end{array}$ & $\begin{array}{l}0.026 \\
{[0.050]}\end{array}$ & $\begin{array}{l}0.107 \\
{[0.061]^{*}}\end{array}$ \\
\hline Observations & 2317 & 2350 & 2324 & 2194 & 2235 & 2197 \\
\hline Groups & 591 & 599 & 593 & 582 & 595 & 584 \\
\hline R. Sq. & 0.17 & 0.22 & 0.00 & 0.04 & 0.07 & 0.13 \\
\hline Rho AR(1) & 0.18 & 0.06 & 0.55 & 0.42 & 0.09 & 0.31 \\
\hline
\end{tabular}

This Table presents the results of GLS panel regressions with bank-level fixed effects, and allowing for panel-specific AR(1) errors. The sample comes from the Bankscope database and covers banks operating in selected Latin American countries from 1989-2001. Robust standard errors are reported between square brackets. Statistical significance at one, five, and ten percent level, are indicated by $* * *, * *, *$, respectively. Six models are considered, each one presented in a separate column. Each model uses a different dependent variable, specified in the first row of the Table. All models share the same set of explanatory variables, including country-level controls (GDP growth), bank-level controls (bank size, bank liquidity, and bank capitalization), and two indicators of monetary conditions (an index that tracks the evolution of reserve requirements, and the money market rate). The sample is split across domestic and foreign banks with the use of a dummy ("Foreign") which equals one for foreign banks and zero otherwise. 
Table 5. GLS Estimates of Selected Variables on Monetary Conditions Asian sub-sample

\begin{tabular}{|c|c|c|c|c|c|c|}
\hline & $\begin{array}{c}{[1]} \\
\text { Loan Growth } \\
\end{array}$ & $\begin{array}{c}2] \\
\text { Deposit Growth }\end{array}$ & $\begin{array}{c}{[3]} \\
\text { Loans/Deposits } \\
\end{array}$ & $\begin{array}{c}4] \\
\text { Bank Spread } \\
\end{array}$ & $\begin{array}{c}5] \\
\text { Deposit Rate }\end{array}$ & $\begin{array}{c}{[6]} \\
\text { Lending Rate } \\
\end{array}$ \\
\hline \multicolumn{7}{|l|}{ Controls } \\
\hline GDP Growth & $\begin{array}{l}1.906 \\
{[0.238]^{* * *}}\end{array}$ & $\begin{array}{l}1.364 \\
{[0.268]^{* * *}}\end{array}$ & $\begin{array}{l}-0.101 \\
{[1.260]}\end{array}$ & $\begin{array}{l}0.073 \\
{[0.026]^{* * *}}\end{array}$ & $\begin{array}{l}-0.099 \\
{[0.018]^{* * *}}\end{array}$ & $\begin{array}{l}-0.027 \\
{[0.031]}\end{array}$ \\
\hline Foreign*GDP Growth & $\begin{array}{l}0.389 \\
{[0.351]}\end{array}$ & $\begin{array}{l}1.202 \\
{[0.393]^{* * *}}\end{array}$ & $\begin{array}{l}-0.944 \\
{[1.887]}\end{array}$ & $\begin{array}{l}0.004 \\
{[0.040]}\end{array}$ & $\begin{array}{l}0.071 \\
{[0.028]^{* *}}\end{array}$ & $\begin{array}{l}0.063 \\
{[0.048]}\end{array}$ \\
\hline Size & $\begin{array}{l}0.281 \\
{[0.032]^{* * *}}\end{array}$ & $\begin{array}{l}0.315 \\
{[0.035]^{* * *}}\end{array}$ & $\begin{array}{l}0.126 \\
{[0.193]}\end{array}$ & $\begin{array}{l}0.001 \\
{[0.004]}\end{array}$ & $\begin{array}{l}-0.002 \\
{[0.002]}\end{array}$ & $\begin{array}{l}0.000 \\
{[0.005]}\end{array}$ \\
\hline Foreign*Size & $\begin{array}{l}0.127 \\
{[0.044]^{* * *}}\end{array}$ & $\begin{array}{l}0.209 \\
{[0.047]^{* * *}}\end{array}$ & $\begin{array}{l}0.303 \\
{[0.264]}\end{array}$ & $\begin{array}{l}0.009 \\
{[0.005]}\end{array}$ & $\begin{array}{l}-0.001 \\
{[0.003]}\end{array}$ & $\begin{array}{l}0.005 \\
{[0.006]}\end{array}$ \\
\hline Liquidity (t-1) & $\begin{array}{l}0.856 \\
{[0.107]^{* * *}}\end{array}$ & $\begin{array}{l}-0.224 \\
{[0.119]^{*}}\end{array}$ & $\begin{array}{l}-1.537 \\
{[0.646]^{* *}}\end{array}$ & $\begin{array}{l}-0.025 \\
{[0.013]^{*}}\end{array}$ & $\begin{array}{l}-0.036 \\
{[0.008]^{* * *}}\end{array}$ & $\begin{array}{l}-0.066 \\
{[0.015]^{* * *}}\end{array}$ \\
\hline Foreign*Liquidity (t-1) & $\begin{array}{l}0.309 \\
{[0.171]^{*}}\end{array}$ & $\begin{array}{l}0.595 \\
{[0.189]^{* * *}}\end{array}$ & $\begin{array}{l}0.602 \\
{[1.005]}\end{array}$ & $\begin{array}{l}-0.010 \\
{[0.021]}\end{array}$ & $\begin{array}{l}0.011 \\
{[0.013]}\end{array}$ & $\begin{array}{l}0.016 \\
{[0.025]}\end{array}$ \\
\hline Capitalization (t-1) & $\begin{array}{l}0.870 \\
{[0.138]^{* * *}}\end{array}$ & $\begin{array}{l}0.924 \\
{[0.156]^{* * *}}\end{array}$ & $\begin{array}{l}0.365 \\
{[0.806]}\end{array}$ & $\begin{array}{l}0.047 \\
{[0.015]^{* * *}}\end{array}$ & $\begin{array}{l}-0.013 \\
{[0.010]}\end{array}$ & $\begin{array}{l}0.033 \\
{[0.018]^{*}}\end{array}$ \\
\hline Foreign*Capitalization $(\mathrm{t}-1)$ & $\begin{array}{l}0.045 \\
{[0.216]}\end{array}$ & $\begin{array}{l}0.544 \\
{[0.238]^{* *}}\end{array}$ & $\begin{array}{l}-0.221 \\
{[1.257]}\end{array}$ & $\begin{array}{l}-0.032 \\
{[0.024]}\end{array}$ & $\begin{array}{l}0.046 \\
{[0.015]^{* * *}}\end{array}$ & $\begin{array}{l}-0.002 \\
{[0.029]}\end{array}$ \\
\hline Monetary Conditions & & & & & & \\
\hline Reserve Requirements & $\begin{array}{l}-0.033 \\
{[0.089]}\end{array}$ & $\begin{array}{l}0.111 \\
{[0.099]}\end{array}$ & $\begin{array}{l}-0.091 \\
{[0.473]}\end{array}$ & $\begin{array}{l}0.001 \\
{[0.009]}\end{array}$ & $\begin{array}{l}0.023 \\
{[0.006]^{* * *}}\end{array}$ & $\begin{array}{l}0.011 \\
{[0.011]}\end{array}$ \\
\hline Foreign*Reserve Requirements & $\begin{array}{l}-0.352 \\
{[0.196]^{*}}\end{array}$ & $\begin{array}{l}-0.329 \\
{[0.219]}\end{array}$ & $\begin{array}{l}-0.064 \\
{[1.039]}\end{array}$ & $\begin{array}{l}-0.011 \\
{[0.021]}\end{array}$ & $\begin{array}{l}-0.026 \\
{[0.014]^{*}}\end{array}$ & $\begin{array}{l}-0.025 \\
{[0.025]}\end{array}$ \\
\hline Money Market Rate & $\begin{array}{l}-0.793 \\
{[0.177]^{* * *}}\end{array}$ & $\begin{array}{l}-0.005 \\
{[0.195]}\end{array}$ & $\begin{array}{l}-1.245 \\
{[0.998]}\end{array}$ & $\begin{array}{l}-0.063 \\
{[0.019]^{* * *}}\end{array}$ & $\begin{array}{l}0.254 \\
{[0.013]^{* * *}}\end{array}$ & $\begin{array}{l}0.200 \\
{[0.023]^{* * *}}\end{array}$ \\
\hline Foreign*Money Market Rate & $\begin{array}{l}0.569 \\
{[0.260]^{* *}}\end{array}$ & $\begin{array}{l}-0.169 \\
{[0.288]}\end{array}$ & $\begin{array}{l}0.052 \\
{[1.435]}\end{array}$ & $\begin{array}{l}0.094 \\
{[0.029]^{* * *}}\end{array}$ & $\begin{array}{l}-0.158 \\
{[0.019]^{* * *}}\end{array}$ & $\begin{array}{l}-0.052 \\
{[0.034]}\end{array}$ \\
\hline Observations & 2631 & 2623 & 2582 & 2308 & 2380 & 2314 \\
\hline Groups & 627 & 628 & 613 & 571 & 593 & 573 \\
\hline R. Sq. & 0.26 & 0.17 & 0.01 & 0.04 & 0.40 & 0.15 \\
\hline Rho AR(1) & 0.15 & 0.02 & 0.45 & 0.40 & -0.01 & 0.42 \\
\hline
\end{tabular}

This Table presents the results of GLS panel regressions with bank-level fixed effects, and allowing for panel-specific AR(1) errors. The sample comes from the Bankscope database and covers banks operating in selected Latin American countries from 1989-2001. Robust standard errors are reported between square brackets. Statistical significance at one, five, and ten percent level, are indicated by ***, **, *, respectively. Six models are considered, each one presented in a separate column. Each model uses a different dependent variable, specified in the first row of the Table. All models share the same set of explanatory variables, including country-level controls (GDP growth), bank-level controls (bank size, bank liquidity, and bank capitalization), and two indicators of monetary conditions (an index that tracks the evolution of reserve requirements, and the money market rate). The sample is split across domestic and foreign banks with the use of a dummy ("Foreign") which equals one for foreign banks and zero otherwise. 
Table 6. GLS Regressions of Loan Growth on Monetary Conditions (I), Latin America

\begin{tabular}{|c|c|c|c|c|c|}
\hline & $\begin{array}{c}\text { Domestic } \\
\text { Banks }\end{array}$ & $\begin{array}{c}\text { Foreign } \\
\text { Banks }\end{array}$ & $\begin{array}{c}\mathrm{H} 0: \\
\text { Domestic= } \\
\text { Foreign }\end{array}$ & & \\
\hline \multicolumn{6}{|c|}{ Whole Sample } \\
\hline Money Market Rate & $\begin{array}{l}-0.042 * * * \\
(0.0064)\end{array}$ & $\begin{array}{r}0.013 \\
(0.0332)\end{array}$ & {$[0.10]$} & $\begin{array}{l}\text { Obs. } \\
\text { Groups }\end{array}$ & $\begin{array}{r}2317 \\
591\end{array}$ \\
\hline Reserve Requirements & $\begin{array}{l}-0.088 * * \\
(0.0431)\end{array}$ & $\begin{array}{r}-0.081 \\
(0.0697)\end{array}$ & {$[0.93]$} & $\begin{array}{l}\text { R-Squared } \\
\text { Rho AR(1) }\end{array}$ & $\begin{array}{l}0.167 \\
0.175\end{array}$ \\
\hline \multicolumn{6}{|c|}{ Capitalization Below 75 percentile } \\
\hline Money Market Rate & $\begin{array}{l}-0.042 \text { *** } \\
(0.0060)\end{array}$ & $\begin{array}{r}-0.019 \\
(0.0304)\end{array}$ & {$[0.46]$} & $\begin{array}{l}\text { Obs. } \\
\text { Groups }\end{array}$ & $\begin{array}{r}1759 \\
483\end{array}$ \\
\hline Reserve Requirements & $\begin{array}{c}-0.094 * \\
(0.0482)\end{array}$ & $\begin{array}{r}-0.057 \\
(0.0748)\end{array}$ & {$[0.68]$} & $\begin{array}{l}\text { R-Squared } \\
\text { Rho AR(1) }\end{array}$ & $\begin{array}{l}0.179 \\
0.207\end{array}$ \\
\hline
\end{tabular}

Capitalization Above 75 percentile

\begin{tabular}{|c|c|c|c|c|c|}
\hline \multirow[t]{2}{*}{ Money Market Rate } & 0.028 & 1.232 & {$[0.29]$} & Obs. & 401 \\
\hline & $(0.0336)$ & $(1.1285)$ & & Groups & 165 \\
\hline \multirow[t]{2}{*}{ Reserve Requirements } & 0.014 & 0.188 & {$[0.38]$} & R-Squared & 0.269 \\
\hline & $(0.0895)$ & $(0.1743)$ & & Rho AR(1) & 0.359 \\
\hline
\end{tabular}

Liquidity Below 75 percentile

Money Market Rate

Reserve Requirements

$\begin{array}{rr}-0.042 \text { *** } & -0.003 \\ (0.0053) & (0.0184) \\ -0.028 & -0.040 \\ (0.0392) & (0.0663)\end{array}$

Liquidity Above 75 percentile

\begin{tabular}{|c|c|c|c|c|c|}
\hline \multirow[t]{2}{*}{ Money Market Rate } & 0.984 & $\begin{array}{r}0.778 \\
2656)\end{array}$ & {$[0.91]$} & Obs. & 377 \\
\hline & $(1.2471)$ & $(1.2656)$ & & Groups & 171 \\
\hline Reserve Requirements & $\begin{array}{c}-0.603 \text { ** } \\
(0.3016)\end{array}$ & $\begin{array}{r}-0.206 \\
(0.2861)\end{array}$ & {$[0.34]$} & $\begin{array}{l}\text { R-Squared } \\
\text { Rho AR(1) }\end{array}$ & $\begin{array}{l}0.102 \\
0.195\end{array}$ \\
\hline
\end{tabular}

0.778

-0.206
$(0.2861)$
[0.04]

Obs.

1718

$[0.88]$

Groups

R-Squared

Rho AR(1)

501

0.272

0.259

This table presents selected coefficients from six sets of fixed-effects panel regressions. In all cases, the dependent variable is loan growth in constant local currency units. The reported coefficients are those associated with monetary conditions, measured by money market rates and an indicator of reserve requirements (which goes from 1 to 5 where a higher number indicates higher reserves). Controls, not reported here, include GDP growth and a set of bank characteristics (size, asset liquidity and capitalization). The table is divided in three panels. The upper displays the results of the regression based on the whole sample. The middle panel reports the results of two regressions, splitting the sample between banks with capitalization above (and below) the 75 percentile relative to other banks operating in the same country. The lower panel follows a similar structure, but the sample is split by liquidity levels. The estimation is based on GLS, allowing for panel-specific AR(1) processes.

Standard errors between parenthesis. * significant at $10 \%$; ** significant at $10 \%$; ** significant at $1 \%$. The p-values coresponding to the null of coefficient equality across domestic and foreign banks between [square] brackets. 
Table 7. GLS Regressions of Loan Growth on Monetary Conditions (I), Asia

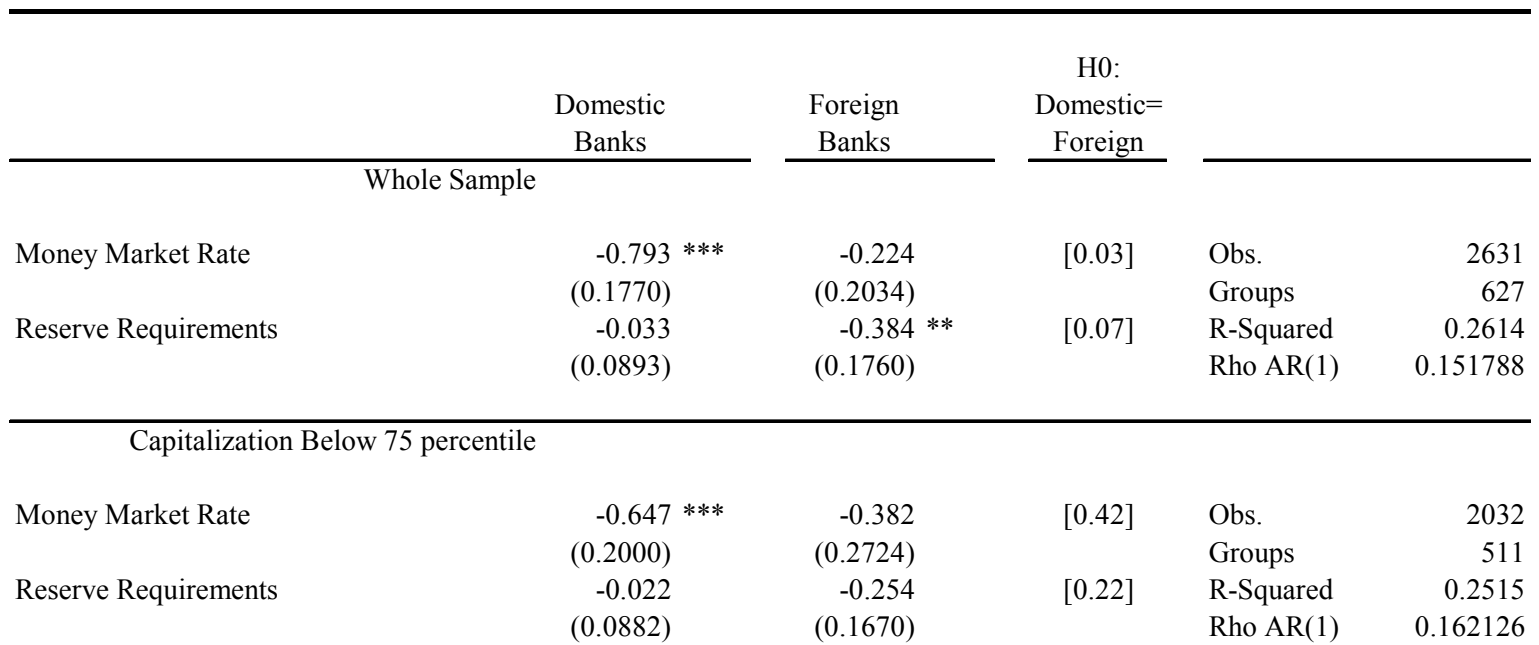

Capitalization Above 75 percentile

\begin{tabular}{|c|c|c|c|c|c|}
\hline \multirow[t]{2}{*}{ Money Market Rate } & -0.825 & -0.059 & [0.29] & Obs. & 442 \\
\hline & $(0.5376)$ & $(0.5424)$ & & Groups & 181 \\
\hline \multirow[t]{2}{*}{ Reserve Requirements } & 0.031 & -0.541 & {$[0.58]$} & R-Squared & 0.3708 \\
\hline & $(0.3771)$ & $(0.9635)$ & & Rho AR(1) & 0.206858 \\
\hline
\end{tabular}

Liquidity Below 75 percentile

\begin{tabular}{|c|c|c|c|c|c|}
\hline \multirow[t]{2}{*}{ Money Market Rate } & $-1.030 * * *$ & $-0.518 * * *$ & {$[0.02]$} & Obs. & 2105 \\
\hline & $(0.1560)$ & $(0.1778)$ & & Groups & 527 \\
\hline \multirow[t]{2}{*}{ Reserve Requirements } & -0.040 & $-0.447 * * *$ & {$[0.01]$} & R-Squared & 0.343 \\
\hline & $(0.0730)$ & $(0.1435)$ & & Rho AR(1) & 0.295 \\
\hline
\end{tabular}

Liquidity Above 75 percentile

\begin{tabular}{lrrrrr} 
Money Market Rate & -0.623 & 0.767 & {$[0.45]$} & Obs. & 358 \\
& $(1.4300)$ & $(1.1636)$ & & Groups & 161 \\
Reserve Requirements & -0.225 & -1.232 & {$[0.47]$} & R-Squared & 0.274 \\
& $(0.5974)$ & $(1.2425)$ & & Rho AR(1) & 0.242 \\
\hline
\end{tabular}

This table presents selected coefficients from six sets of fixed-effects panel regressions. In all cases, the dependent variable is loan growth in constant local currency units. The reported coefficients are those associated with monetary conditions, measured by money market rates and an indicator of reserve requirements (which goes from 1 to 5 where a higher number indicates higher reserves). Controls, not reported here, include GDP growth and a set of bank characteristics (size, asset liquidity and capitalization). The table is divided in three panels. The upper displays the results of the regression based on the whole sample. The middle panel reports the results of two regressions, splitting the sample between banks with capitalization above (and below) the 75 percentile relative to other banks operating in the same country. The lower panel follows a similar structure, but the sample is split by liquidity levels. The estimation is based on GLS, allowing for panel-specific AR(1) processes.

Standard errors between parenthesis. * significant at $10 \%$; ** significant at $10 \%$; *** significant at $1 \%$. The p-values coresponding to the null of coefficient equality across domestic and foreign banks between [square] brackets. 
Table 8. GLS Regressions of Loan Growth on Monetary Conditions (II), Latin America

\begin{tabular}{|c|c|c|c|c|c|}
\hline & $\begin{array}{c}\text { Domestic } \\
\text { Banks }\end{array}$ & $\begin{array}{c}\text { Foreign } \\
\text { Banks }\end{array}$ & $\begin{array}{c}\text { H0: } \\
\text { Domestic= } \\
\text { Foreign }\end{array}$ & & \multirow{4}{*}{$\begin{array}{r}2299 \\
589 \\
0.16 \\
0.19\end{array}$} \\
\hline \multicolumn{6}{|c|}{ Whole Sample } \\
\hline Exchange Rate Depreciation & $\begin{array}{l}-0.4138 \text { *** } \\
(0.0751)\end{array}$ & $\begin{array}{r}0.0482 \\
(0.1345)\end{array}$ & {$[0.00]$} & \multirow{3}{*}{$\begin{array}{l}\text { Obs. } \\
\text { Groups } \\
\text { R-Squared } \\
\text { Rho AR(1) }\end{array}$} & \\
\hline Reserve Requirements & $\begin{array}{c}-0.080 * \\
(0.0438)\end{array}$ & $\begin{array}{r}-0.081 \\
(0.0707)\end{array}$ & {$[0.98]$} & & \\
\hline US Federal Funds Rate & $\begin{array}{r}-0.035 \\
(0.0248)\end{array}$ & $\begin{array}{l}-0.049 * \\
(0.0263)\end{array}$ & {$[0.45]$} & & \\
\hline \multicolumn{6}{|c|}{ Capitalization Below 75 percentile } \\
\hline Exchange Rate Depreciation & $\begin{array}{l}-0.4398^{* * *} \\
(0.0750)\end{array}$ & $\begin{array}{r}0.0914 \\
(0.1314)\end{array}$ & {$[0.00]$} & $\begin{array}{l}\text { Obs. } \\
\text { Groups }\end{array}$ & $\begin{array}{r}1744 \\
483\end{array}$ \\
\hline Reserve Requirements & $\begin{array}{c}-0.094 * \\
(0.0488)\end{array}$ & $\begin{array}{r}-0.056 \\
(0.0762)\end{array}$ & {$[0.68]$} & $\begin{array}{l}\text { R-Squared } \\
\text { Rho AR(1) }\end{array}$ & $\begin{array}{l}0.17 \\
0.22\end{array}$ \\
\hline US Federal Funds Rate & $\begin{array}{c}-0.048 * \\
(0.0263)\end{array}$ & $\begin{array}{l}-0.057 * * \\
(0.0272)\end{array}$ & {$[0.68]$} & & \\
\hline \multicolumn{6}{|c|}{ Capitalization Above 75 percentile } \\
\hline Exchange Rate Depreciation & $\begin{array}{c}-0.0729 \\
(0.2306)\end{array}$ & $\begin{array}{r}0.0362 \\
(0.1450)\end{array}$ & {$[0.78]$} & $\begin{array}{l}\text { Obs. } \\
\text { Groups }\end{array}$ & $\begin{array}{l}398 \\
162\end{array}$ \\
\hline Reserve Requirements & $\begin{array}{r}0.022 \\
(0.0922)\end{array}$ & $\begin{array}{r}-0.039 \\
(0.0676)\end{array}$ & {$[0.32]$} & $\begin{array}{l}\text { R-Squared } \\
\text { Rho AR(1) }\end{array}$ & $\begin{array}{l}0.27 \\
0.39\end{array}$ \\
\hline US Federal Funds Rate & $\begin{array}{r}-0.011 \\
(0.0663)\end{array}$ & $\begin{array}{r}-0.004 \\
(0.0250)\end{array}$ & {$[0.28]$} & & \\
\hline \multicolumn{6}{|c|}{ Liquidity Below 75 percentile } \\
\hline Exchange Rate Depreciation & $\begin{array}{l}-0.4186^{* * *} \\
(0.0727)\end{array}$ & $\begin{array}{r}0.0966 \\
(0.5544)\end{array}$ & {$[0.00]$} & $\begin{array}{l}\text { Obs. } \\
\text { Grouns }\end{array}$ & $\begin{array}{r}1707 \\
497\end{array}$ \\
\hline Reserve Requirements & $\begin{array}{r}-0.029 \\
(0.0404)\end{array}$ & $\begin{array}{r}0.217 \\
(0.1743)\end{array}$ & {$[0.90]$} & $\begin{array}{l}\text { R-Squared } \\
\text { Rho AR(1) }\end{array}$ & $\begin{array}{l}0.26 \\
0.25\end{array}$ \\
\hline US Federal Funds Rate & $\begin{array}{r}0.005 \\
(0.0221)\end{array}$ & $\begin{array}{r}0.060 \\
(0.0671)\end{array}$ & {$[0.60]$} & & \\
\hline \multicolumn{6}{|c|}{ Liquidity Above 75 percentile } \\
\hline Exchange Rate Depreciation & $\begin{array}{r}-0.1468 \\
(0.3556)\end{array}$ & $\begin{array}{r}0.0966 \\
(0.5544)\end{array}$ & {$[0.90]$} & $\begin{array}{l}\text { Obs. } \\
\text { Groups }\end{array}$ & $\begin{array}{l}373 \\
169\end{array}$ \\
\hline Reserve Requirements & $\begin{array}{r}-0.425 \\
(0.2939)\end{array}$ & $\begin{array}{r}0.217 \\
(0.1743)\end{array}$ & {$[0.78]$} & $\begin{array}{l}\text { R-Squared } \\
\text { Rho AR(1) }\end{array}$ & $\begin{array}{l}0.13 \\
0.20\end{array}$ \\
\hline US Federal Funds Rate & $\begin{array}{r}-0.012 \\
(0.1363)\end{array}$ & $\begin{array}{r}0.060 \\
(0.0671)\end{array}$ & {$[0.08]$} & & \\
\hline
\end{tabular}

This table presents selected coefficients from six sets of fixed-effects panel regressions. In all cases, the dependent variable is loan growth in constant local currency units. The reported coefficients are those associated with monetary conditions, measured by the Federal Funds rate, the yearly variation of the exchange rate (increase=depreciation) and an indicator of reserve

requirements (which goes from 1 to 5 where a higher number indicates higher reserves). Controls, not reported here, include GDP growth and a set of bank characteristics (size, asset liquidity and capitalization). The table is divided in three panels. The upper displays the results of the regression based on the whole sample. The middle panel reports the results of two regressions, splitting the sample between banks with capitalization above (and below) the 75 percentile relative to other banks operating in the same country. The lower panel follows a similar structure, but the sample is split by liquidity levels. The estimation is based on GLS, allowing for panel-specific AR(1) processes.

Standard errors between parenthesis. * significant at $10 \% ; * *$ significant at $10 \%$; *** significant at $1 \%$. The p-values coresponding to the null of coefficient equality across domestic and foreign banks between [square] brackets. 
Table 9. GLS Regressions of Loan Growth on Monetary Conditions (II), Asia

\begin{tabular}{|c|c|c|c|c|c|}
\hline & $\begin{array}{c}\text { Domestic } \\
\text { Banks }\end{array}$ & $\begin{array}{c}\text { Foreign } \\
\text { Banks }\end{array}$ & $\begin{array}{c}\text { H0: } \\
\text { Domestic= } \\
\text { Foreign } \\
\end{array}$ & & \\
\hline \multicolumn{6}{|c|}{ Whole Sample } \\
\hline Exchange Rate Depreciation & $\begin{array}{l}-0.1188 * \\
(0.0691)\end{array}$ & $\begin{array}{l}0.2317^{* * * *} \\
(0.0722)\end{array}$ & {$[0.00]$} & $\begin{array}{l}\text { Obs. } \\
\text { Groups }\end{array}$ & $\begin{array}{r}2631 \\
627\end{array}$ \\
\hline Reserve Requirements & $\begin{array}{r}-0.075 \\
(0.0922)\end{array}$ & $\begin{array}{l}-0.4611^{* * *} \\
(0.1759)\end{array}$ & {$[0.05]$} & $\begin{array}{l}\text { R-Squared } \\
\text { Rho AR(1) }\end{array}$ & $\begin{array}{l}0.26 \\
0.14\end{array}$ \\
\hline US Federal Funds Rate & $\begin{array}{l}0.039 \text { ** } \\
(0.0165)\end{array}$ & $\begin{array}{r}-0.013 \\
(0.0197)\end{array}$ & {$[0.00]$} & & \\
\hline \multicolumn{6}{|c|}{ Capitalization Below 75 percentile } \\
\hline Exchange Rate Depreciation & $\begin{array}{l}-0.2040 \text { ** } \\
(0.0802)\end{array}$ & $\begin{array}{l}0.2345 \text { *** } \\
(0.0905)\end{array}$ & {$[0.00]$} & $\begin{array}{l}\text { Obs. } \\
\text { Groups }\end{array}$ & $\begin{array}{r}2032 \\
511\end{array}$ \\
\hline Reserve Requirements & $\begin{array}{r}-0.032 \\
(0.0915)\end{array}$ & $\begin{array}{c}-0.328^{* *} \\
(0.1658)\end{array}$ & {$[0.12]$} & $\begin{array}{l}\text { R-Squared } \\
\text { Rho AR(1) }\end{array}$ & $\begin{array}{l}0.26 \\
0.15\end{array}$ \\
\hline US Federal Funds Rate & $\begin{array}{c}0.054^{* * *} \\
(0.0171)\end{array}$ & $\begin{array}{r}-0.018 \\
(0.0202)\end{array}$ & {$[0.00]$} & & \\
\hline
\end{tabular}

Capitalization Above 75 percentile

$\begin{array}{lrcclr}\text { Exchange Rate Depreciation } & 0.3491 * & 0.0683 & {[0.62]} & \text { Obs. } & 442 \\ & (0.1861) & (0.0623) & & \text { Groups } & 181 \\ \text { Reserve Requirements } & -0.253 & -0.515 * * * & {[0.81]} & \text { R-Squared } & 0.38 \\ & (0.3863) & (0.1440) & & \text { Rho AR(1) } & 0.21 \\ \text { US Federal Funds Rate } & -0.052 & -0.028 * & {[0.59]} & & \end{array}$

Liquidity Below 75 percentile

\begin{tabular}{|c|c|c|c|c|c|}
\hline \multirow[t]{2}{*}{ Exchange Rate Depreciation } & $-0.3327 * * *$ & 0.2154 & {$[0.00]$} & Obs. & 2105 \\
\hline & $(0.0647)$ & $(0.1917)$ & & Groups & 527 \\
\hline \multirow[t]{2}{*}{ Reserve Requirements } & -0.025 & -0.496 & {$[0.00]$} & R-Squared & 0.34 \\
\hline & $(0.0770)$ & $(0.9463)$ & & Rho AR(1) & 0.28 \\
\hline \multirow[t]{2}{*}{ US Federal Funds Rate } & $0.040 * * *$ & -0.019 & {$[0.00]$} & & \\
\hline & $(0.0134)$ & $(0.0627)$ & & & \\
\hline \multicolumn{6}{|c|}{ Liquidity Above 75 percentile } \\
\hline \multirow[t]{2}{*}{ Exchange Rate Depreciation } & -0.0347 & 0.2154 & {$[0.36]$} & Obs. & 358 \\
\hline & $(0.3986)$ & $(0.1917)$ & & Groups & 161 \\
\hline \multirow[t]{2}{*}{ Reserve Requirements } & -0.238 & -0.496 & {$[0.51]$} & R-Squared & 0.29 \\
\hline & $(0.6127)$ & $(0.9463)$ & & Rho AR(1) & 0.25 \\
\hline \multirow[t]{2}{*}{ US Federal Funds Rate } & -0.061 & -0.019 & {$[0.18]$} & & \\
\hline & $(0.0899)$ & $(0.0627)$ & & & \\
\hline
\end{tabular}

This table presents selected coefficients from six sets of fixed-effects panel regressions. In all cases, the dependent variable is loan growth in constant local currency units. The reported coefficients are those associated with monetary conditions, measured by the Federal Funds rate, the yearly variation of the exchange rate (increase=depreciation) and an indicator of reserve requirements (which goes from 1 to 5 where a higher number indicates higher reserves). Controls, not reported here, include GDP growth and a set of bank characteristics (size, asset liquidity and capitalization). The table is divided in three panels. The upper displays the results of the regression based on the whole sample. The middle panel reports the results of two regressions, splitting the sample between banks with capitalization above (and below) the 75 percentile relative to other banks operating in the same country. The lower panel follows a similar structure, but the sample is split by liquidity levels. The estimation is based on GLS, allowing for panel-specific AR(1) processes.

Standard errors between parenthesis. * significant at $10 \% ; * *$ significant at $10 \% ; * * *$ significant at $1 \%$. The p-values coresponding to the null of coefficient equality across domestic and foreign banks between [square] brackets. 
Table 10. Latin America, Regressions Using a Crises Window

\begin{tabular}{|c|c|c|c|c|c|c|}
\hline & $\begin{array}{c}\text { [1] } \\
\text { Loan Growth }\end{array}$ & $\begin{array}{l}\text { [2] } \\
\text { Deposit } \\
\text { Growth }\end{array}$ & $\begin{array}{c}{[3]} \\
\text { Loans to } \\
\text { Deposits }\end{array}$ & $\begin{array}{c}\text { [4] } \\
\text { Bank Spread }\end{array}$ & Deposit Rate & Lending Rate \\
\hline \multicolumn{7}{|l|}{ Bank-level controls } \\
\hline Size & $\begin{array}{c}0.2270 \\
{[0.039]^{* * *}}\end{array}$ & $\begin{array}{c}0.2710 \\
{[0.038]^{* * *}}\end{array}$ & $\begin{array}{c}-0.3110 \\
{[0.190]}\end{array}$ & $\begin{array}{c}-0.0130 \\
{[0.004]^{* * *}}\end{array}$ & $\begin{array}{c}0.0120 \\
{[0.005]^{* *}}\end{array}$ & $\begin{array}{c}0.0010 \\
{[0.007]}\end{array}$ \\
\hline Foreign*Size & $\begin{array}{c}0.0220 \\
{[0.053]}\end{array}$ & $\begin{array}{c}0.0570 \\
{[0.052]}\end{array}$ & $\begin{array}{l}0.1010 \\
{[0.154]}\end{array}$ & $\begin{array}{l}0.0000 \\
{[0.006]}\end{array}$ & $\begin{array}{c}-0.0100 \\
{[0.006]^{*}}\end{array}$ & $\begin{array}{l}-0.0130 \\
{[0.009]}\end{array}$ \\
\hline Liquidity (t-1) & $\begin{array}{c}0.6740 \\
{[0.155]^{* * *}}\end{array}$ & $\begin{array}{l}-0.0860 \\
{[0.139]}\end{array}$ & $\begin{array}{c}-1.6310 \\
{[0.778]^{* *}}\end{array}$ & $\begin{array}{c}-0.0550 \\
{[0.019]^{* * *}}\end{array}$ & $\begin{array}{c}-0.0770 \\
{[0.036]^{* *}}\end{array}$ & $\begin{array}{c}-0.0830 \\
{[0.029]^{* * *}}\end{array}$ \\
\hline Foreign*Liquidity (t-1) & $\begin{array}{c}0.4110 \\
{[0.223]^{*}}\end{array}$ & $\begin{array}{c}0.1140 \\
{[0.217]}\end{array}$ & $\begin{array}{c}1.5120 \\
{[0.836]^{*}}\end{array}$ & $\begin{array}{c}0.1090 \\
{[0.036]^{* * *}}\end{array}$ & $\begin{array}{c}0.0400 \\
{[0.042]}\end{array}$ & $\begin{array}{c}0.1050 \\
{[0.050]^{* *}}\end{array}$ \\
\hline Capitalization (t-1) & $\begin{array}{c}1.2380 \\
{[0.325]^{* * *}}\end{array}$ & $\begin{array}{c}2.2150 \\
{[0.320]^{* * *}}\end{array}$ & $\begin{array}{l}-1.9040 \\
{[1.677]}\end{array}$ & $\begin{array}{l}-0.0030 \\
{[0.035]}\end{array}$ & $\begin{array}{c}0.0800 \\
{[0.048]^{*}}\end{array}$ & $\begin{array}{c}0.1170 \\
{[0.060]^{*}}\end{array}$ \\
\hline Foreign*Capitalization (t-1) & $\begin{array}{c}0.8360 \\
{[0.527]}\end{array}$ & $\begin{array}{c}0.7930 \\
{[0.520]}\end{array}$ & $\begin{array}{l}2.3640 \\
{[1.791]}\end{array}$ & $\begin{array}{l}0.0550 \\
{[0.065]}\end{array}$ & $\begin{array}{l}-0.0410 \\
{[0.056]}\end{array}$ & $\begin{array}{l}-0.0240 \\
{[0.089]}\end{array}$ \\
\hline \multicolumn{7}{|l|}{ Target variables } \\
\hline Dummy Crises & $\begin{array}{c}-0.0980 \\
{[0.038]^{* * *}}\end{array}$ & $\begin{array}{c}-0.1380 \\
{[0.038]^{* * *}}\end{array}$ & $\begin{array}{c}-0.2770 \\
{[0.209]}\end{array}$ & $\begin{array}{c}0.0300 \\
{[0.005]^{* * *}}\end{array}$ & $\begin{array}{c}0.0370 \\
{[0.011]^{* * *}}\end{array}$ & $\begin{array}{c}0.0580 \\
{[0.008]^{* * *}}\end{array}$ \\
\hline Foreign*Dummy Crises & $\begin{array}{c}0.1340 \\
{[0.070]^{*}}\end{array}$ & $\begin{array}{c}0.0710 \\
{[0.081]}\end{array}$ & $\begin{array}{c}0.0700 \\
{[0.259]}\end{array}$ & $\begin{array}{l}-0.0040 \\
{[0.011]}\end{array}$ & $\begin{array}{c}-0.0290 \\
{[0.014]^{* *}}\end{array}$ & $\begin{array}{c}-0.0270 \\
{[0.015]^{*}}\end{array}$ \\
\hline Constant & $\begin{array}{c}0.0220 \\
{[0.014]}\end{array}$ & $\begin{array}{c}0.0260 \\
{[0.012]^{* *}}\end{array}$ & $\begin{array}{c}1.1860 \\
{[0.055]^{* * *}}\end{array}$ & $\begin{array}{c}0.0710 \\
{[0.002]^{* * *}}\end{array}$ & $\begin{array}{c}0.1210 \\
{[0.003]^{* * *}}\end{array}$ & $\begin{array}{c}0.1930 \\
{[0.002]^{* * *}}\end{array}$ \\
\hline $\begin{array}{l}\text { Observations } \\
\text { R-squared }\end{array}$ & $\begin{array}{l}3019 \\
0.41\end{array}$ & $\begin{array}{c}3055 \\
0.37\end{array}$ & $\begin{array}{c}3020 \\
0.55\end{array}$ & $\begin{array}{c}2898 \\
0.86\end{array}$ & $\begin{array}{c}2955 \\
0.60\end{array}$ & $\begin{array}{c}2906 \\
0.71\end{array}$ \\
\hline
\end{tabular}

This Table compares the response of selected bank-level variables to GDP growth and crises/non-crises period across domestic and foreign banks. The regressions were computed with bank-level fixed effects and robust standard errors. The sample covers the Latin American countries.

* significant at $10 \% ; * *$ significant at $5 \%$; ** significant at $1 \%$ 
Table 11. Asia, Regressions Using a Crises Window

\begin{tabular}{|c|c|c|c|c|c|c|}
\hline & $\begin{array}{c}1] \\
\text { Loan Growth }\end{array}$ & $\begin{array}{c}{[2]} \\
\text { Deposit } \\
\text { Growth }\end{array}$ & $\begin{array}{c}3] \\
\text { Loans to } \\
\text { Deposits }\end{array}$ & Bank Spread & Deposit Rate & $\begin{array}{c}6] \\
\text { Lending Rate }\end{array}$ \\
\hline \multicolumn{7}{|l|}{ Bank-level controls } \\
\hline Size & $\begin{array}{c}0.1270 \\
{[0.035]^{* * * *}}\end{array}$ & $\begin{array}{c}0.2060 \\
{[0.035]^{* * *}}\end{array}$ & $\begin{array}{l}0.0780 \\
{[0.118]}\end{array}$ & $\begin{array}{c}-0.0080 \\
{[0.003]^{* * *}}\end{array}$ & $\begin{array}{l}0.0030 \\
{[0.002]}\end{array}$ & $\begin{array}{l}-0.0050 \\
{[0.003]}\end{array}$ \\
\hline Foreign*Size & $\begin{array}{c}0.1120 \\
{[0.051]^{* *}}\end{array}$ & $\begin{array}{c}0.2010 \\
{[0.052]^{* * *}}\end{array}$ & $\begin{array}{c}0.4140 \\
{[0.303]}\end{array}$ & $\begin{array}{c}0.0080 \\
{[0.005]}\end{array}$ & $\begin{array}{l}-0.0020 \\
{[0.003]}\end{array}$ & $\begin{array}{c}0.0050 \\
{[0.007]}\end{array}$ \\
\hline Liquidity (t-1) & $\begin{array}{c}0.7570 \\
{[0.145]^{* * *}}\end{array}$ & $\begin{array}{r}-0.0910 \\
{[0.092]}\end{array}$ & $\begin{array}{c}-1.7290 \\
{[0.609]^{* * *}}\end{array}$ & $\begin{array}{l}-0.0220 \\
{[0.011]^{*}}\end{array}$ & $\begin{array}{c}-0.0510 \\
{[0.010]^{* * *}}\end{array}$ & $\begin{array}{c}-0.0790 \\
{[0.013]^{* * *}}\end{array}$ \\
\hline Foreign*Liquidity (t-1) & $\begin{array}{l}0.2920 \\
{[0.233]}\end{array}$ & $\begin{array}{c}0.4940 \\
{[0.208]^{* *}}\end{array}$ & $\begin{array}{l}-0.6090 \\
{[1.856]}\end{array}$ & $\begin{array}{c}0.0100 \\
{[0.059]}\end{array}$ & $\begin{array}{l}0.0230 \\
{[0.019]}\end{array}$ & $\begin{array}{c}0.0360 \\
{[0.073]}\end{array}$ \\
\hline Capitalization (t-1) & $\begin{array}{c}0.8860 \\
{[0.206]^{* * *}}\end{array}$ & $\begin{array}{c}1.2560 \\
{[0.211]^{* * *}}\end{array}$ & $\begin{array}{l}0.3880 \\
{[0.643]}\end{array}$ & $\begin{array}{l}0.0270 \\
{[0.031]}\end{array}$ & $\begin{array}{l}0.0140 \\
{[0.011]}\end{array}$ & $\begin{array}{c}0.0430 \\
{[0.030]}\end{array}$ \\
\hline Foreign*Capitalization $(\mathrm{t}-1)$ & $\begin{array}{l}0.1720 \\
{[0.402]}\end{array}$ & $\begin{array}{c}0.2740 \\
{[0.449]}\end{array}$ & $\begin{array}{c}0.2290 \\
{[0.831]}\end{array}$ & $\begin{array}{c}0.0210 \\
{[0.039]}\end{array}$ & $\begin{array}{l}0.0220 \\
{[0.021]}\end{array}$ & $\begin{array}{c}0.0420 \\
{[0.043]}\end{array}$ \\
\hline \multicolumn{7}{|l|}{ Target variables } \\
\hline Dummy Crises & $\begin{array}{c}-0.0920 \\
{[0.019]^{* * *}}\end{array}$ & $\begin{array}{c}-0.0440 \\
{[0.019]^{* *}}\end{array}$ & $\begin{array}{l}0.0090 \\
{[0.049]}\end{array}$ & $\begin{array}{c}-0.0040 \\
{[0.001]^{* *}}\end{array}$ & $\begin{array}{c}0.0230 \\
{[0.002]^{* * *}}\end{array}$ & $\begin{array}{c}0.0190 \\
{[0.002]^{* * *}}\end{array}$ \\
\hline Foreign*Dummy Crises & $\begin{array}{l}-0.0300 \\
{[0.040]}\end{array}$ & $\begin{array}{c}-0.1100 \\
{[0.039]^{* * *}}\end{array}$ & $\begin{array}{c}-0.3190 \\
{[0.154]^{* *}}\end{array}$ & $\begin{array}{c}0.0020 \\
{[0.005]}\end{array}$ & $\begin{array}{c}-0.0050 \\
{[0.003]^{*}}\end{array}$ & $\begin{array}{l}-0.0030 \\
{[0.006]}\end{array}$ \\
\hline Constant & $\begin{array}{c}0.1250 \\
{[0.008]^{* * *}}\end{array}$ & $\begin{array}{c}0.1260 \\
{[0.010]^{* * *}}\end{array}$ & $\begin{array}{c}1.2440 \\
{[0.040]^{* * *}}\end{array}$ & $\begin{array}{c}0.0490 \\
{[0.001]^{* * *}}\end{array}$ & $\begin{array}{c}0.0680 \\
{[0.001]^{* * *}}\end{array}$ & $\begin{array}{c}0.1150 \\
{[0.001]^{* * *}}\end{array}$ \\
\hline $\begin{array}{l}\text { Observations } \\
\text { R-squared }\end{array}$ & $\begin{array}{c}3343 \\
0.43\end{array}$ & $\begin{array}{r}3327 \\
0.37\end{array}$ & $\begin{array}{c}3271 \\
0.71\end{array}$ & $\begin{array}{c}2956 \\
0.92\end{array}$ & $\begin{array}{c}3050 \\
0.94\end{array}$ & $\begin{array}{c}2965 \\
0.90\end{array}$ \\
\hline
\end{tabular}

This Table compares the response of selected bank-level variables to GDP growth and crises/non-crises period across domestic and foreign banks. The regressions were computed with bank-level fixed effects and robust standard errors. The sample covers the Asian countries.

Robust standard errors in brackets

* significant at $10 \% ; * *$ significant at $5 \% ; * * *$ significant at $1 \%$ 
Table 12. Latin America, Regressions Specifying Pre- and Post- Crises Years

\begin{tabular}{|c|c|c|c|c|c|c|}
\hline & $\begin{array}{c}1] \\
\text { Loan Growth }\end{array}$ & $\begin{array}{c}{[2]} \\
\text { Deposit } \\
\text { Growth } \\
\end{array}$ & $\begin{array}{c}3] \\
\text { Loans to } \\
\text { Deposits } \\
\end{array}$ & $\begin{array}{c}4] \\
\text { Bank Spread } \\
\end{array}$ & Deposit Rate & Lending Rate \\
\hline Bank & & & & & & \\
\hline Size & $\begin{array}{c}0.2330 \\
{[0.040]^{* * *}}\end{array}$ & $\begin{array}{c}0.2790 \\
{[0.039]^{* * *}}\end{array}$ & $\begin{array}{c}-0.3100 \\
{[0.187]^{*}}\end{array}$ & $\begin{array}{c}-0.0130 \\
{[0.004]^{* * *}}\end{array}$ & $\begin{array}{c}0.0100 \\
{[0.005]^{* *}}\end{array}$ & $\begin{array}{l}0.0000 \\
{[0.007]}\end{array}$ \\
\hline Foreign*Size & $\begin{array}{l}0.0190 \\
{[0.054]}\end{array}$ & $\begin{array}{c}0.0560 \\
{[0.053]}\end{array}$ & $\begin{array}{l}0.1010 \\
{[0.152]}\end{array}$ & $\begin{array}{c}0.0000 \\
{[0.006]}\end{array}$ & $\begin{array}{l}-0.0090 \\
{[0.006]}\end{array}$ & $\begin{array}{l}-0.0130 \\
{[0.009]}\end{array}$ \\
\hline Liquidity (t-1) & $\begin{array}{c}0.6790 \\
{[0.154]^{* * *}}\end{array}$ & $\begin{array}{l}-0.0790 \\
{[0.138]}\end{array}$ & $\begin{array}{c}-1.6320 \\
{[0.781]^{* *}}\end{array}$ & $\begin{array}{c}-0.0550 \\
{[0.019]^{* * *}}\end{array}$ & $\begin{array}{c}-0.0780 \\
{[0.036]^{* *}}\end{array}$ & $\begin{array}{c}-0.0840 \\
{[0.029]^{* * *}}\end{array}$ \\
\hline Foreign*Liquidity (t-1) & $\begin{array}{c}0.4030 \\
{[0.223]^{*}}\end{array}$ & $\begin{array}{l}0.0910 \\
{[0.217]}\end{array}$ & $\begin{array}{c}1.5070 \\
{[0.839]^{*}}\end{array}$ & $\begin{array}{c}0.1110 \\
{[0.036]^{* * *}}\end{array}$ & $\begin{array}{l}0.0410 \\
{[0.042]}\end{array}$ & $\begin{array}{c}0.1080 \\
{[0.050]^{* *}}\end{array}$ \\
\hline Capitalization (t-1) & $\begin{array}{c}1.2350 \\
{[0.326]^{* * * *}}\end{array}$ & $\begin{array}{c}2.2250 \\
{[0.322]^{* * *}}\end{array}$ & $\begin{array}{l}-1.9140 \\
{[1.670]}\end{array}$ & $\begin{array}{l}-0.0010 \\
{[0.035]}\end{array}$ & $\begin{array}{c}0.0750 \\
{[0.047]}\end{array}$ & $\begin{array}{c}0.1150 \\
{[0.059]^{*}}\end{array}$ \\
\hline Foreign*Capitalization $(\mathrm{t}-1)$ & $\begin{array}{l}0.8360 \\
{[0.529]}\end{array}$ & $\begin{array}{l}0.7750 \\
{[0.523]}\end{array}$ & $\begin{array}{l}2.3690 \\
{[1.784]}\end{array}$ & $\begin{array}{c}0.0530 \\
{[0.066]}\end{array}$ & $\begin{array}{l}-0.0350 \\
{[0.055]}\end{array}$ & $\begin{array}{l}-0.0220 \\
{[0.089]}\end{array}$ \\
\hline & & & & & & \\
\hline Crises (T-1) & $\begin{array}{c}0.0690 \\
{[0.066]}\end{array}$ & $\begin{array}{l}0.0620 \\
{[0.070]}\end{array}$ & $\begin{array}{l}-0.1570 \\
{[0.110]}\end{array}$ & $\begin{array}{c}0.0240 \\
{[0.007]^{* * *}}\end{array}$ & $\begin{array}{l}-0.0060 \\
{[0.006]}\end{array}$ & $\begin{array}{c}0.0180 \\
{[0.010]^{*}}\end{array}$ \\
\hline Foreign*Crises $(\mathrm{T}-1)$ & $\begin{array}{l}0.0850 \\
{[0.105]}\end{array}$ & $\begin{array}{c}0.1840 \\
{[0.108]^{*}}\end{array}$ & $\begin{array}{l}0.1480 \\
{[0.133]}\end{array}$ & $\begin{array}{l}-0.0080 \\
{[0.014]}\end{array}$ & $\begin{array}{l}-0.0100 \\
{[0.011]}\end{array}$ & $\begin{array}{l}-0.0180 \\
{[0.018]}\end{array}$ \\
\hline Crises (T) & $\begin{array}{c}-0.0730 \\
{[0.069]}\end{array}$ & $\begin{array}{c}-0.0730 \\
{[0.076]}\end{array}$ & $\begin{array}{c}-0.2820 \\
{[0.138]^{* *}}\end{array}$ & $\begin{array}{c}0.0310 \\
{[0.007]^{* * *}}\end{array}$ & $\begin{array}{c}0.0150 \\
{[0.007]^{* *}}\end{array}$ & $\begin{array}{c}0.0450 \\
{[0.010]^{* * *}}\end{array}$ \\
\hline Foreign*Crises $(\mathrm{T})$ & $\begin{array}{l}0.1120 \\
{[0.134]}\end{array}$ & $\begin{array}{c}0.0780 \\
{[0.150]}\end{array}$ & $\begin{array}{l}0.0990 \\
{[0.141]}\end{array}$ & $\begin{array}{l}-0.0220 \\
{[0.015]}\end{array}$ & $\begin{array}{l}-0.0050 \\
{[0.014]}\end{array}$ & $\begin{array}{l}-0.0270 \\
{[0.019]}\end{array}$ \\
\hline Crises $(\mathrm{T}+1)$ & $\begin{array}{c}-0.1370 \\
{[0.040]^{* * *}}\end{array}$ & $\begin{array}{c}-0.2030 \\
{[0.039]^{* * *}}\end{array}$ & $\begin{array}{c}-0.3030 \\
{[0.281]}\end{array}$ & $\begin{array}{c}0.0290 \\
{[0.007]^{* * *}}\end{array}$ & $\begin{array}{c}0.0560 \\
{[0.016]^{* * *}}\end{array}$ & $\begin{array}{c}0.0720 \\
{[0.011]^{* * *}}\end{array}$ \\
\hline Foreign*Crises $(\mathrm{T}+1)$ & $\begin{array}{c}0.1690 \\
{[0.070]^{* *}}\end{array}$ & $\begin{array}{c}0.0680 \\
{[0.085]}\end{array}$ & $\begin{array}{l}0.0570 \\
{[0.371]}\end{array}$ & $\begin{array}{c}0.0070 \\
{[0.014]}\end{array}$ & $\begin{array}{c}-0.0480 \\
{[0.019]^{* *}}\end{array}$ & $\begin{array}{l}-0.0320 \\
{[0.021]}\end{array}$ \\
\hline Constant & $\begin{array}{l}0.0190 \\
{[0.014]}\end{array}$ & $\begin{array}{c}0.0220 \\
{[0.012]^{*}}\end{array}$ & $\begin{array}{c}1.1850 \\
{[0.054]^{* * *}}\end{array}$ & $\begin{array}{c}0.0710 \\
{[0.002]^{* * *}}\end{array}$ & $\begin{array}{c}0.1220 \\
{[0.003]^{* * *}}\end{array}$ & $\begin{array}{c}0.1940 \\
{[0.002]^{* * *}}\end{array}$ \\
\hline $\begin{array}{l}\text { Observations } \\
\text { R-squared }\end{array}$ & $\begin{array}{l}3019 \\
0.41\end{array}$ & $\begin{array}{r}3055 \\
0.38\end{array}$ & $\begin{array}{c}3020 \\
0.55\end{array}$ & $\begin{array}{c}2898 \\
0.86\end{array}$ & $\begin{array}{c}2955 \\
0.60\end{array}$ & $\begin{array}{c}2906 \\
0.71\end{array}$ \\
\hline
\end{tabular}

Robust standard errors in brackets

* significant at $10 \%$; ** significant at $5 \%$; *** significant at $1 \%$

This Table compares the response of selected bank-level variables to GDP growth and crises/non-crises period across domestic and foreign banks. The regressions were computed with bank-level fixed effects and robust standard errors. The sample covers the Latin American countries. 
Table 13. Asia, Regressions Specifying Pre- and Post- Crises Years

\begin{tabular}{|c|c|c|c|c|c|c|}
\hline & $\begin{array}{c}1] \\
\text { Loan Growth }\end{array}$ & $\begin{array}{c}{[2]} \\
\text { Deposit } \\
\text { Growth } \\
\end{array}$ & $\begin{array}{c}3] \\
\text { Loans to } \\
\text { Deposits } \\
\end{array}$ & $\begin{array}{c}4] \\
\text { Bank Spread } \\
\end{array}$ & Deposit Rate & Lending Rate \\
\hline \multicolumn{7}{|c|}{ Bank-level controls } \\
\hline Size & $\begin{array}{c}0.1240 \\
{[0.035]^{* * *}}\end{array}$ & $\begin{array}{c}0.2030 \\
{[0.035]^{* * *}}\end{array}$ & $\begin{array}{l}0.0830 \\
{[0.118]}\end{array}$ & $\begin{array}{c}-0.0090 \\
{[0.003]^{* * *}}\end{array}$ & $\begin{array}{l}0.0030 \\
{[0.002]}\end{array}$ & $\begin{array}{l}-0.0050 \\
{[0.003]}\end{array}$ \\
\hline Foreign*Size & $\begin{array}{c}0.1030 \\
{[0.050]^{* *}}\end{array}$ & $\begin{array}{c}0.1940 \\
{[0.052]^{* * *}}\end{array}$ & $\begin{array}{c}0.4040 \\
{[0.305]}\end{array}$ & $\begin{array}{c}0.0080 \\
{[0.005]}\end{array}$ & $\begin{array}{l}-0.0040 \\
{[0.003]}\end{array}$ & $\begin{array}{c}0.0040 \\
{[0.007]}\end{array}$ \\
\hline Liquidity (t-1) & $\begin{array}{c}0.8030 \\
{[0.146]^{* * *}}\end{array}$ & $\begin{array}{l}-0.0650 \\
{[0.092]}\end{array}$ & $\begin{array}{c}-1.7330 \\
{[0.612]^{* * *}}\end{array}$ & $\begin{array}{c}-0.0200 \\
{[0.011]^{*}}\end{array}$ & $\begin{array}{c}-0.0500 \\
{[0.011]^{* * *}}\end{array}$ & $\begin{array}{c}-0.0770 \\
{[0.013]^{* * *}}\end{array}$ \\
\hline Foreign*Liquidity (t-1) & $\begin{array}{c}0.3410 \\
{[0.231]}\end{array}$ & $\begin{array}{c}0.5500 \\
{[0.207]^{* * *}}\end{array}$ & $\begin{array}{l}-0.5260 \\
{[1.838]}\end{array}$ & $\begin{array}{c}0.0090 \\
{[0.059]}\end{array}$ & $\begin{array}{c}0.0210 \\
{[0.019]}\end{array}$ & $\begin{array}{c}0.0330 \\
{[0.072]}\end{array}$ \\
\hline Capitalization (t-1) & $\begin{array}{c}0.8020 \\
{[0.204]^{* * *}}\end{array}$ & $\begin{array}{c}1.2090 \\
{[0.214]^{* * *}}\end{array}$ & $\begin{array}{l}0.3610 \\
{[0.648]}\end{array}$ & $\begin{array}{l}0.0260 \\
{[0.031]}\end{array}$ & $\begin{array}{l}0.0080 \\
{[0.012]}\end{array}$ & $\begin{array}{l}0.0390 \\
{[0.031]}\end{array}$ \\
\hline Foreign*Capitalization $(\mathrm{t}-1)$ & $\begin{array}{l}0.1330 \\
{[0.391]}\end{array}$ & $\begin{array}{l}0.2240 \\
{[0.446]}\end{array}$ & $\begin{array}{l}0.2730 \\
{[0.837]}\end{array}$ & $\begin{array}{l}0.0190 \\
{[0.039]}\end{array}$ & $\begin{array}{l}0.0230 \\
{[0.020]}\end{array}$ & $\begin{array}{l}0.0380 \\
{[0.044]}\end{array}$ \\
\hline \multicolumn{7}{|c|}{ Target variables } \\
\hline Crises (T-1) & $\begin{array}{c}0.0380 \\
{[0.011]^{* * *}}\end{array}$ & $\begin{array}{l}0.0160 \\
{[0.014]}\end{array}$ & $\begin{array}{l}0.0470 \\
{[0.034]}\end{array}$ & $\begin{array}{c}0.0020 \\
{[0.001]^{* *}}\end{array}$ & $\begin{array}{l}0.0010 \\
{[0.002]}\end{array}$ & $\begin{array}{c}0.0040 \\
{[0.001]^{* * *}}\end{array}$ \\
\hline Foreign*Crises $(\mathrm{T}-1)$ & $\begin{array}{l}0.0170 \\
{[0.024]}\end{array}$ & $\begin{array}{l}-0.0160 \\
{[0.029]}\end{array}$ & $\begin{array}{c}-0.1570 \\
{[0.086]^{*}}\end{array}$ & $\begin{array}{l}0.0000 \\
{[0.003]}\end{array}$ & $\begin{array}{c}0.0060 \\
{[0.002]^{* *}}\end{array}$ & $\begin{array}{l}0.0040 \\
{[0.004]}\end{array}$ \\
\hline Crises $(\mathrm{T})$ & $\begin{array}{c}-0.0330 \\
{[0.013]^{* *}}\end{array}$ & $\begin{array}{l}-0.0100 \\
{[0.015]}\end{array}$ & $\begin{array}{l}-0.0170 \\
{[0.034]}\end{array}$ & $\begin{array}{l}-0.0010 \\
{[0.001]}\end{array}$ & $\begin{array}{c}0.0180 \\
{[0.002]^{* * *}}\end{array}$ & $\begin{array}{c}0.0150 \\
{[0.001]^{* * *}}\end{array}$ \\
\hline Foreign $*$ Crises $(\mathrm{T})$ & $\begin{array}{l}0.0450 \\
{[0.032]}\end{array}$ & $\begin{array}{l}-0.0170 \\
{[0.032]}\end{array}$ & $\begin{array}{c}-0.1730 \\
{[0.103]^{*}}\end{array}$ & $\begin{array}{l}0.0010 \\
{[0.004]}\end{array}$ & $\begin{array}{l}-0.0030 \\
{[0.003]}\end{array}$ & $\begin{array}{l}0.0000 \\
{[0.005]}\end{array}$ \\
\hline Crises $(\mathrm{T}+1)$ & $\begin{array}{c}-0.1360 \\
{[0.016]^{* * *}}\end{array}$ & $\begin{array}{c}-0.0640 \\
{[0.019]^{* * *}}\end{array}$ & $\begin{array}{l}-0.0310 \\
{[0.032]}\end{array}$ & $\begin{array}{l}-0.0020 \\
{[0.001]}\end{array}$ & $\begin{array}{c}0.0110 \\
{[0.002]^{* * *}}\end{array}$ & $\begin{array}{c}0.0090 \\
{[0.002]^{* * *}}\end{array}$ \\
\hline Foreign*Crises $(\mathrm{T}+1)$ & $\begin{array}{c}-0.0540 \\
{[0.030]^{*}}\end{array}$ & $\begin{array}{c}-0.1270 \\
{[0.031]^{* * *}}\end{array}$ & $\begin{array}{l}-0.1100 \\
{[0.074]}\end{array}$ & $\begin{array}{l}-0.0020 \\
{[0.003]}\end{array}$ & $\begin{array}{l}-0.0030 \\
{[0.002]}\end{array}$ & $\begin{array}{l}-0.0060 \\
{[0.004]}\end{array}$ \\
\hline Constant & $\begin{array}{c}0.1140 \\
{[0.008]^{* * *}}\end{array}$ & $\begin{array}{c}0.1180 \\
{[0.009]^{* * *}}\end{array}$ & $\begin{array}{c}1.2390 \\
{[0.040]^{* * *}}\end{array}$ & $\begin{array}{c}0.0480 \\
{[0.001]^{* * *}}\end{array}$ & $\begin{array}{c}0.0700 \\
{[0.001]^{* * *}}\end{array}$ & $\begin{array}{c}0.1160 \\
{[0.001]^{* * *}}\end{array}$ \\
\hline $\begin{array}{l}\text { Observations } \\
\text { R-squared }\end{array}$ & $\begin{array}{c}3343 \\
0.45\end{array}$ & $\begin{array}{c}3327 \\
0.38\end{array}$ & $\begin{array}{c}3271 \\
0.71\end{array}$ & $\begin{array}{c}2956 \\
0.92\end{array}$ & $\begin{array}{r}3050 \\
0.94\end{array}$ & $\begin{array}{r}2965 \\
0.90\end{array}$ \\
\hline
\end{tabular}

Robust standard errors in brackets

* significant at $10 \% ; * *$ significant at $5 \% ; * * *$ significant at $1 \%$

This Table compares the response of selected bank-level variables to GDP growth and crises/non-crises period across domestic and foreign banks. The regressions were computed with bank-level fixed effects and robust standard errors. The sample covers the Asian countries. 
Table 14. Latin America, Alternative Crises Definitions

\begin{tabular}{|c|c|c|c|c|c|c|}
\hline & $\begin{array}{c}1] \\
\text { Loan Growth }\end{array}$ & $\begin{array}{l}{[2]} \\
\text { Deposit } \\
\text { Growth } \\
\end{array}$ & $\begin{array}{c}{[3]} \\
\text { Loans to } \\
\text { Deposits } \\
\end{array}$ & $\begin{array}{c}{[4]} \\
\text { Bank Spread }\end{array}$ & Deposit Rate & $\begin{array}{c}6] \\
\text { Lending Rate }\end{array}$ \\
\hline \multicolumn{7}{|c|}{ Caprio-Kinglebiel } \\
\hline Crises C-K (T-1) & $\begin{array}{c}0.006 \\
{[0.047]}\end{array}$ & $\begin{array}{c}-0.075 \\
{[0.045]^{*}}\end{array}$ & $\begin{array}{c}-0.267 \\
{[0.127]^{* *}}\end{array}$ & $\begin{array}{c}0.025 \\
{[0.006]^{* * *}}\end{array}$ & $\begin{array}{c}0.000 \\
{[0.006]}\end{array}$ & $\begin{array}{c}0.026 \\
{[0.009]^{* * *}}\end{array}$ \\
\hline Foreign*Crises C-K (T-1) & $\begin{array}{c}-0.142 \\
{[0.082]^{*}}\end{array}$ & $\begin{array}{c}0.005 \\
{[0.079]}\end{array}$ & $\begin{array}{c}0.032 \\
{[0.135]}\end{array}$ & $\begin{array}{c}-0.024 \\
{[0.010]^{* *}}\end{array}$ & $\begin{array}{l}-0.008 \\
{[0.010]}\end{array}$ & $\begin{array}{c}-0.033 \\
{[0.012]^{* * *}}\end{array}$ \\
\hline Crises C-K (T) & $\begin{array}{c}-0.101 \\
{[0.046]^{* *}}\end{array}$ & $\begin{array}{c}-0.171 \\
{[0.047]^{* * *}}\end{array}$ & $\begin{array}{c}-0.350 \\
{[0.282]}\end{array}$ & $\begin{array}{c}0.045 \\
{[0.007]^{* * *}}\end{array}$ & $\begin{array}{c}0.045 \\
{[0.012]^{* * *}}\end{array}$ & $\begin{array}{c}0.081 \\
{[0.011]^{* * *}}\end{array}$ \\
\hline Foreign*Crises C-K (T) & $\begin{array}{c}0.136 \\
{[0.075]^{*}}\end{array}$ & $\begin{array}{c}0.123 \\
{[0.087]}\end{array}$ & $\begin{array}{c}0.019 \\
{[0.326]}\end{array}$ & $\begin{array}{c}0.000 \\
{[0.011]}\end{array}$ & $\begin{array}{c}-0.057 \\
{[0.015]^{* * *}}\end{array}$ & $\begin{array}{c}-0.051 \\
{[0.017]^{* * *}}\end{array}$ \\
\hline Crises C-K $(\mathrm{T}+1)$ & $\begin{array}{c}0.066 \\
{[0.039]^{*}}\end{array}$ & $\begin{array}{c}-0.005 \\
{[0.041]}\end{array}$ & $\begin{array}{c}-0.316 \\
{[0.275]}\end{array}$ & $\begin{array}{c}0.009 \\
{[0.005]^{*}}\end{array}$ & $\begin{array}{c}-0.008 \\
{[0.014]}\end{array}$ & $\begin{array}{c}0.013 \\
{[0.009]}\end{array}$ \\
\hline Foreign*Crises C-K $(\mathrm{T}+1)$ & $\begin{array}{c}0.123 \\
{[0.077]}\end{array}$ & $\begin{array}{c}0.042 \\
{[0.087]}\end{array}$ & $\begin{array}{c}-0.108 \\
{[0.410]}\end{array}$ & $\begin{array}{c}0.023 \\
{[0.012]^{*}}\end{array}$ & $\begin{array}{c}-0.014 \\
{[0.016]}\end{array}$ & $\begin{array}{c}-0.003 \\
{[0.017]}\end{array}$ \\
\hline \multicolumn{7}{|c|}{ Frankel-Rose } \\
\hline Crises F-R (T-1) & $\begin{array}{c}-0.029 \\
{[0.042]}\end{array}$ & $\begin{array}{c}0.157 \\
{[0.051]^{* * *}}\end{array}$ & $\begin{array}{c}0.141 \\
{[0.195]}\end{array}$ & $\begin{array}{c}0.002 \\
{[0.006]}\end{array}$ & $\begin{array}{c}-0.012 \\
{[0.009]}\end{array}$ & $\begin{array}{c}-0.006 \\
{[0.011]}\end{array}$ \\
\hline Foreign*Crises F-R (T-1) & $\begin{array}{c}0.034 \\
{[0.101]}\end{array}$ & $\begin{array}{c}0.006 \\
{[0.107]}\end{array}$ & $\begin{array}{c}0.254 \\
{[0.465]}\end{array}$ & $\begin{array}{l}-0.006 \\
{[0.010]}\end{array}$ & $\begin{array}{l}-0.005 \\
{[0.013]}\end{array}$ & $\begin{array}{l}-0.012 \\
{[0.015]}\end{array}$ \\
\hline Crises F-R (T) & $\begin{array}{c}-0.226 \\
{[0.055]^{* * *}}\end{array}$ & $\begin{array}{c}-0.026 \\
{[0.060]}\end{array}$ & $\begin{array}{c}-0.205 \\
{[0.140]}\end{array}$ & $\begin{array}{c}0.011 \\
{[0.006]^{*}}\end{array}$ & $\begin{array}{c}0.036 \\
{[0.009]^{* * *}}\end{array}$ & $\begin{array}{c}0.046 \\
{[0.011]^{* * *}}\end{array}$ \\
\hline Foreign*Crises F-R (T) & $\begin{array}{c}0.184 \\
{[0.100]^{*}}\end{array}$ & $\begin{array}{c}0.073 \\
{[0.111]}\end{array}$ & $\begin{array}{c}0.738 \\
{[0.561]}\end{array}$ & $\begin{array}{c}0.009 \\
{[0.012]}\end{array}$ & $\begin{array}{l}-0.007 \\
{[0.015]}\end{array}$ & $\begin{array}{c}0.003 \\
{[0.020]}\end{array}$ \\
\hline Crises F-R $(\mathrm{T}+1)$ & $\begin{array}{c}-0.150 \\
{[0.043]^{* * *}}\end{array}$ & $\begin{array}{c}-0.110 \\
{[0.042]^{* * *}}\end{array}$ & $\begin{array}{c}0.126 \\
{[0.292]}\end{array}$ & $\begin{array}{c}0.009 \\
{[0.007]}\end{array}$ & $\begin{array}{c}0.043 \\
{[0.011]^{* * *}}\end{array}$ & $\begin{array}{c}0.056 \\
{[0.013]^{* * *}}\end{array}$ \\
\hline Foreign*Crises F-R $(\mathrm{T}+1)$ & $\begin{array}{c}0.123 \\
{[0.079]}\end{array}$ & $\begin{array}{c}0.091 \\
{[0.083]}\end{array}$ & $\begin{array}{c}-0.028 \\
{[0.436]}\end{array}$ & $\begin{array}{c}0.005 \\
{[0.015]}\end{array}$ & $\begin{array}{c}0.035 \\
{[0.020]^{*}}\end{array}$ & $\begin{array}{c}0.038 \\
{[0.022]^{*}}\end{array}$ \\
\hline \multicolumn{7}{|c|}{ Kaminsky-Reinhart } \\
\hline Crises K-R (T-1) & $\begin{array}{c}0.016 \\
{[0.057]}\end{array}$ & $\begin{array}{c}0.010 \\
{[0.061]}\end{array}$ & $\begin{array}{c}-0.149 \\
{[0.103]}\end{array}$ & $\begin{array}{c}0.024 \\
{[0.006]^{* * *}}\end{array}$ & $\begin{array}{c}0.004 \\
{[0.005]}\end{array}$ & $\begin{array}{c}0.027 \\
{[0.008]^{* * *}}\end{array}$ \\
\hline Foreign*Crises K-R (T-1) & $\begin{array}{c}-0.033 \\
{[0.089]}\end{array}$ & $\begin{array}{c}0.091 \\
{[0.084]}\end{array}$ & $\begin{array}{c}0.046 \\
{[0.121]}\end{array}$ & $\begin{array}{c}-0.017 \\
{[0.012]}\end{array}$ & $\begin{array}{l}-0.009 \\
{[0.007]}\end{array}$ & $\begin{array}{c}-0.025 \\
{[0.013]^{*}}\end{array}$ \\
\hline Crises K-R (T) & $\begin{array}{c}-0.069 \\
{[0.069]}\end{array}$ & $\begin{array}{c}-0.069 \\
{[0.076]}\end{array}$ & $\begin{array}{c}-0.287 \\
{[0.141]^{* *}}\end{array}$ & $\begin{array}{c}0.034 \\
{[0.007]^{* * *}}\end{array}$ & $\begin{array}{c}0.025 \\
{[0.006]^{* * *}}\end{array}$ & $\begin{array}{c}0.059 \\
{[0.010]^{* * *}}\end{array}$ \\
\hline Foreign*Crises K-R (T) & $\begin{array}{c}0.116 \\
{[0.133]}\end{array}$ & $\begin{array}{c}0.088 \\
{[0.149]}\end{array}$ & $\begin{array}{c}0.101 \\
{[0.142]}\end{array}$ & $\begin{array}{l}-0.023 \\
{[0.016]}\end{array}$ & $\begin{array}{c}-0.008 \\
{[0.013]}\end{array}$ & $\begin{array}{c}-0.031 \\
{[0.017]^{*}}\end{array}$ \\
\hline Crises K-R $(\mathrm{T}+1)$ & $\begin{array}{c}-0.147 \\
{[0.040]^{* * *}}\end{array}$ & $\begin{array}{c}-0.213 \\
{[0.039]^{* * *}}\end{array}$ & $\begin{array}{c}-0.302 \\
{[0.282]}\end{array}$ & $\begin{array}{c}0.029 \\
{[0.007]^{* * *}}\end{array}$ & $\begin{array}{c}0.059 \\
{[0.016]^{* * *}}\end{array}$ & $\begin{array}{c}0.074 \\
{[0.011]^{* * *}}\end{array}$ \\
\hline Foreign*Crises K-R (T+1) & $\begin{array}{c}0.162 \\
{[0.071]^{* *}}\end{array}$ & $\begin{array}{c}0.059 \\
{[0.086]}\end{array}$ & $\begin{array}{c}0.049 \\
{[0.376]}\end{array}$ & $\begin{array}{c}0.007 \\
{[0.015]}\end{array}$ & $\begin{array}{c}-0.049 \\
{[0.020]^{* *}}\end{array}$ & $\begin{array}{l}-0.032 \\
{[0.021]}\end{array}$ \\
\hline $\begin{array}{l}\text { This table reports selected c } \\
\text { interest rates, across domest } \\
\text { during 1989-2001. Each col } \\
\text { the same set of (unreported) } \\
\text { reduce potential endogeneity } \\
1 \text { ", "T", and "T+1". Those } 1 \\
\text { year before financial crises } \\
\text { sensitivity analysis, three alt } \\
\text { Reinhart. These are reportec }\end{array}$ & $\begin{array}{l}\text { a set of } 18 \text { pan } \\
\text { anks, around pe } \\
\text { eparate regressi } \\
\text { trols: size, liqui } \\
\text { reported coeffi } \\
\text { equal one duri } \\
\text { ere, and "T+1" } \\
\text { ions of banking } \\
\text { middle-, and lov }\end{array}$ & $\begin{array}{l}\text { regressions } \\
\text { ods of financ } \\
\text { is that share t } \\
\text { ty, and capita } \\
\text { ients correspc } \\
\text { banking cris } \\
\text { qual one a ye } \\
\text { ises were use } \\
\text { r-panel, resp }\end{array}$ & $\begin{array}{l}\text { compare th } \\
\text { crises. The } \\
\text { ame depen } \\
\text { tion. Bank } \\
\text { to a set of } \\
\text { and zero els } \\
\text { fter bankin } \\
\text { Caprio-Kin } \\
\text { vely. }\end{array}$ & $\begin{array}{l}\text { e behavior of b } \\
\text { ample covers } \\
\text { lent variable, } d \\
\text { level controls v } \\
\text { ummy variable } \\
\text { where. Corres } \\
\text { crises, and zer } \\
\text { lebiel, Frankel }\end{array}$ & $\begin{array}{l}\text { ank loans, depo } \\
11 \text { Latin Americ } \\
\text { escribed in the } \\
\text { vere lagged one } \\
\text { s, generically la } \\
\text { pondingly, "T-1 } \\
\text { o elsewhere. Tc } \\
\text {-Rose, and Kan }\end{array}$ & $\begin{array}{l}\text { sits, and } \\
\text { can countries } \\
\text { first row, and } \\
\text { period to } \\
\text { abeled as "T- } \\
\text { " equal one a } \\
\text { o provide } \\
\text { ninsky- }\end{array}$ \\
\hline
\end{tabular}


Table 15. Asia, Alternative Crises Definitions

\begin{tabular}{|c|c|c|c|c|c|c|}
\hline & $\begin{array}{c}\text { [1] } \\
\text { Loan Growth }\end{array}$ & $\begin{array}{c}{[2]} \\
\text { Deposit } \\
\text { Growth } \\
\end{array}$ & $\begin{array}{c}3] \\
\text { Loans to } \\
\text { Deposits } \\
\end{array}$ & $\begin{array}{c}4] \\
\text { Bank Spread } \\
\end{array}$ & $\begin{array}{c}5] \\
\text { Deposit Rate }\end{array}$ & $\begin{array}{c}{[6]} \\
\text { Lending Rate } \\
\end{array}$ \\
\hline \multicolumn{7}{|c|}{ Caprio-Kinglebiel } \\
\hline Crises C-K (T-1) & $\begin{array}{c}0.008 \\
{[0.017]}\end{array}$ & $\begin{array}{c}-0.021 \\
{[0.021]}\end{array}$ & $\begin{array}{c}0.005 \\
{[0.062]}\end{array}$ & $\begin{array}{c}0.004 \\
{[0.002]^{* *}}\end{array}$ & $\begin{array}{c}0.003 \\
{[0.002]^{*}}\end{array}$ & $\begin{array}{c}0.008 \\
{[0.002]^{* * *}}\end{array}$ \\
\hline Foreign*Crises C-K (T-1) & $\begin{array}{c}-0.017 \\
{[0.037]}\end{array}$ & $\begin{array}{c}-0.065 \\
{[0.050]}\end{array}$ & $\begin{array}{c}-0.208 \\
{[0.187]}\end{array}$ & $\begin{array}{c}-0.004 \\
{[0.006]}\end{array}$ & $\begin{array}{c}0.011 \\
{[0.004]^{* *}}\end{array}$ & $\begin{array}{c}0.006 \\
{[0.008]}\end{array}$ \\
\hline Crises C-K (T) & $\begin{array}{c}-0.095 \\
{[0.018]^{* * *}}\end{array}$ & $\begin{array}{c}-0.086 \\
{[0.016]^{* * *}}\end{array}$ & $\begin{array}{c}-0.083 \\
{[0.061]}\end{array}$ & $\begin{array}{c}0.004 \\
{[0.002]}\end{array}$ & $\begin{array}{c}0.018 \\
{[0.002]^{* * *}}\end{array}$ & $\begin{array}{c}0.021 \\
{[0.002]^{* * *}}\end{array}$ \\
\hline Foreign*Crises C-K (T) & $\begin{array}{l}-0.015 \\
{[0.048]}\end{array}$ & $\begin{array}{l}-0.071 \\
{[0.044]}\end{array}$ & $\begin{array}{l}-0.217 \\
{[0.177]}\end{array}$ & $\begin{array}{c}-0.007 \\
{[0.006]}\end{array}$ & $\begin{array}{c}0.005 \\
{[0.004]}\end{array}$ & $\begin{array}{c}-0.001 \\
{[0.008]}\end{array}$ \\
\hline Crises C-K $(\mathrm{T}+1)$ & $\begin{array}{c}-0.15 \\
{[0.024]^{* * *}}\end{array}$ & $\begin{array}{c}-0.055 \\
{[0.020]^{* * *}}\end{array}$ & $\begin{array}{c}0.017 \\
{[0.101]}\end{array}$ & $\begin{array}{c}-0.008 \\
{[0.004]^{* *}}\end{array}$ & $\begin{array}{c}0.005 \\
{[0.001]^{* * *}}\end{array}$ & $\begin{array}{c}-0.003 \\
{[0.004]}\end{array}$ \\
\hline Foreign*Crises $\mathrm{C}-\mathrm{K}(\mathrm{T}+1)$ & $\begin{array}{c}-0.159 \\
{[0.057]^{* * *}}\end{array}$ & $\begin{array}{c}-0.102 \\
{[0.059]^{*}}\end{array}$ & $\begin{array}{c}-0.391 \\
{[0.169]^{* *}}\end{array}$ & $\begin{array}{c}-0.004 \\
{[0.005]}\end{array}$ & $\begin{array}{l}-0.005 \\
{[0.003]}\end{array}$ & $\begin{array}{l}-0.009 \\
{[0.006]}\end{array}$ \\
\hline \multicolumn{7}{|c|}{ Frankel-Rose } \\
\hline Crises F-R (T-1) & $\begin{array}{c}0.0230 \\
{[0.023]}\end{array}$ & $\begin{array}{l}-0.0260 \\
{[0.026]}\end{array}$ & $\begin{array}{c}0.0630 \\
{[0.096]}\end{array}$ & $\begin{array}{l}-0.0020 \\
{[0.002]}\end{array}$ & $\begin{array}{c}0.0050 \\
{[0.002]^{* * *}}\end{array}$ & $\begin{array}{c}0.0050 \\
{[0.002]^{* *}}\end{array}$ \\
\hline Foreign*Crises F-R (T-1) & $\begin{array}{c}0.0040 \\
{[0.043]}\end{array}$ & $\begin{array}{l}-0.0270 \\
{[0.065]}\end{array}$ & $\begin{array}{c}-0.7470 \\
{[0.210]^{* * *}}\end{array}$ & $\begin{array}{l}-0.0050 \\
{[0.006]}\end{array}$ & $\begin{array}{l}0.0030 \\
{[0.003]}\end{array}$ & $\begin{array}{l}-0.0040 \\
{[0.008]}\end{array}$ \\
\hline Crises F-R (T) & $\begin{array}{c}-0.1950 \\
{[0.025]^{* * *}}\end{array}$ & $\begin{array}{c}-0.1580 \\
{[0.028]^{* * *}}\end{array}$ & $\begin{array}{l}-0.0080 \\
{[0.081]}\end{array}$ & $\begin{array}{c}-0.0160 \\
{[0.002]^{* * *}}\end{array}$ & $\begin{array}{c}0.0310 \\
{[0.003]^{* * *}}\end{array}$ & $\begin{array}{c}0.0140 \\
{[0.003]^{* * *}}\end{array}$ \\
\hline Foreign*Crises F-R (T) & $\begin{array}{l}-0.0460 \\
{[0.048]}\end{array}$ & $\begin{array}{c}-0.1180 \\
{[0.048]^{* *}}\end{array}$ & $\begin{array}{c}-0.8810 \\
{[0.231]^{* * *}}\end{array}$ & $\begin{array}{l}0.0070 \\
{[0.005]}\end{array}$ & $\begin{array}{c}-0.0150 \\
{[0.003]^{* * *}}\end{array}$ & $\begin{array}{l}-0.0070 \\
{[0.006]}\end{array}$ \\
\hline Crises F-R $(\mathrm{T}+1)$ & $\begin{array}{c}-0.1840 \\
{[0.038]^{* * *}}\end{array}$ & $\begin{array}{c}-0.0990 \\
{[0.033]^{* * *}}\end{array}$ & $\begin{array}{l}-0.0950 \\
{[0.060]}\end{array}$ & $\begin{array}{c}-0.0130 \\
{[0.002]^{* * *}}\end{array}$ & $\begin{array}{c}0.0050 \\
{[0.002]^{* * *}}\end{array}$ & $\begin{array}{c}-0.0080 \\
{[0.003]^{* * *}}\end{array}$ \\
\hline Foreign*Crises F-R $(\mathrm{T}+1)$ & $\begin{array}{l}0.0820 \\
{[0.054]}\end{array}$ & $\begin{array}{l}-0.0120 \\
{[0.063]}\end{array}$ & $\begin{array}{l}-0.7050 \\
{[0.454]}\end{array}$ & $\begin{array}{c}0.0180 \\
{[0.015]}\end{array}$ & $\begin{array}{l}-0.0030 \\
{[0.004]}\end{array}$ & $\begin{array}{c}0.0150 \\
{[0.018]}\end{array}$ \\
\hline \multicolumn{7}{|c|}{ Kaminsky-Reinhart } \\
\hline Crises K-R (T-1) & $\begin{array}{c}0.038 \\
{[0.020]^{*}}\end{array}$ & $\begin{array}{c}0.005 \\
{[0.024]}\end{array}$ & $\begin{array}{c}0.06 \\
{[0.075]}\end{array}$ & $\begin{array}{c}0.002 \\
{[0.001]}\end{array}$ & $\begin{array}{c}0.009 \\
{[0.002]^{* * *}}\end{array}$ & $\begin{array}{c}0.012 \\
{[0.002]^{* * *}}\end{array}$ \\
\hline Foreign*Crises K-R (T-1) & $\begin{array}{c}0.007 \\
{[0.041]}\end{array}$ & $\begin{array}{l}-0.033 \\
{[0.052]}\end{array}$ & $\begin{array}{l}-0.279 \\
{[0.189]}\end{array}$ & $\begin{array}{c}0.001 \\
{[0.005]}\end{array}$ & $\begin{array}{c}0.006 \\
{[0.004]}\end{array}$ & $\begin{array}{c}0.006 \\
{[0.007]}\end{array}$ \\
\hline Crises K-R (T) & $\begin{array}{c}-0.122 \\
{[0.027]^{* * *}}\end{array}$ & $\begin{array}{c}-0.048 \\
{[0.024]^{* *}}\end{array}$ & $\begin{array}{l}-0.049 \\
{[0.054]}\end{array}$ & $\begin{array}{c}-0.004 \\
{[0.002]^{*}}\end{array}$ & $\begin{array}{c}0.039 \\
{[0.004]^{* * *}}\end{array}$ & $\begin{array}{c}0.032 \\
{[0.002]^{* * *}}\end{array}$ \\
\hline Foreign*Crises K-R (T) & $\begin{array}{c}0.066 \\
{[0.055]}\end{array}$ & $\begin{array}{l}-0.057 \\
{[0.050]}\end{array}$ & $\begin{array}{c}-0.315 \\
{[0.190]^{*}}\end{array}$ & $\begin{array}{c}0.004 \\
{[0.007]}\end{array}$ & $\begin{array}{c}-0.012 \\
{[0.005]^{* *}}\end{array}$ & $\begin{array}{l}-0.005 \\
{[0.008]}\end{array}$ \\
\hline Crises K-R $(\mathrm{T}+1)$ & $\begin{array}{c}-0.225 \\
{[0.035]^{* * *}}\end{array}$ & $\begin{array}{c}-0.106 \\
{[0.032]^{* * *}}\end{array}$ & $\begin{array}{c}0.028 \\
{[0.058]}\end{array}$ & $\begin{array}{c}-0.011 \\
{[0.003]^{* * *}}\end{array}$ & $\begin{array}{c}0.02 \\
{[0.003]^{* * *}}\end{array}$ & $\begin{array}{c}0.01 \\
{[0.003]^{* * *}}\end{array}$ \\
\hline Foreign*Crises K-R $(\mathrm{T}+1)$ & $\begin{array}{c}-0.115 \\
{[0.056]^{* *}}\end{array}$ & $\begin{array}{c}-0.209 \\
{[0.058]^{* * *}}\end{array}$ & $\begin{array}{c}-0.339 \\
{[0.155]^{* *}}\end{array}$ & $\begin{array}{c}0.003 \\
{[0.005]}\end{array}$ & $\begin{array}{c}-0.01 \\
{[0.004]^{* * *}}\end{array}$ & $\begin{array}{l}-0.008 \\
{[0.006]}\end{array}$ \\
\hline $\begin{array}{l}\text { This table reports selected c } \\
\text { interest rates, across domest } \\
2001 \text {. Each column covers } 3 \\
\text { of (unreported) bank-level c } \\
\text { endogeneity problems. The } \\
\text { "T+1". Those labeled with " } \\
\text { financial crises and zero els } \\
\text { analysis, three alternative de } \\
\text { are reported in the upper-, } \mathrm{m}\end{array}$ & $\begin{array}{l}\text { a set of } 18 \text { pan } \\
\text { anks, around pe } \\
\text { sions that share } \\
\text { uidity, and capi } \\
\text { ents correspon } \\
\text { ring banking cr } \\
\text { 1" equal one a } \\
\text { ing crises were } \\
\text { r-panel, respec }\end{array}$ & $\begin{array}{l}\text { regressions t } \\
\text { ods of financ } \\
\text { he same depe } \\
\text { lization. Ban } \\
\text { to a set of dul } \\
\text { es and zero e } \\
\text { ear after bank } \\
\text { used: Caprio- } \\
\text { vely. }\end{array}$ & $\begin{array}{l}\text { at compare th } \\
1 \text { crises. The } \\
\text { dent variable, } \\
\text {-level control } \\
\text { my variables, } \\
\text { ewhere. Corr } \\
\text { ig crises, and } \\
\text { inglebiel, Fra }\end{array}$ & $\begin{array}{l}\text { behavior of } b \\
\text { ample covers } \\
\text { described in th } \\
\text { were lagged o } \\
\text { generically lab } \\
\text { espondingly, "1 } \\
\text { zero elsewhere } \\
\text { kel-Rose, and }\end{array}$ & $\begin{array}{l}\text { nk loans, depc } \\
\text { Asian countri } \\
\text { first row, and } \\
\text { ne period to re } \\
\text { led as "T-1", } \\
-1 \text { " equal one } \\
\text { To provide se } \\
\text { Kaminsky-Rei }\end{array}$ & $\begin{array}{l}\text { sits, and } \\
\text { es during 1989- } \\
\text { the same set } \\
\text { duce potential } \\
\text { 'T", and } \\
\text { year before } \\
\text { nsitivity } \\
\text { hart. These }\end{array}$ \\
\hline
\end{tabular}




\section{APPENDIX 1. SCALES FOR RESERVE REQUIREMENTS BY COUNTRY}

I.

SCALE

IF RESERVE REQUIREMENT IS:

BETWEEN 1\% AND 15\%:

BETWEEN 16\% AND 30\%:

BETWEEN $31 \%$ AND $70 \%$ :

BETWEEN $71 \%$ AND $100 \%$ :

SUB- CATEGORIES:

BETWEEN 1\% AND 15\%

$\begin{array}{rr}1.00 \% & 1.00 \\ 3.00 \% & 1.20 \\ 4.50 \% & 1.30 \\ 6.00 \% & 1.40 \\ 7.50 \% & 1.50 \\ 9.00 \% & 1.60 \\ 10.50 \% & 1.70 \\ 12.00 \% & 1.80 \\ 13.50 \% & 1.90 \\ 15.00 \% & 1.99\end{array}$

$1-2$
$2-3$
$3-4$
$4-5$

BETWEEN 16\% AND 30\%

$\begin{array}{cccc}\text { BWEEN } 16 \% & \text { AND 30\% } & \text { BETWEEN 31\% AND 70\% } \\ 16.00 \% & 2.00 & 31 \% & 3.00 \\ 19.50 \% & 2.25 & 40 \% & 3.25 \\ 23.00 \% & 2.50 & 50 \% & 3.50 \\ 25.00 \% & 2.60 & 60 \% & 3.75 \\ 26.50 \% & 2.75 & 70 \% & 3.99\end{array}$

BETWEEN $71 \%$ AND $100 \%$

$\begin{array}{rr}71 \% & 4.00 \\ 80 \% & 4.30 \\ 85 \% & 4.50 \\ 90 \% & 4.60 \\ 100 \% & 4.99\end{array}$

EXAMPLES THAT CAN BE EXTENDED FOR OTHER CASES:

$\begin{array}{rrrr}9.00 \% & 1.60 & 10.50 \% & 1.70 \\ 9.25 \% & 1.62 & 10.75 \% & 1.72 \\ 9.50 \% & 1.64 & 11.00 \% & 1.74 \\ 9.75 \% & 1.65 & 11.25 \% & 1.75 \\ 10.00 \% & 1.67 & 11.50 \% & 1.77 \\ 10.25 \% & 1.69 & 11.75 \% & 1.79 \\ 10.50 \% & 1.70 & 12.00 \% & 1.80\end{array}$

II. HOW DO WE ASSIGN THE FINAL SCALE?

1) For each country, we specify the policy instrument used to construct the reserve requirement index. Most cases use the reserve requirement on demand deposits (first criterium).

2) During years with one or more changes in reserve requirements, the index reflects the weighted average of its intra-year values, using the relative time of the policy regimes as weights.

3) In cases where reserve requirements on demand deposits in domestic currency were not applicable, or did not show variation, a parallel policy instrument (such as liquidity requirements, reserve requirements on foreign currency deposits, etc.) was also used (second criterium). The list of policy instruments used for each country is presented in Appendix 2. 
APPENDIX 2. CRITERIA FOR THE CONSTRUCTION OF THE RESERVE REQUIREMENTS INDEX

ARGENTINA

First Criterium:

Reserve requirements (minimum cash requirement) until 1994

Minimum liquidity requirements since 1995

Second Criterium:

Reserve requirements for deposits in foreign currency.

BOLIVIA

First Criterium:

Reserve requirement on demand deposits (domestic currency).

BRAZIL

First Criterium:

Reserve requirement on demand deposits (domestic currency).

Second Criterium:

Reserve requirements for saving and time deposits in domestic currency, and

daily balance to be held in banking reserves.

CHILE

First Criterium:

Reserve requirements on demand deposits (foreign currency).

Second Criterium:

Reserve requirement on external credits.

COLOMBIA

First Criterium:

Reserve requirement on demand deposits (domestic currency)

Second Criterium:

Reserve requirements for saving and time deposits in domestic currency.

INDIA

First Criterium:

Cash reserve requirement on demand deposits (domestic currency).

Second Criterium:

Statutory liquidity ratio on demand and time liabilities.

INDONESIA

First Criterium:

Statutory reserve requirement on demand deposits (domestic currency)

Second Criterium:

Statutory reserve requirement on foreign currency deposits.

\section{KOREA}

First Criterium:

Reserve requirement on demand deposits (domestic currency).

Second Criterium:

Marginal reserve requirement in domestic and foreign currency. 
MALAYSIA

First Criterium:

Statutory reserve requirement on demand deposits (domestic currency).

Second Criterium

Liquidity requirement.

MEXICO

First Criterium:

Reserve requirement on demand deposits (domestic currency) until 1988.

Liquidity coeffcient from 1989 to 1990.

Liquidity coeffcient for deposits in foreign currency 1991 (August) to 1994.

PARAGUAY

First Criterium:

Reserve requirement on demand deposits (domestic currency).

PERU

First Criterium:

Reserve requirement (domestic currency).

Second Criterium:

Reserve requirements for deposits in foreign currency.

PHILIPPINES

\section{First Criterium:}

Reserve requirement on demand deposits (domestic currency). The reserve requirement

against peso demand is the sum of the statutory and the liquidity reserve ratios.

SINGAPORE

First Criterium:

Minimum cash balance on demand deposits (domestic currency).

TAIWAN

First Criterium:

Reserve requirement ratio on demand deposits (domestic currency).

Second Criterium:

The required reserve ratio for passbook saving deposits, time saving deposits and time deposits.

THAILAND

First Criterium

Liquidity requirement ratio on demand deposits (domestic currency).

\section{Second Criterium:}

Minimum reserve requirement on non-resident bath deposits.

URUGUAY

First Criterium:

The remunerated reserve requirement on sight deposits in local currency.

VENEZUELA

First Criterium:

Reserve requirement on demand deposits (domestic currency). 
APPENDIX 3. RESERVE REQUIREMENTS INDEX

\begin{tabular}{|c|c|c|}
\hline 1986 & 4.580 & Reserve requirements were kept at $89,5 \%$ on demand deposits. \\
\hline 1990 & 4.575 & $\begin{array}{l}\text { As from July, reserve requirements were reduced } 3 \% \text { in cases of technical reserves for demand deposits and } \\
\text { by } 1.5 \% \text { additional for fixed time deposits. By September, the contractionary monetary policy was further deepened, so } \\
\text { the backing figures returned to their previous high levels. }\end{array}$ \\
\hline 1991 & 4.555 & In December, the Central Bank reduced minimum cash requirements to $79 \%$ on demand deposits. \\
\hline 1992 & 4.120 & $\begin{array}{l}\text { There were not substancial variations in minimum cash requirements. Requirements on deposits } \\
\text { whose holders belonged to the non-financial public sector were reduced by } 6 \% \text {. As of October } 1 \\
\text { the Central Bank reduced by } 2 \% \text { the minimun cash requirement on peso deposits in current accounts } \\
\text { and other sight and fixed term operations, at } 71 \% \text {. }\end{array}$ \\
\hline 1993 & 3.354 & $\begin{array}{l}\text { The Central Bank homogenized the reserve requirements for current accounts and sight operations in both } \\
\text { currencies, implying a substantial reduction in reserve requirements for current accounts in pesos from } 71 \% \text { to } 40 \% \text {. } \\
\text { In August, the Central Bank set a 3\% increase, to } 43 \% \text {, in cash requirements on current account and saving deposits. }\end{array}$ \\
\hline 1994 & 3.300 & $\begin{array}{l}\text { The Central Bank reduced temporarily required minimums covering dollars deposits from } 43 \% \text { for sight deposits dated } \\
12-15-95 \text {, to } 35 \% \text { until } 1-15-95 \text {. For fixed-term deposits the minimum cash requirement dropped from } 3 \% \text { to } 1 \% \text { as of } \\
12-16-94 \text { to be reestablished at } 3 \% \text { as of } 2-1-95 \text {. }\end{array}$ \\
\hline 1995 & 3.082 & $\begin{array}{l}\text { As of November 1995, reserve requirements have been replaced by minimum liquidity requirements (Requisitos Minimos } \\
\text { de Liquidez), which may include earning assets. All deposits were subject to a uniform } 15 \% \text { liquidity requirement. }\end{array}$ \\
\hline 1996 & 2.100 & The Central Bank increased the minimum liquidity requirement by $2 \%$. \\
\hline 1997 & 2.200 & The Central Bank increased the minimum liquidity requirement by $2 \%$. \\
\hline 1998 & 2.300 & The Central Bank increased the minimum liquidity requirement by $1 \%$. \\
\hline 2001 & 2.188 & $\begin{array}{l}\text { In April, the Central Bank reduced the minimum liquidity requirement by } 2 \% \text {. } \\
\text { In June, the Central Bank established a new liquidity regime based on a minimum cash requirement over sight } \\
\text { operations, whereas the rules realted to minimum liquidity requirements only involved fixed term deposits. }\end{array}$ \\
\hline
\end{tabular}

Source: Annual Report of the Argentine Economy- Economic Trends. Consejo Tecnico de Inversiones.

\section{BOLIVIA}

Year Code Reserve Requirements

19853.500 Central Bank reduced reserve requirements on demand deposits, saving deposits and time deposits, all in domestic currency. From $60 \%$ to $50 \%$ in the case of demand deposits.

$19863.250 \quad$ Central Bank reduced reserve requirements on demand deposits, saving deposits and time deposits, all in domestic currency. From $50 \%$ to $40 \%$ in the case of demand deposits.

19872.765 In July. Central Bank homogenized the reserve requirements to $20 \%$ for different types of deposits and currencies

19941.975 In July, the Central Bank eliminated the marginal reserve requirement for deposits in domestic currency.

The marginal reserve requirement was $10 \%$ for demand and saving deposits, and $6 \%$ for time deposits (less than 365 days).

19981.757 In May, Central Bank homogenized the reserve requirements to $12 \%$ for different types of deposits and currencies.

Source: Annual Reports of the Central Bank of Bolivia.

BRAZIL

Year Code Reserve Requirements

$19843.300 \quad$ The Central Bank increased reserve requirements from $10 \%$ to $22 \%$ for time deposits. The average reserve requirement on der deposits was $43 \%$.

19853.170 The rate of reserve requirements on demand deposits in the commercial banks dropped from an average of $43 \%$ to $36 \%$.

$19883.180 \quad$ Reserve requirements are rationalized, requirements differing according to bank size. As of December, the average implicit reserve requirement represented $37 \%$ of deposits.

$1993 \quad 3.458$ The percentage of the reserve requirement moved from $40 \%$ to $50 \%$ but had little impact on the banking system's capacity to grant credit, since demand deposits represented less than $1 \%$ of GDP.

19944.337 Under the Real Plan, the Central Bank raised the reserve requirement on demand deposits to $100 \%$ in June, which was reduce to $90 \%$ in December. The reserve requeriment on time deposits was raised from $20 \%$ to $30 \%$ in August and then reduced to $27 \%$ in December. For saving deposits, the reserve requirement was raised from $20 \%$ to $30 \%$ in August.

19954.500 The reserve requirement on demand deposits was reduced from $90 \%$ to $83 \%$ in July, for time deposits the rate was reduced to $20 \%$ in August, and for saving deposits the rate was reduced to $15 \%$.

19964.200 The criteria for reserve requirements and obligatory reserves on demand deposits were altered and a schedule was defined according to which the rate would gradually decline from $83 \%$ to $78 \%$ as of December.

19974.150 In January, the reserve requirement on demand deposits was reduced from $78 \%$ to $75 \%$.

19994.075 In October, the reserve requirement on demand deposits was reduced from $75 \%$ to $65 \%$.

20003.538 The reserve requirement on demand deposits was reduced twice during the year to $55 \%$ in March and to $45 \%$ in June. 


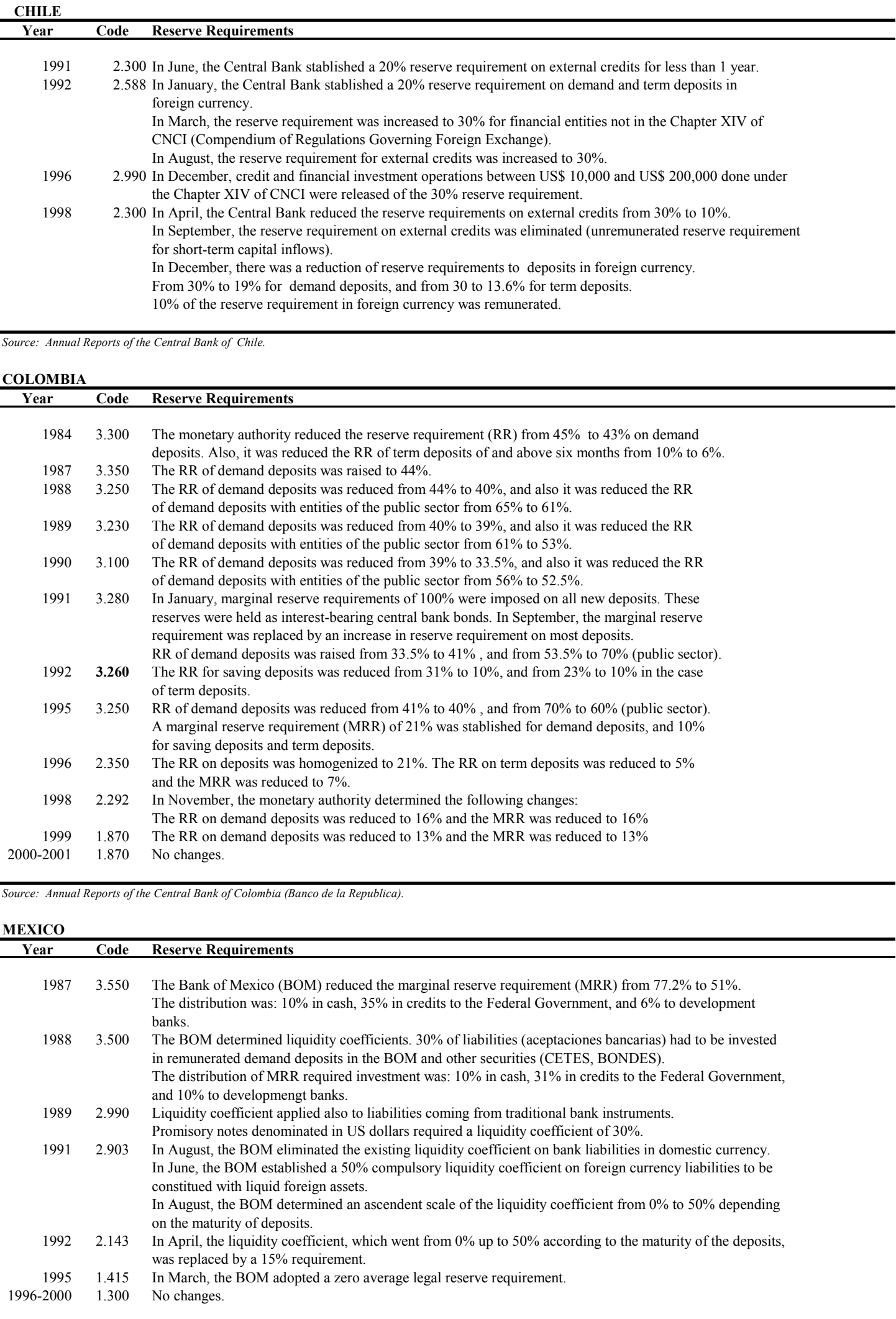

Source: Annual Reports of the Central Bank of Mexico (Banco de Mexico). 
PARAGUAY

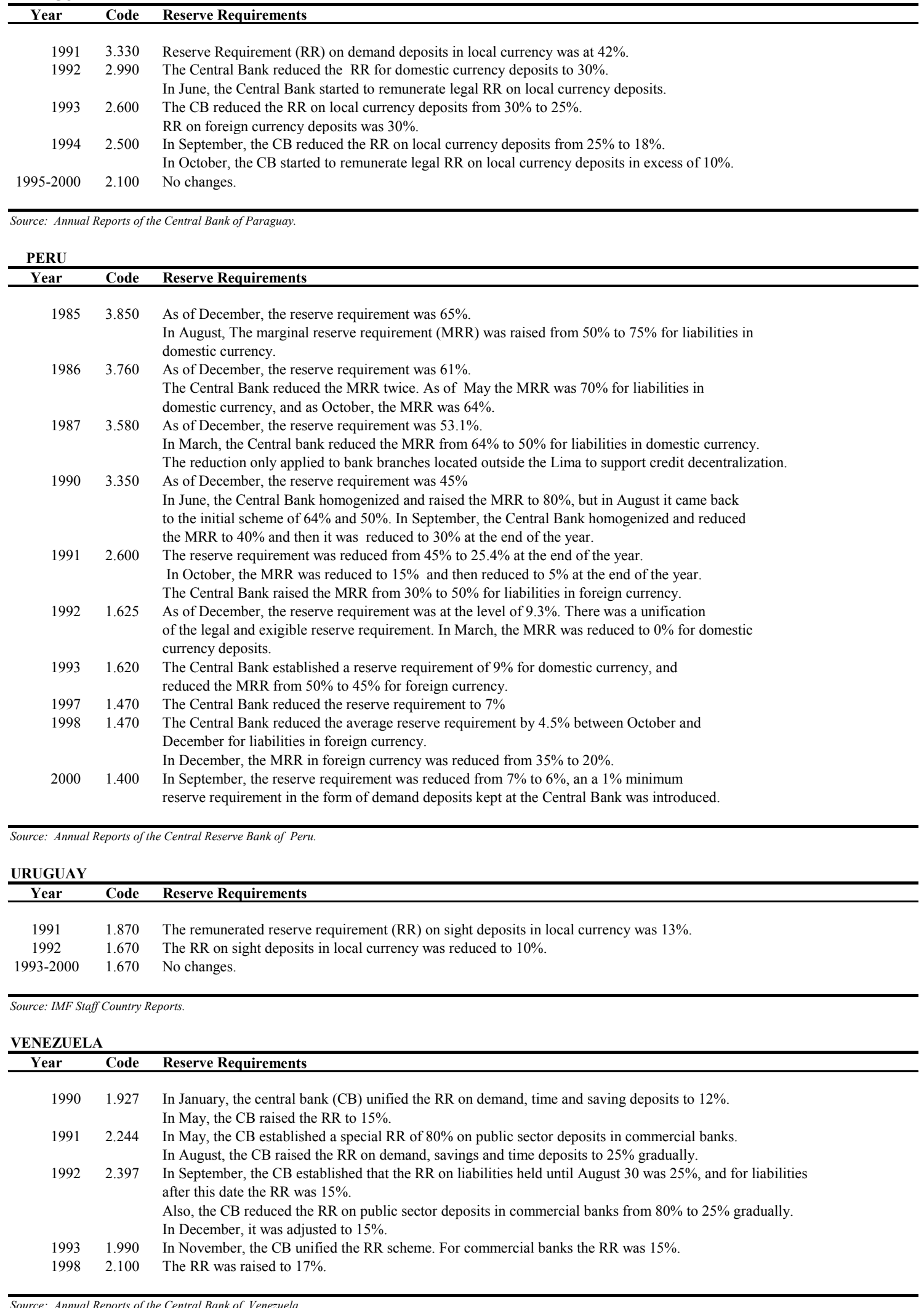

Source: Annual Reports of the Central Bank of Venezuela. 
INDIA

\begin{tabular}{|c|c|c|}
\hline Year & Code & Reserve Requirements \\
\hline 1987 & 1.644 & In February, the cash reserve requirement (CRR) was raised from $9 \%$ to $9.5 \%$. \\
\hline & & In May, the CRR on foreign currency non-resident (FCNR) deposit liabilities was raised from $3 \%$ to $9.5 \%$. \\
\hline & & In October, the CRR was raised from $9.5 \%$ to $10 \%$ of net demand and time liabilities. \\
\hline 1988 & 1.705 & $\begin{array}{l}\text { In July, the CRR was raised from } 10 \% \text { to } 11 \% \text { of net demand and time liabilities. } \\
\text { In July, the CRR on FCNR was raised from } 9.5 \% \text { to } 10 \% \text {. }\end{array}$ \\
\hline 1989 & 1.866 & In July, the CRR was homogenized at $15 \%$ for all net demand and time liabilities. \\
\hline 1990 & 1.992 & In September, statutory liquidity ratio (SLR) was raised from $38 \%$ to $38.5 \%$ of net demand and time liabilities. \\
\hline 1992 & 1.980 & $\begin{array}{l}\text { In April, SLR was reduced from } 38.5 \% \text { to } 37.75 \% \text { of net demand and time liabilities. } \\
\text { In April, banks were exempted from the mantainance of the } 10 \% \text { incremental CRR on net } \\
\text { demand and time liabilities. }\end{array}$ \\
\hline 1993 & 1.973 & In September, CRR was reduced from $15 \%$ to $14 \%$. \\
\hline 1994 & 1.990 & $\begin{array}{l}\text { CRR was raised from } 14 \% \text { to } 15 \% \text { in three phases. } \\
\text { In October, a CRR of } 7.5 \% \text { on FCNR deposit liabilities was stablished. }\end{array}$ \\
\hline 1995 & 1.982 & $\begin{array}{l}\text { In January, CRR of deposit liabilities under Foreign Currency (NR) was raised to } 15 \% \text {. } \\
\text { In November and December, the CRR was reduced from } 15 \% \text { to } 14 \% \text {. }\end{array}$ \\
\hline 1996 & 1.848 & $\begin{array}{l}\text { In May, the CRR was reduced from } 14 \% \text { to } 13 \% \text {. } \\
\text { In July, the CRR was reduced from } 13 \% \text { to } 12 \% \text {. } \\
\text { In November, the CRR was reduced from } 12 \% \text { to } 11 \% \text {. }\end{array}$ \\
\hline 1997 & 1.665 & $\begin{array}{l}\text { In January, the CRR was reduced from } 11 \% \text { to } 10 \% \text {. } \\
\text { In October, the CRR was reduced from } 10 \% \text { to } 9.75 \% \text {. }\end{array}$ \\
\hline 1998 & 1.683 & In March, the CRR was raised from $9.75 \%$ to $10.25 \%$. \\
\hline 1999 & 1.675 & In November, the CRR was reduced from $10.25 \%$ to $9 \%$. \\
\hline
\end{tabular}

Source: Annual Reports of the Central Bank of India.

\section{INDONESIA}

\begin{tabular}{|c|c|c|}
\hline Year & Code & Reserve Requirements \\
\hline 1988 & 1.100 & Reserve requirements were reduced from $15 \%$ to $2 \%$. \\
\hline 1995 & 1.100 & $\begin{array}{l}\text { In December, the Bank of Indonesia (BOI) amended the regulation on the reserve requirement to statutory } \\
\text { reserve requirement. With this new regulation, the reserve components changed from demand deposits } \\
\text { with BOI and cash originally, to only demand deposit with BOI. }\end{array}$ \\
\hline 1996 & 1.192 & $\begin{array}{l}\text { In February, the new regulation required commercial banks to maintain } 3 \% \text { of their funds in the form of } \\
\text { demand deposit with the BOI. }\end{array}$ \\
\hline 1997 & 1.192 & The statutory reserve requirement for foreign currencies deposits was reduced from $5 \%$ to $3 \%$. \\
\hline
\end{tabular}

Source: Annual Reports of the Bank of Indonesia.

KOREA

\begin{tabular}{|c|c|c|}
\hline Year & Code & Reserve Requirements \\
\hline 1985 & 1.300 & $\begin{array}{l}\text { the reserve requirement (RR) for demand, time and saving deposits was } 4,5 \% \text { in domestic currency and } 1 \% \text { in foreign } \\
\text { currency ( In July, the marginal reserve ratio for resident account in foreign currency was introduced at } 20 \% \text { ). }\end{array}$ \\
\hline 1987 & 1.328 & $\begin{array}{l}\text { In November, RR for demand, time and saving deposits was raised to } 7.0 \% \text { in domestic currency. } \\
\text { In February, the marginal reserve ratio for resident account in foreign currency was reduced to } 4.5 \% \text {. }\end{array}$ \\
\hline 1988 & 1.486 & In December, RR for demand, time and saving deposits was raised to $10.0 \%$ in domestic currency. \\
\hline 1989 & 1.680 & In May, a 30\% marginal reserve requirement (MRR) was introduced for deposits in domestic currency. \\
\hline 1990 & 1.762 & $\begin{array}{l}\text { In February, RR for demand, time and saving deposits was raised to } 11.5 \% \text { in domestic currency. } \\
\text { In March, the marginal reserve ratio for resident account in foreign currency was raised to } 11.5 \% \text {. }\end{array}$ \\
\hline 1996 & 1.621 & $\begin{array}{l}\text { In April, RR for demand, time and saving deposits was reduced to } 9 \% \text { in domestic currency } \\
\text { In April, the marginal reserve ratio for resident account in foreign currency was reduced to } 9 \% \text {. } \\
\text { In November, RR for demand, time and saving deposits was reduced to } 7 \% \text { in domestic currency. } \\
\text { In November, the marginal reserve ratio for resident accounts in foreign currency was reduced to } 7 \% \text {. }\end{array}$ \\
\hline 1997 & 1.351 & $\begin{array}{l}\text { In February, RR for demand deposits was reduced to } 5 \% \text { in domestic currency. The RR for time and saving } \\
\text { deposits in domestic currency was reduced to } 2 \% \text {. }\end{array}$ \\
\hline 2000 & 1.340 & $\begin{array}{l}\text { The Bank of Korea imposed a } 2 \% \text { RR on negotiable certificates of deposits. } \\
\text { In April, the MRR for resident account in foreign currency (demand deposits) was reduced to } 5 \% \text {. The MRR } \\
\text { for resident account in foreign currency (time and saving deposits) was reduced to } 2 \% \text {. }\end{array}$ \\
\hline
\end{tabular}


MALAYSIA

\begin{tabular}{|c|c|c|}
\hline Year & Code & Reserve Requirements \\
\hline 1985 & 1.288 & $\begin{array}{l}\text { In April, the statutory reserve requeriment (SRR) of commercial banks (CB) was reduced from } \\
5 \% \text { to } 4 \% \text { of total eligible liabilities. For merchant banks (MB), the ratio was raised from } 1.5 \%\end{array}$ \\
\hline 1986 & 1.263 & $\begin{array}{l}\text { to } 2.5 \% \text {. The SRR for finance companies (FC) remained unchanged at } 2.5 \% \text {. } \\
\text { In February, the SRR of } \mathrm{FC} \text { and MB as increased from } 2.5 \% \text { to } 3 \% \text {. } \\
\text { In October, the SRR for CB was reduced from } 4 \% \text { to } 3.5 \% \text {. }\end{array}$ \\
\hline & & In February, the liquidity requeriment (LR) of CB was reduced from $20 \%$ to $18.5 \%$. The LR for \\
\hline & & $\mathrm{MB}$ and $\mathrm{FC}$ remained unchanged at $10 \%$. \\
\hline & & In October, the LR for CB was reduced from $18.5 \%$ to $17 \%$. \\
\hline 1987 & 1.238 & $\begin{array}{l}\text { The Central Bank reduced the liquidity ratio of } \mathrm{CB} \text { from } 10 \% \text { to } 8 \% \text {, with the LR remaining } \\
\text { unchanged at } 17 \% \text { for } \mathrm{MB} \text { and } \mathrm{FC} \text {. }\end{array}$ \\
\hline 1988 & 1.233 & $\begin{array}{l}\text { The Central Bank reduced the liquidity ratio of } \mathrm{CB} \text { from } 8 \% \text { to } 5 \% \text {, and abolished the liquidity } \\
\text { ratio for FC. }\end{array}$ \\
\hline 1989 & 1.298 & $\begin{array}{l}\text { In May, the Central Bank raised the SRR of } \mathrm{CB}, \mathrm{MB} \text { and } \mathrm{FC} \text { to a uniform } 4.5 \% \text {. } \\
\text { In October, the Central Bank raised the SRR of } \mathrm{CB}, \mathrm{MB} \text { and } \mathrm{FC} \text { to } 5.5 \% \text {. }\end{array}$ \\
\hline 1990 & 1.440 & In January, the Central Bank raised the SRR of $\mathrm{CB}, \mathrm{MB}$ and $\mathrm{FC}$ to $6.5 \%$. \\
\hline 1991 & 1.465 & In August, the Central Bank raised the SRR of $\mathrm{CB}, \mathrm{MB}$ and $\mathrm{FC}$ to $7.5 \%$. \\
\hline 1992 & 1.547 & In May, the Central Bank raised the SRR of $\mathrm{CB}, \mathrm{MB}$ and $\mathrm{FC}$ to $8.5 \%$. \\
\hline 1994 & 1.715 & $\begin{array}{l}\text { In January, the Central Bank raised the SRR of } \mathrm{CB}, \mathrm{MB} \text { and } \mathrm{FC} \text { to } 9.5 \% \text {. } \\
\text { In May, the Central Bank raised the SRR of } \mathrm{CB}, \mathrm{MB} \text { and } \mathrm{FC} \text { to } 10.5 \% \text {. } \\
\text { In July, the Central Bank raised the SRR of } \mathrm{CB}, \mathrm{MB} \text { and } \mathrm{FC} \text { to } 11.5 \% \text {. }\end{array}$ \\
\hline 1996 & 1.873 & $\begin{array}{l}\text { In February, the Central Bank raised the SRR of } \mathrm{CB}, \mathrm{MB} \text { and } \mathrm{FC} \text { to } 12.5 \% \text {. } \\
\text { In June, the Central Bank raised the SRR of } \mathrm{CB}, \mathrm{MB} \text { and } \mathrm{FC} \text { to } 13.5 \% \text {. }\end{array}$ \\
\hline 1998 & 1.521 & $\begin{array}{l}\text { In February, the Central Bank reduced the SRR of CB, MB and FC from } 13.5 \% \text { to } 10 \% \text {. } \\
\text { In July, the Central Bank reduced the SRR of } \mathrm{CB}, \mathrm{MB} \text { and } \mathrm{FC} \text { from } 10 \% \text { to } 8 \% \text {. } \\
\text { In September, the Central Bank reduced the SRR of CB, MB and FC from } 8 \% \text { to } 4 \% \text {. }\end{array}$ \\
\hline $1999-2000$ & 1.250 & No changes. \\
\hline
\end{tabular}

Source: Annual Reports of the Central Bank of Malaysia.

PHILIPPINES

\begin{tabular}{|c|c|c|}
\hline Year & Code & Reserve Requirements \\
\hline 1985 & 2.540 & $\begin{array}{l}\text { In September, the reserve requirement (RR) against short-term deposit liabilities of } \\
\text { commerical banks (CB) and thrift banks (TB) was reduced from } 24 \% \text { to } 23 \% \text {. }\end{array}$ \\
\hline 1986 & 2.438 & $\begin{array}{l}\text { The RR on long-term deposit instruments of banks was reduced by a total of } 2 \\
\text { percentage points from } 23 \% \text { to } 21 \% \text { in May and August. }\end{array}$ \\
\hline 1987 & 2.350 & No changes. \\
\hline 1988 & 2.350 & No changes. \\
\hline 1989 & 2.333 & In September, the RR on deposits and deposit substitutes was homogenized to $20 \%$. \\
\hline 1990 & 2.600 & $\begin{array}{l}\text { A series of upward adjustments in the RR on bank deposits were made during the } \\
\text { year with a cummulative increase of } 5 \text { percentage points from } 20 \% \text { in } 1989 \text { to } 25 \% \text { at the } \\
\text { end of } 1990 \text { as a contractionary measure. }\end{array}$ \\
\hline 1991 & 2.600 & No changes. \\
\hline 1992 & 2.600 & No changes. \\
\hline 1993 & 2.300 & $\begin{array}{l}\text { A series of downward adjustments in the RR on bank deposits were made during the } \\
\text { year with a cummulative reduction of } 5 \text { percentage points from } 25 \% \text { in } 1992 \text { to } 22 \% \text { at the } \\
\text { end of } 1993 \text {. }\end{array}$ \\
\hline 1994 & 2.100 & The RR was reduced to $19 \%$. \\
\hline 1995 & 2.027 & In May, the RR was reduced to $17 \%$. \\
\hline 1997 & 2.100 & $\begin{array}{l}\text { At the end of the year, the RR was } 17 \% \text {. During the year there were seven changes in the } \\
\text { liquidity reserve component of the RR. }\end{array}$ \\
\hline 1998 & 2.054 & In May, the RR was reduced to $15 \%$. In October, the RR was increased to $17 \%$. \\
\hline 1999 & 1.950 & The RR was reduced during the year by a total of 5 percentage points from $17 \%$ in January to reach $12 \%$ by July. \\
\hline 2000 & 1.850 & In October, the RR was increased to $16 \%$. \\
\hline
\end{tabular}


SINGAPORE

\begin{tabular}{|c|c|c|}
\hline Year & Code & Reserve Requirements \\
\hline 1987 & 1.400 & $\begin{array}{l}\text { In May, the Monetary Authority of Singapore (MAS) reduced the minimum liquid asset ratio from } \\
20 \% \text { to } 18 \% \text {. }\end{array}$ \\
\hline 1998 & 1.300 & $\begin{array}{l}\text { In July, the MAS reduced the minimum cash balance (MCB) from } 6 \% \text { to } 3 \% \text {. The MCB had been } \\
\text { mantained at } 6 \% \text { since } 1975 \text {. }\end{array}$ \\
\hline $1999-2000$ & 1.200 & $\begin{array}{l}\text { The minimum liquid assets (MLA) requirement of finance companies was raised from } 10 \% \text { to } 13 \% \text {. } \\
\text { No changes. }\end{array}$ \\
\hline \multicolumn{3}{|c|}{ Source: Annual Reports of the Monetary Authority of Singapore. } \\
\hline \multicolumn{3}{|l|}{ TAIWAN } \\
\hline Year & Code & Reserve Requirements \\
\hline 1978 & 2.990 & The required reserve ratio (RRR) for checking accounts (CA) was $30 \%$ \\
\hline 1979 & 2.730 & In May, the RRR for CA was reduced to $25 \%$. \\
\hline 1982 & 2.542 & In June, the RRR for CA was reduced to $23 \%$. \\
\hline 1988 & 2.508 & In December, the RRR for CA was raised to $25 \%$. \\
\hline 1989 & 2.863 & In April, the RRR for CA was raised to $29 \%$. \\
\hline 1990 & 2.929 & In August, the RRR for CA was reduced to $28.5 \%$. \\
\hline 1991 & 2.867 & In September, the RRR for CA was reduced to $27.75 \%$. \\
\hline 1993 & 2.773 & In September, the RRR for CA was reduced to $26.25 \%$. \\
\hline 1995 & 2.692 & In November, the RRR for CA was reduced to $23.75 \%$. \\
\hline 1996 & 2.508 & In August, the RRR for CA was reduced to $22 \%$. \\
\hline 1997 & 2.408 & In October, the RRR for CA was reduced to $19.75 \%$. \\
\hline 1998 & 2.247 & In September, the RRR for CA was reduced to $18.75 \%$. \\
\hline 1999 & 2.006 & In February, the RRR for CA was reduced to $15 \%$. \\
\hline 2000 & 1.975 & In October, the RRR for CA was reduced to $13.5 \%$. \\
\hline 2001 & 1.855 & In October, the RRR for CA was reduced to $10.75 \%$. \\
\hline \multicolumn{3}{|c|}{ THAILAND } \\
\hline Year & Code & Reserve Requirements \\
\hline 1990 & 1.470 & $\begin{array}{l}\text { To stabilize the money markets and reduce fluctuations of short-term interest rates, the BOT } \\
\text { modified the computacional procedure of commercial bank's reserve requirements. }\end{array}$ \\
\hline 1995 & 1.480 & $\begin{array}{l}\text { In August, non-resident bath deposits with maturity of less than one year are subject to a } 7 \% \\
\text { minimum reserve requirement in the form of deposits (with no interest) with the BOT. } \\
\text { While reserve requirements on domestic deposits were also } 7 \% \text {, they could be held in the form } \\
\text { of interest-bearing public bonds. }\end{array}$ \\
\hline 1997 & 1.447 & $\begin{array}{l}\text { In September, the BOT reduced the liquidity requirement ratio on total deposits from } 7 \% \text { to } 6 \% \text {. } \\
\text { For finance companies the liquidity requirement on total domestic and foreign borrowing was } \\
\text { reduced from } 7 \% \text { to } 6 \% \text {. This was also applied to non-resident deposits, or foreign borrowing } \\
\text { with maturity of less than one year. }\end{array}$ \\
\hline 1999 & 1.440 & $\begin{array}{l}\text { The BOT announced new rules on liquidity reserve requirement composition and procedure, } \\
\text { but not changes in rates. }\end{array}$ \\
\hline 2000 & 1.440 & No changes. \\
\hline
\end{tabular}

Source: Annual Reports of the Bank of Thailand. 


\section{ApPendix 4. Algorithm to Track the Evolution OF Bank OWNership}

This Appendix describes the algorithm used to reconstruct the evolution of bank ownership. Ideally, the objective is to identify foreign institutions involved in retail banking and with access to upstream financing from their mother banks. ${ }^{13}$ This is the case of branches of foreign banks, which can obtain resources from their mother institutions as needed. This may also be the case of subsidiaries of foreign banks, although the availability of upstream resources in this case is not guaranteed. In this paper a bank is considered "foreign" if it is a branch of a bank incorporated in a foreign country, or if it has shareholders settled in a foreign country, holding together at least 51 percent of the bank capital.

The above operational definition was applied in four steps. First, the Bankscope search engine was used to identify subsidiaries of banks from OECD countries. Those with more than 51 percent of ownership in the hands of foreign banks were selected. This search identified 304 banks at least partially owned by banks from OECD countries. Of those, 189 had more than 51 percent in the hands of banks headquartered in OECD countries. Second, to verify the above list, the search engine of Bankscope was used to identify the shareholders of the sampled banks. Specifically, banks with shareholders settled in OECD countries, holding together at least 51 percent of the bank capital were filtered. In cases with no available information on percentage ownership, banks with one or more shareholders from OECD countries, and with local shareholders holding together less than 50 percent of the bank's

\footnotetext{
${ }^{13}$ In practice, both the nature of the services provided by foreign banks, and their access to upstream resources, depend on the institutional modality of entry. The most commonly used are representative offices, branches, subsidiaries, and joint ventures.
} 
capital, were also selected. These filtering criteria produced 313 cases. Of those, 171 were common to the 189 mentioned above, and taken as foreign banks without further check. The remaining 18 were checked individually by looking at their web pages. All of them were included in the final list of foreign banks.

Third, as the information on ownership is not available for all the banks included in the Bankscope database, a list of banks with unknown dependence was produced. The search matched 801 banks. This information was crossed out with a list of transnational banks headquartered in OECD countries or the Cayman Islands, gathered from the web site www.transnationale.org. In addition, the list of banks in the sample was intersected with the lists of foreign banks available from the Central Banks' web pages of Hong Kong, Brazil, Singapore, and Thailand. On a case-by-case basis, 168 additional branches of foreign banks were also identified.

The list produced by the above criteria provides information on ownership as of end-2000 (in some cases end-2001). In the fourth step, to obtain chronological information on changes in ownership throughout the period, the sample of banks was intersected with a comprehensive list of mergers and acquisitions targeting financial institutions in the sampled countries taken from the SDC Platinum database. Specifically, the list includes all transactions announced between January 1, 1985 and December 31, 2000, targeting institutions classified under industrial (SIC) codes $6000,6081,6029,6021$, and 6712 (to be on the safe side, these codes include a broad category of target financial institutions). The search produced 1,227 transactions involving 804 target institutions. Of those, 404 were matched with the sample of banks. In order to track acquisitions by financial institutions exclusively, the list ignored 
operations were the acquirers and their nationalities were unknown. Using the description of each operation, nine categories were created, indicating the nationality of the buyer (foreign OECD, foreign non-OECD, government, domestic resident), and the resulting ownership position after the transaction (public, domestic, foreign OECD, and foreign non-OECD). ${ }^{14}$ With the help of this code, it was possible to replicate the evolution of bank ownership throughout the period. In total, the algorithm identified 58 institutions changing ownership.

\footnotetext{
${ }^{14}$ In cases where the acquirer is a public company (there are several cases involving government-owned companies based in China), we classify the acquirer as government.
} 